\title{
A Study of Five Historic Cemeteries at Choke Canyon Reservoir, Live Oak and McMullen Counties
}

Anne A. Fox

Center for Archaeological Research

Follow this and additional works at: https://scholarworks.sfasu.edu/ita

Part of the American Material Culture Commons, Archaeological Anthropology Commons, Environmental Studies Commons, Other American Studies Commons, Other Arts and Humanities Commons, Other History of Art, Architecture, and Archaeology Commons, and the United States History Commons

Tell us how this article helped you.

This Article is brought to you for free and open access by the Center for Regional Heritage Research at SFA ScholarWorks. It has been accepted for inclusion in Index of Texas Archaeology: Open Access Gray Literature from the Lone Star State by an authorized editor of SFA ScholarWorks. For more information, please contact cdsscholarworks@sfasu.edu. 
A Study of Five Historic Cemeteries at Choke Canyon Reservoir, Live Oak and McMullen Counties

\section{Creative Commons License}

\section{(c) (1) \&}

This work is licensed under a Creative Commons Attribution-NonCommercial 4.0 International License 


\section{A Study of Five Historic Cemeteries at Choke Canyon Reservoir, Live Oak and McMullen Counties, Texas}

Anne A. Fox

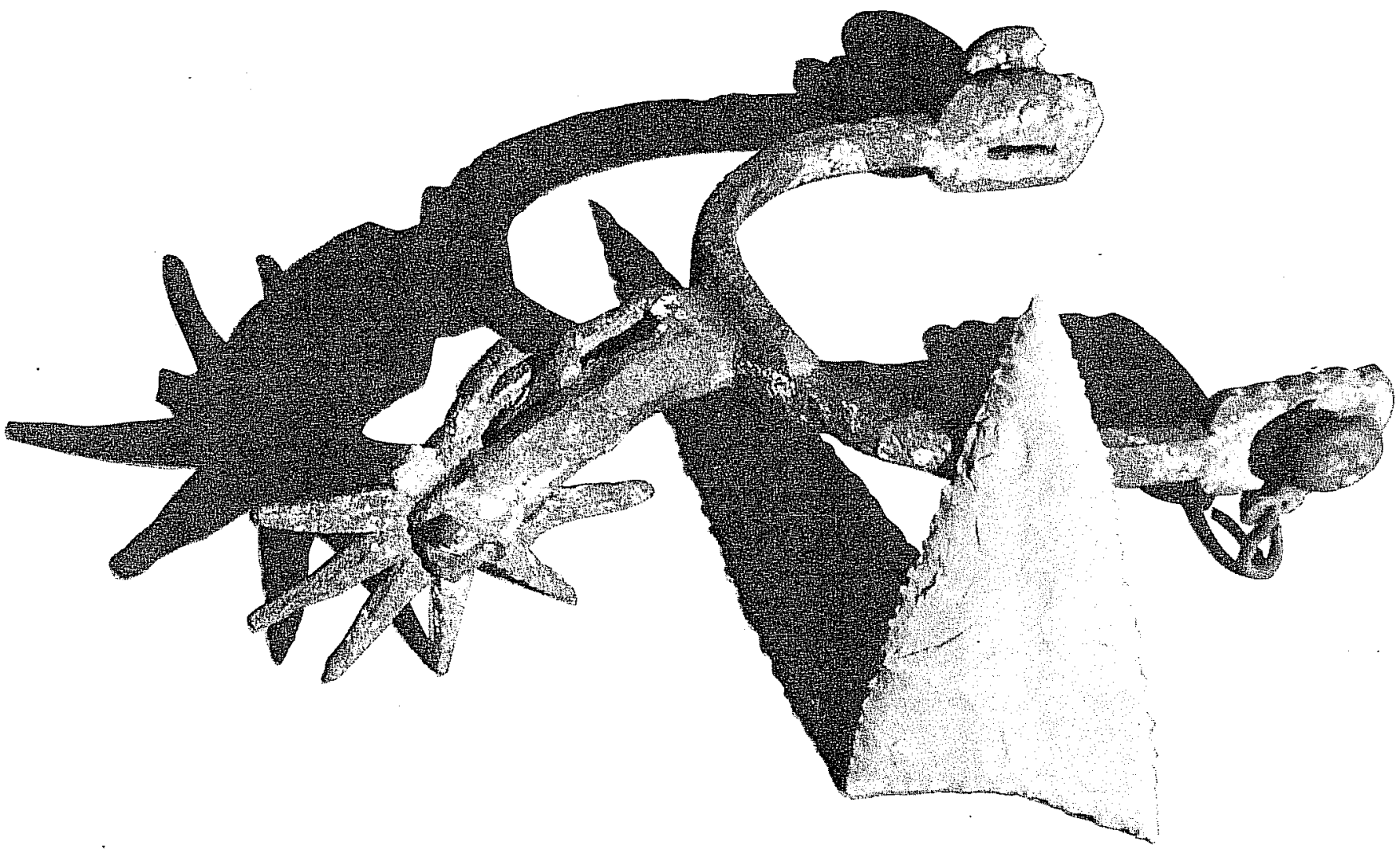

Center for Archaeological Research

The University of Texas at San Antonio

Choke Canyon Series: Volume 9 



\section{Center for Archaeological Research \\ The University of Texas at San Antonio \\ 78285}

Thomas R. Hester, Director

Volumes in the Choke Canyon Series.

Volume 1 Historic Indian Groups of the Choke Canyon Reservoir and Surrounding Area, Southern Texas. By T. N. Campbe11 and T. J. Campbe11, 1981.

Volume 2 Part I: Historical Resources of the Choke Canyon Reservoir Area in McMullen and Live Oak Counties, Texas. By Dianna Everett.

Part II: Historical Archaeological Resources of the Choke Canyon Reservoir Area in McMullen and Live Oak Counties, Texas. By Philip A. Bandy, 1981.

Volume 3 An Archaeological Survey of a Portion of the Choke Canyon Reservoir Area in McMullen and Live Oak Counties, Texas. By Alston V. Thoms, John L. Montgomery, and A7ice W. Portnoy. 1981.

Volume 4 The 1979 Archaeological Survey of Portions of the Choke Canyon Reservoir in Live Oak and McMullen Counties, Texas. By Erwin Roemer, Jr., 1981.

Volume 5 Archaeological Investigations at Choke Canyon Reservoir, South Texas: The Phase I Findings. By Grant D. Ha 17, Stephen L. Black, and Carol Graves, 1982.

Volume $6 \quad$ Archaeological Testing and Collecting at Choke Canyon Reservoir, Nueces River Project, Texas. By Carol S. Weed and Harry J. Shafer, 1981.

Volume 7 Excavations at 47 LK 67, A Prehistoric Site in the Choke Canyon Reservoir, South Texas. By Kenneth M. Brown, Daniel R. Potter, Grant D. Ha11, and Stephen L. Black, 1982.

Volume 8 Excavations at Sites 41 LK $31 / 32$ and 41 LK 202 in the Choke Canyon Reservoir, South Texas. By Robert F. Scott IV and Danie1 E. Fox, 1982.

Volume 9 A Study of Five Historic Cemeteries at Choke Canyon Reservoir, Live Oak and McMullen Counties, Texas. By Anne A. Fox, 1984. 



\section{A Study of Five Historic Cemeteries at Choke Canyon Reservoir, Live Oak and McMullen Counties, \\ Texas}

Anne A. Fox

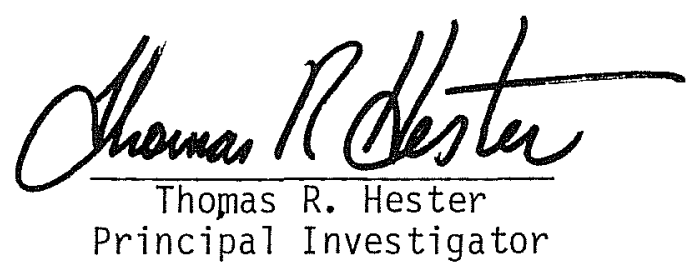

Center for Archaeological Research

The University of Texas at San Antonio

Choke Canyon Series: Volume 9 
PREFACE

These people of the past, our ancestors, gave us our customs, beliefs, language, even 1 ife itself; and now their giving continues through information encoded in their bones, promising us a better understanding of the past, the present, and the future.

Douglas Ubelaker, 1980

In 1981, as the final stages of construction on the Choke Canyon Reservoir were being completed by the United States Bureau of Reclamation, several late 19th-century graves and cemeteries had to be relocated in compliance with State law. Archaeologists have not been traditionally involved in such activities; this is the domain of the mortician, who follows certain standard procedures in exhumation and reburial. In the case of a later cemetery at the town of Calliham, in use until recent years and maintained by local citizens, the relocation of graves was handled entirely by a funeral home under contract with the Bureau of Reclamation.

However, out in the mesquite thickets, in areas once the site of frontier settlement, there were graves and cemeteries long forgotten by most of the modern residents of Live Oak and McMullen Counties. To be sure, some families still knew of ancestors buried in these locales. But for the most part, the graves were untended, had suffered the ravages of time and of vandals (who had destroyed or stolen stone grave markers), and, in some cases, the actual number of burials at a particular cemetery was far from certain. Therefore, the Bureau of Reclamation decided to involve archaeologists, both from their Amarillo office and from the Center for Archaeological Research at The University of Texas at San Antonio, to aid in the relocation of these interments. The field work and subsequent historical and laboratory research carried out in this effort is reported in this monograph.

As it turned out, the participation of archaeologists in the cemetery relocation project was critical. The skills of the archaeologist were important in detecting grave pit outlines in these old cemeteries where simple wooden coffins had rotted away. The observations of a physical anthropologist on the team were of great relevance in ascertaining the sex and age of the remains from graves which were either initially unknown or for which the tombstones had been removed or destroyed. In this way, the identity of persons buried in some of the graves could be established; the memories of family members were sometimes incorrect or in other cases, grave markers had been inadvertently switched over the years.

There was a certain amount of conflict at first between archaeologist and mortician: whose business was this anyway? However, as Anne Fox describes in this monograph, a working arrangement was eventually established. It further developed that the presence and interest of the archaeological crew 
served to demonstrate a sensitivity, on the part of the government, that was appreciated by the family members who gathered to watch the grave removals.

The cemeteries described here have, after all, a niche in the history of the development of this region. Through the scientifically oriented treatment of the burials, the historical research that preceded and followed the relocation project, and the analysis of skeletal and material culture remains from the graves, an important set of data can now be added to early history of this area of southern Texas.

Thomas R. Hester

Principal Investigator 


\section{ABSTRACT}

From December 1981 to November 1982, archaeologists from the Center for Archaeological Research, The University of Texas at San Antonio, and the U.S. Bureau of Reclamation aided in relocation of five historic cemeteries at Choke Canyon Reservoir in Live Oak and McMullen Counties. Thirty-four graves were located, uncovered, recorded, and removed to other cemeteries. During the process, descendants of the families involved provided valuable information on grave locations and identification. Observations were made which will be useful to other archaeologists engaged in similar projects. Information was compiled on customs and traditions of the people of the area in respect to death and burial. 

TABLE OF CONTENTS

PREFACE (Thomas R. Hester) ................ i i ABSTRACT ................................ $i{ }_{i}$

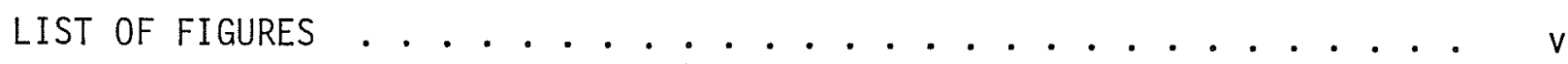
LIST OF TABLES . . . . . . . . . . . . . . . . . . . . vi ACKNOWLEDGMENTS ...................................... vii INTRODUCTION . . . . . . . . . . . . . . . . . . . . 1

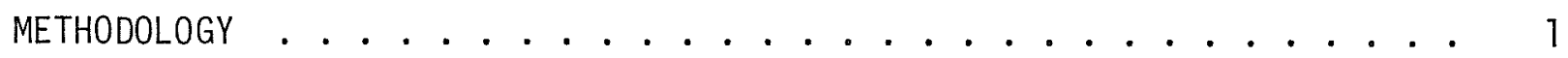
HISTORICAL BACKGROUND . . . . . . . . . . . . . . . 2 ARCHAEOLOGICAL BACKGROUND ......................... 4

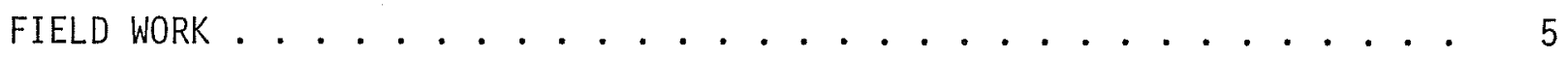
Johnston Cemetery $(41$ LK 73) . . . . . . . . . . . 5 Morris/Taylor Burials (41 MC 6) .............. 9 Morgan Cemetery (41 MC 4) . . . . . . . . . . . . . . 14 Yarbrough Bend Cemetery (41 MC 18) . . . . . . . . . . 21 Byrne Cemetery . . . . . . . . . . . . . . . . 31

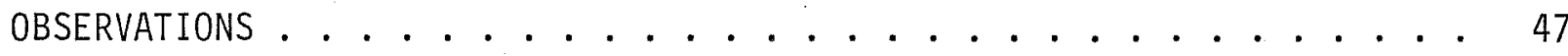

Cemeteries ................... . . 47

Graves ..................... . . . 49

orientation .................... . . 49

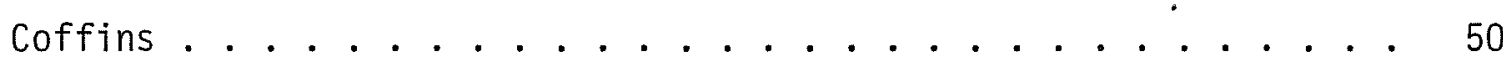

Grave Markers ................. . . 51

Fences .................... 52

Burial Customs ................ 52

Grave Inclusions in Yarbrough Bend ............. 53 SUMMARY AND CONCLUSIONS ................... 53

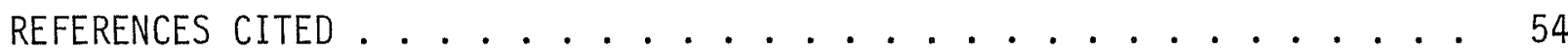


APPENDIX I. Identification of Wood Samples from Two Cemeteries in the Choke Canyon Reservoir (George R. Aliaga) . . . . . . 59

APPENDIX II. Analys is of Religious Medal (Richard E. Ahlborn) . . . . . 69

APPENDIX III. Glossary . . . . . . . . . . . . 70

\section{LIST OF FIGURES}

1. Map of Reservoir Showing Locations of Cemeteries . . . . . . . . . 3

2. Map of Johnston Cemetery ................... . 6

3. Views of Johnston Cemetery .................. 7

4. Map of Taylor/Morris Burials . . . . . . . . . . . 10

5. Photographs of Morris/Taylor Burials . . . . . . . . . . 11

6. Details of Morris/Taylor Burials . . . . . . . . . . . 13

7. Map of Morgan Cemetery . . . . . . . . . . . . . 16

8. Photographs of Morgan Cemetery . . . . . . . . . . . . . . 17

9. View and Details of Morgan Burials ............... 19

10. Sketch of Yarbrough Cemetery Gravestones . . . . . . . . . . . . 23

11. Map of Yarbrough Cemetery .................. 25

12. Photographs of Graves . . . . . . . . . . . . . . . 26

13. Clearing Cemetery Before Excavation . . . . . . . . . . . . 27

14. Map of Byrne Cemetery ... . . . . . . . . . . . . 33

15. Views of Byrne Cemetery Before Excavation . . . . . . . . . 35

16. Details of Grave 1................. . . 36

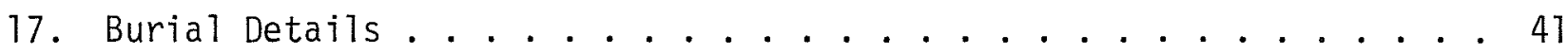

18. Tilden Cemeteries ......................... 48

19. A Transverse Surface View of a Wood Sample from Byrne Cemetery, Grave 2; X700 . . . . . . . . . . . . . 6 63

20. A Transverse Surface View of a Wood Sample from Byrne Cemetery, Grave 2; X100 ................. . . 65 
21. A Transverse Surface View of a Wood Sample from Yarbrough Cemetery, Grave 1; X150 ............. . 66

\section{LIST OF TABLES}

1. Summary of Data on Yarbrough and Byrne Cemetery Burials . . . . . 46

2. Identification of Wood Samples . . . . . . . . . . . 62 



\section{ACKNOWLEDGMENTS}

We wish to thank Harold Pendleton and Ernie Enlow at the Three Rivers office of the U.S. Bureau of Reclamation for their part in organizing and supervising the cemetery relocations. USBR archaeologists Steve Ireland, Meeks Etchieson, and Bobbie Ferguson spent many hours working beside those of us from the Center for Archaeological Research in uncovering and recording burials, for which we are grateful also. Thanks as well to archaeologists Patience Patterson from the Texas Historical Commission, Mary Jane McReynolds from the Texas Archeological Survey, and to Janet Stock from the Center for Archaeological Research for their help.

Morticians Charles and Pat Hurley from Pleasanton and David Stewart from the Eckols Funeral Home in Kenedy deserve special recognition for their patience with what must have often been an annoying and incomprehensible attention to detail displayed by the archaeologists, and for their interested and enthusiastic cooperation once we reached an understanding of how to proceed.

To all the numerous descendants of the deceased who came out to the cemeteries we owe a real debt of gratitude. The information they provided has been essential in interpreting what we found, and their enthusiastic interest in and support for what we were trying to achieve was most heartening. People who were particularly helpful in providing information were The lma Bomar, Thelma Ritter, Carmen Pierce, Clara Dilworth Wyatt, Helen and Henry Beard, and J. R. "Rocky" Henry.

We are grateful to botanists Dr. Richard Holloway and George Aliaga of Texas A\&M University for arranging for the analysis of the wood samples. Richard Ahlborn took time from his busy schedule at the Smithsonian Institution to provide additional information on the religious medal buried with Miss Eliza Byrne, and we thank him.

A special note of thanks goes to $D r$. Thomas R. Hester who served as principal investigator for the project and Grant D. Hall as co-principal investigator.

The author would like to add a personal note of thanks to archaeologists Grant Ha11, who did the mapping and made many of the arrangements for the project, and Al Wesolowsky for his yoeman service as physical anthropologist and photographer. A large vote of thanks, above all, to the U.S. Bureau of Reclamation for allowing us to proceed with this rather unusual project. We hope they will feel that it was justified by the amount of important information recovered and the enthusiastic support we received from the descendants of the people buried in Yarbrough Bend. 


\section{INTRODUCTION}

Between December 1981 and November 1982, archaeologists from the Center for Archaeological Research (CAR), The University of Texas at San Antonio (UTSA), and the U.S. Bureau of Reclamation (USBR) monitored the relocation of five historic cemeteries at Choke Canyon Reservoir in Live Oak and McMullen Counties. Dr. Thomas R. Hester, Director of the CAR, was the principal investigator. Grant D. Ha11, Research Associate, was the co-principal investigator, and Anne A. Fox, Research Associate, was the field director. The cemeteries were to be moved as a part of the preparation for the filling of the recently built Choke Canyon Reservoir, since it had been determined that they would either be inundated or would be close to the shoreline and therefore accessible by boat. Experience had already shown that vandalism would probably soon eliminate a11 traces of the shoreline cemeteries, if they were not moved.

The archaeologists had requested the opportunity to participate in the cemetery relocation as a part of the CAR's ongoing study of historic sites within the Choke Canyon Reservoir. It was expected that information could be gained about the lives of the families who inhabited the house sites within the reservoir through examining the family relationships and the burial practices represented in their cemeteries. Since al1 known descendants of the people buried there would be invited to be present, this would be an excellent opportunity to learn more about family histories and local customs. Research had already revealed that relatively little is known about burial customs in 19th-century south Texas. It was hoped that some definitive statements would result from this project on the attitudes of the late 19th-century inhabitants of Yarbrough Bend toward death and burial.

Unlike most other archaeological reports which deal with cemeteries, this one does not contain photographs of the uncovered burials. This was a conscious choice on our part, in deference to the feelings of descendants of these families. Each burial was fully documented photographically, and the photographs are on file at the Center for Archaeological Research.

\section{METHODOLOGY}

The activities of the archaeologists consisted of mapping each cemetery, photographing the cemetery before and during the removal of burials, recording all above-ground gravestones, fences, cairns, and other features, recording the dimensions and depths of grave pits, and the shapes and dimensions of the coffins. Wherever possible, the position, condition, age at the time of death, and sex of each individual were assessed and recorded, as well as any evident pathologies. Artifacts included in the coffin were recorded and photographed before being reinterred with the remains. Samples of coffin wood were, however, retained for analysis. Field notes, drawings, and photographic documentation are on file at the CAR-UTSA.

The archaeologists worked in close cooperation with the morticians who contracted to move the cemeteries, a separate contract being let for each site. During work at the first three cemeteries, a system of operation evolved that was mutually beneficial in obtaining the maximum amount of information within a reasonable time. 
A map of the visible graves in the cemetery was made first, using alidade and plane table. The mortician used a backhoe or Bobcat to remove the top three feet or more of overburden in a grave, stopping when the first evidence was seen of wood or coffin nails. The loose soil was carefully cleaned off to this level, and an archaeologist then uncovered the burial, leaving all bones and artifacts in place. The burial was photographed, the artifacts were removed and recorded, and an archaeologist who was also a physical anthropologist examined the burial, assessing whenever possible its age and sex, and noting any pathologies present. The bones from each burial were removed by the archaeologists to a separate cement or cardboard container, carefully identified by grave number with in the cemetery as recorded on the map, and by name where that was known. The dimensions and depth of the bottom of the coffin were recorded on the map. The burials were then reinterred in local cemeteries, according to the wishes of the surviving family members. Those whose identity was unknown were reburied in the New Calliham or Tilden Cemeteries.

Archaeologists who participated in the disinterments on a regular basis were Grant Hal1, Al Wesolowsky, and Anne Fox of the Center for Archaeological Research. Of this group, Wesolowsky is a physical anthropologist. Archaeologists Steve Ireland, Meeks Etchieson, and Bobbie Ferguson represented the Amari110 office of the USBR during the project. The local USBR coordinators on the project were Harold Pendleton and Ernie Enlow. Other individuals who participated are mentioned in specific cemetery discussions.

\section{HISTORICAL BACKGROUND}

The area with which we are concerned in this study is located along the Frio River in south-central Texas, between the present town of Tilden and the McMullen-Live Oak County line (Fig. 1). Most of the people whose graves were to be relocated formed a part of an early settlement which came to be called Yarbrough Bend.

The settlement took its name from John Yarbrough, who led the first group of settlers into the area. Many of this group were related by blood or by marriage, and those who were not, soon married into the other families until the entire community consisted of what might be termed one large extended family. These people are believed to have travelled from one state to another across the south, starting in the Carolinas and moving slowly, ever westward through Georgia, Alabama, Mississippi, Louisiana, and into east Texas, arriving there just before the Texas Revolution in 1836 (MCHBC n.d.:442). Individual family histories and census reports listing birthplaces of family members confirm our perception of this slow exodus. Other settlers in the general Tilden area appear to have detoured to Rockport and Lamar on the coast before continuing to the Frio River settlement. Building herds from the numerous wild cattle in the area, most of these families became stock raisers, squatting on land belonging to far-away owners who lived in San Antonio and points north, and who perhaps did not know or care that there were "tenants" on their land. 


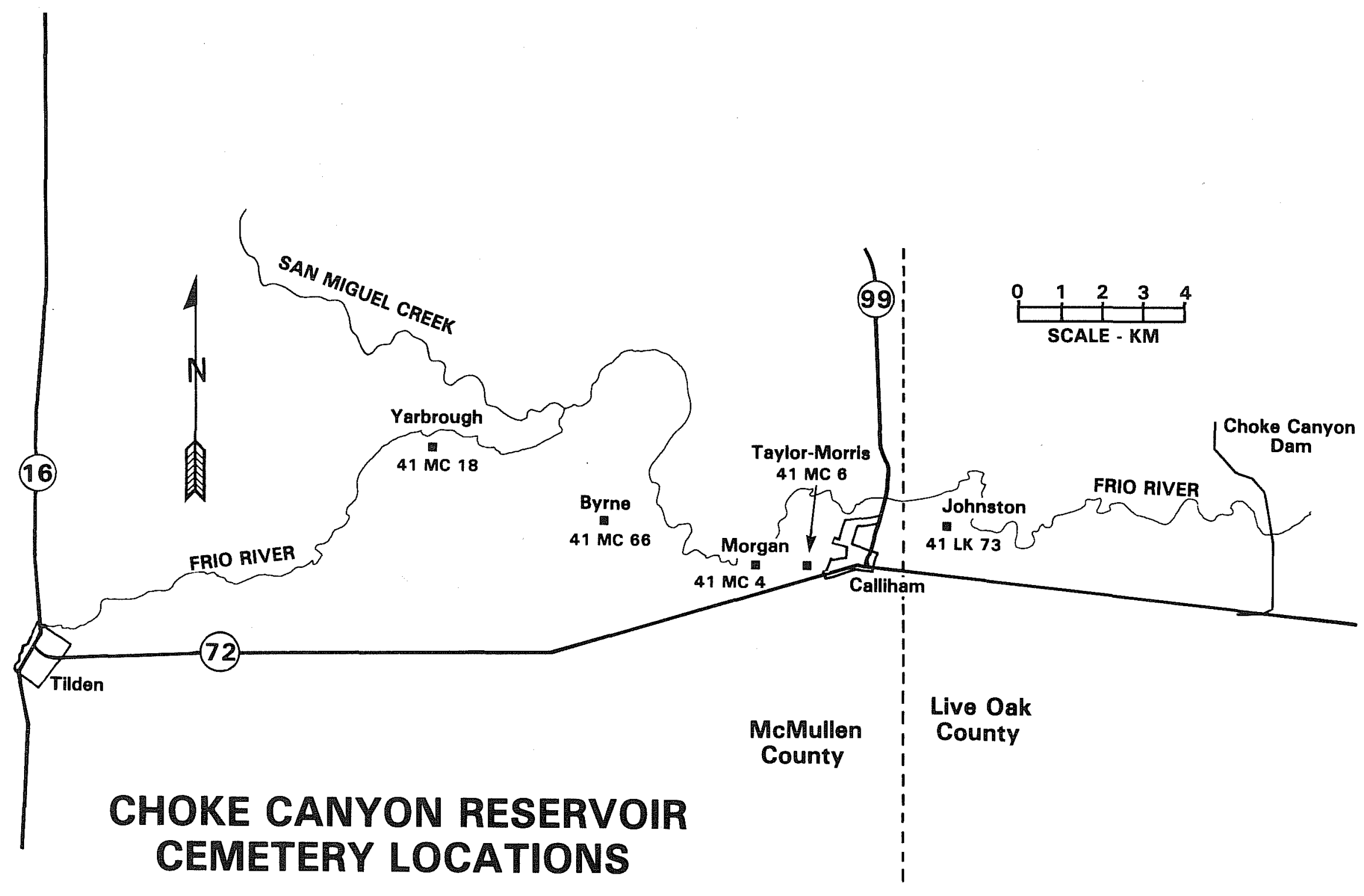

Figure 1. Map of Reservoir Showing Locations of Cemeteries. 
Small cabins were built, and 1 ife went on in the usual progression of birth and death. Living was hard, and there were few luxuries. Supplies had to be hauled from Oakville, 22 miles to the east, or San Antonio, 90 miles to the north. At first included in Live Oak County, the settlement eventually became a part of McMullen County when the last was officially organized in 1877, with Tilden as the county seat.

Fortunately, there was a doctor in the settlement. Dr. George A. Dilworth tended to the emergencies and the everyday problems of childbirth, illness, and injuries. Too often the doctor had to watch helplessly as his patients died and were buried in one of several small family cemeteries or in the town cemetery in Tilden.

Gradually as Tilden grew and fortunes changed, the residents of Yarbrough Bend moved on, moved into town, or bought land of their own elsewhere, and the settlement was abandoned. The small cabins crumbled to dust and piles of chimney stones. All that remained at the time of this study were a few late 19th-century farmhouses and traces of the cemeteries.

\section{ARCHAEOLOGICAL BACKGROUND}

Although Texas archaeologists have been excavating the burials of prehistoric people throughout the state for many years, relatively few historic cemetery excavations have taken place. A few historic Indian burials have been investigated (Newcomb 1958; Suhm 1962; Word and Fox 1975). Burials have also been excavated in connection with archaeological investigations at 18th-century Spanish sites (Schuetz 1968; Gilmore 1969). The author participated in excavations in the floor of the chapel at Mission San Juan Capistrano in 1969 (Schuetz 1974) which was one of the first excavations of 19th-century burials in the literature for Texas. Mid-19th-century burials disinterred in Fayette County (Carter and Ragsdale 1976), at the battle field of Resaca de la Palma near Brownsville (Collins, Hester, and Ellezy n.d.), and the recording and removal by Mary Jane McReynolds (1981) of 22 burials in Laredo in 1980 are the only other such operations on record. We felt particularly fortunate that McReynolds was able to visit and help with the Byrne Cemetery excavations.

Ordinarily, when cemeteries must be moved an undertaker contracts to do the complete operation of opening the grave, removing the remains of the individual, and reburying them in another cemetery. This is not an unusual request, and both undertakers with whom we worked told of numerous such jobs they had done in the past.

The fact that archaeologists have not often participated in moving graves does not mean that they have had no interest in historical cemeteries. Numerous cemeteries have been studied, photographed, mapped, and analyzed by Texas archaeologists as historical and anthropological studies (e.g., Fox 1976; Yates 1977). Terry Jordan (1982) has also done a useful study of cemeteries and burial practices. 
Studies of excavations of 19th-century cemeteries done elsewhere in the United States have been helpful in understanding what we found at Yarbrough Bend, particularly the study by Blakely and Beck (1982) who excavated a cemetery founded in 1850 in the city of Atlanta, Georgia.

\section{FIELD WORK}

Johnston Cemetery (41 LK 73)

The Johnston Cemetery was located on a low hilltop on the south side of the Frio River just east of the McMullen-Live Oak County line (Fig. 1). The site was recorded by the Texas Historical Commission survey team (Lynn, Fox, and O'Malley 1977:Table 22), and investigated in more detail during the Phase I investigations of the Choke Canyon Reservoir by the CAR-UTSA (Hall, Black, and Graves 1982:142-144). The cemetery was given the name of the family who most recently owned the property.

The cemetery consisted of a rectangular sandstone enclosure within which stood a crypt made of large sandstone slabs. The walls of the enclosure originally stood $1.2 \mathrm{~m}$ high, but at the time of the Phase I investigations portions of the north and west walls had collapsed. An entrance was located in the center of the south wall (Figs. 2 and 3,a). The rectangular enclosure, approximately five meters by six meters, was oriented with its larger dimension east to west. The crypt, located in its northwest quadrant, was ca. $1.9 \mathrm{~m}$ long and $90 \mathrm{~cm}$ wide (Fig. 3,b). The sides and top of the crypt consisted of large sandstone slabs varying from 10 to $20 \mathrm{~cm}$ thick (see Ha11, Black, and Graves 1982:142 for detailed descriptions). No gravestone or inscriptions were found to identify the occupant of the grave.

Although only one crypt was visible within the cemetery enclosure, local informants had indicated there might be as many as three interments there. No reliable information had been found on the identity of any of the burials, although several families had been suggested from which they might have come (Everett 1987:36; Lynn, Fox, and 0'Malley 1977:Table 22).

This was the first cemetery to be moved, and several important lessons were learned about the best method of doing this operation. Archaeologists Hall, Ireland, and Etchieson participated. The mortician was David Stewart from the Eckols Funeral Home in Kenedy, Texas, with an employee of the funeral home operating a backhoe. When the crew arrived on the site December 14, 1981, they discovered that a portion of the cemetery wall and the entire crypt had been completely removed by a bulldozer during borrow activity to the east of the site. There was no indication of the location of the grave associated with the crypt. Careful shovel scraping of the ground surface and passes with the mortician's front end loader soon revealed a rectangular outline in the soil $64 \mathrm{~cm}$ by $2.1 \mathrm{~m}$ in the area where the crypt had been located. The archaeologists and the mortician excavated the soil down to the skeletal remains, then removed the bones to a small wooden box. Fragments of the wooden coffin and a number of square nails were present, and a wood sample was retained for identification. The bones were well preserved, and the 

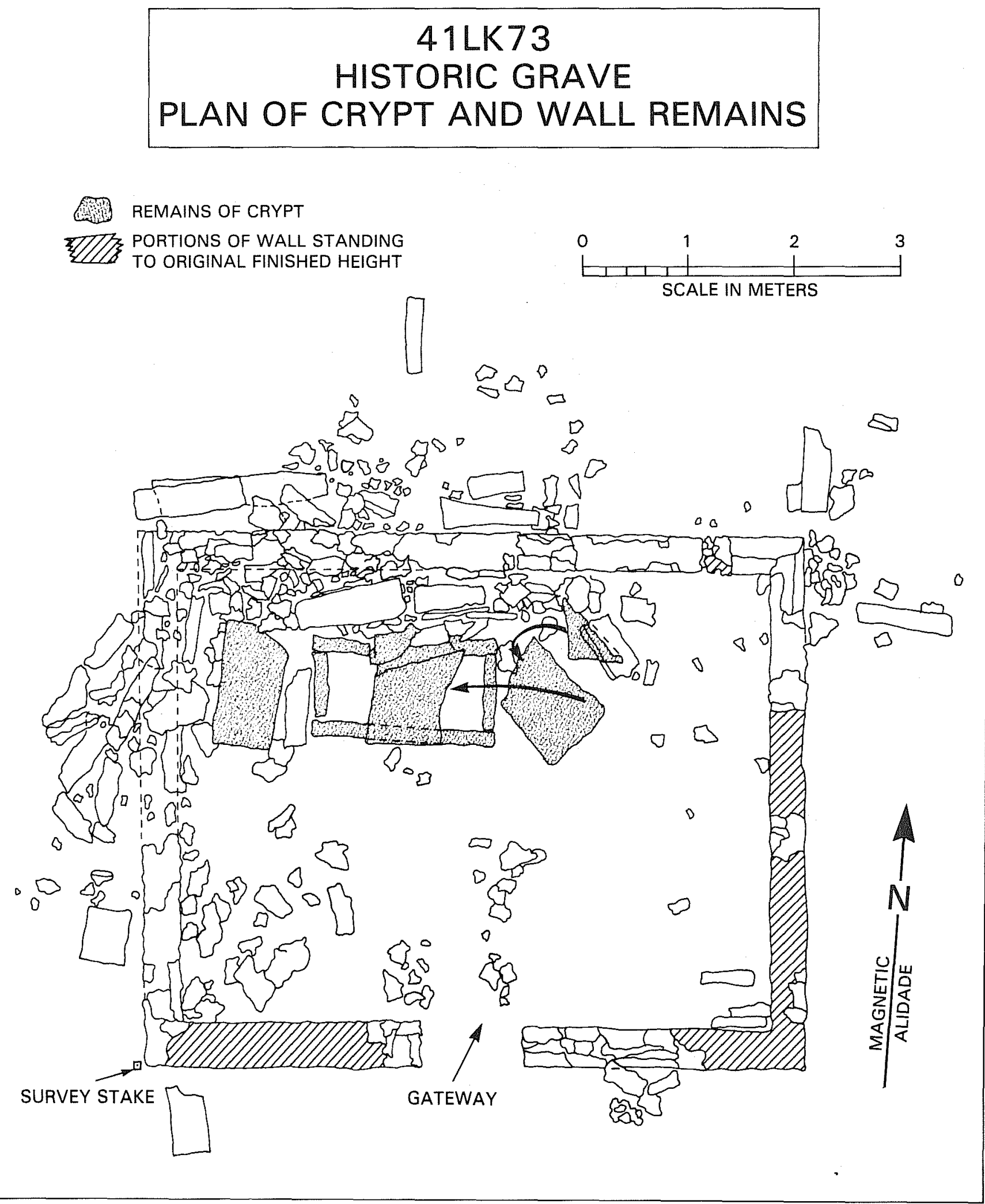

Figure 2. Map of Johnston Cemetery. 


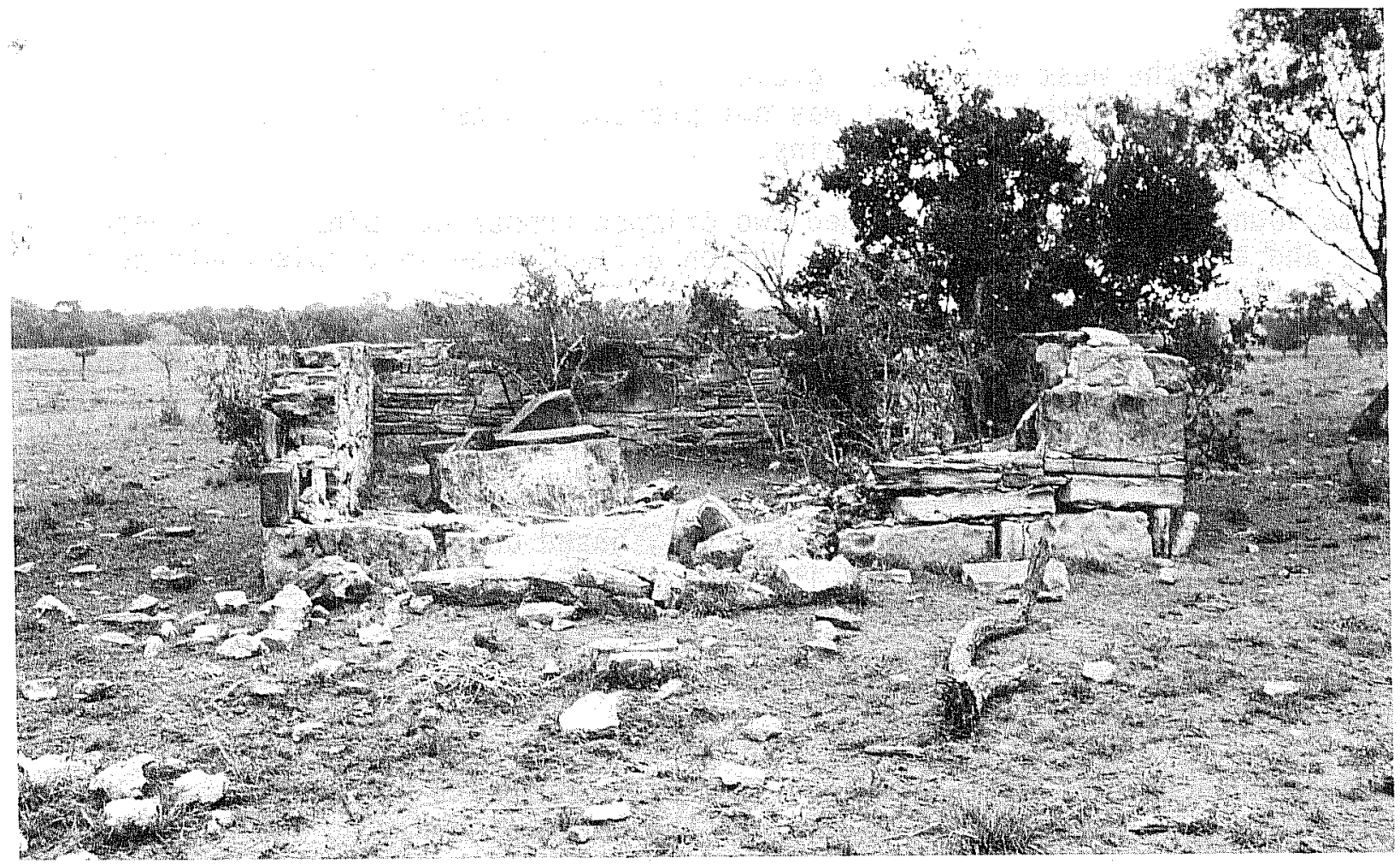

a

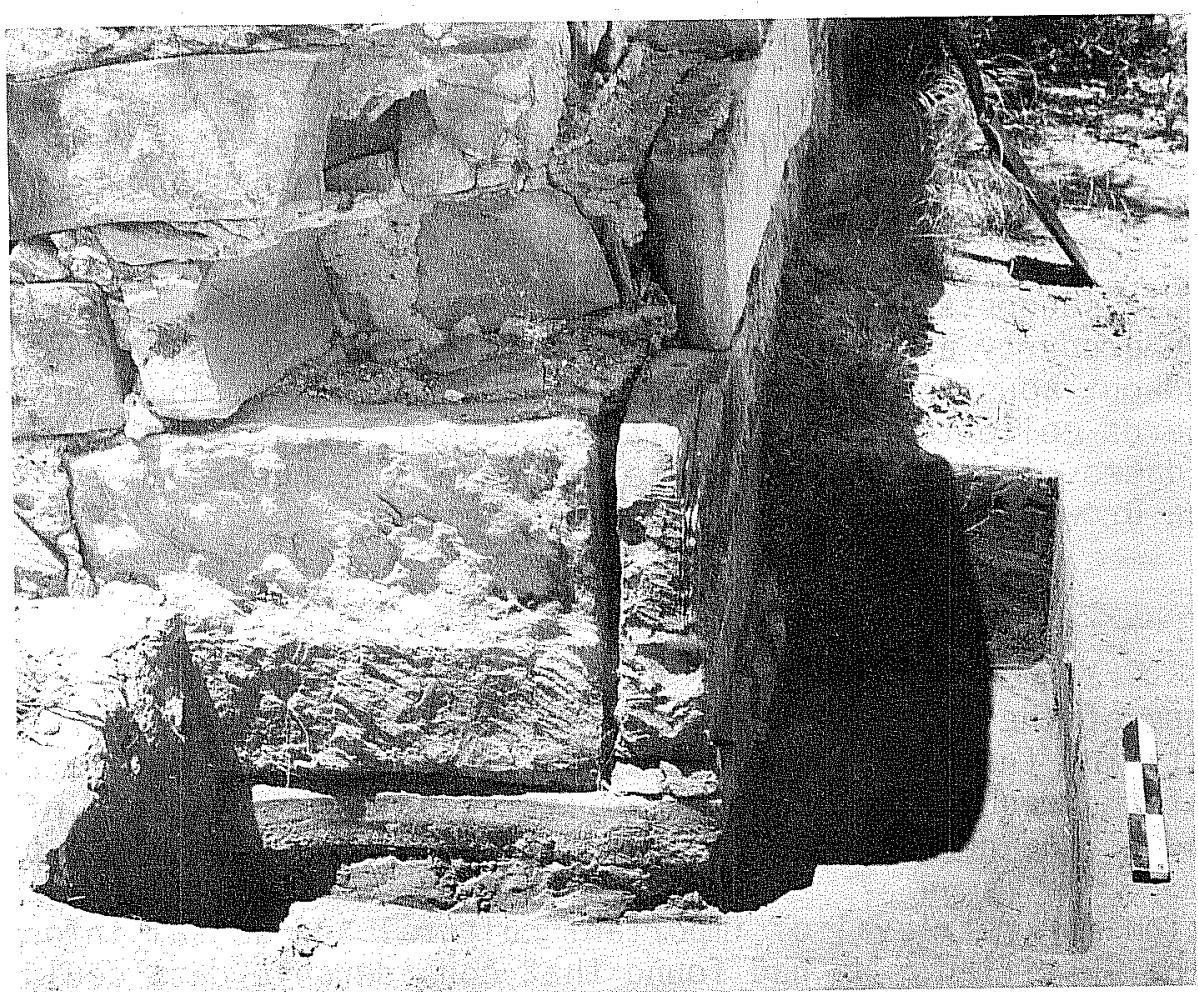

b

Figure 3. Views of Johnston Cemetery. a, view of cemetery before it was buildozed; b, construction technique and foundation details of wall around crypt. 
skul1 was at the west end of the grave. The right femur was $435 \mathrm{~mm}$ in length. Since a physical anthropologist was not present, no assessment of sex was made on the basis of the skeletal remains.

Items found in the burial included two crimped rubber hairpins in the head area and a three-hole, white glass button $8.5 \mathrm{~mm}$, made in a "piecrust" design, at the right shoulder.

The mortician excavated the remainder of the fill within the remains of the enclosure, and no additional burials were found. The box containing the remains was then taken to the New Calliham Cemetery to be reinterred. The entire operation took about five hours.

Judging from the stature of the individual, based on the femur measurement, and the nature of the inclusions it seems probable that this was an adult female. Crimped rubber hairpins were sold through the Montgomery Ward catalog of 1895 (Montgomery Ward \& Co. 1969:87), and sma11 piecrust buttons were popular between 1840 and 1880 (Schuetz 1969:40), so she appears to have been buried in the late 19 th century.

A house ruin (41 LK 73) located ca. 95 m east-southeast of the cemetery 1ikely related to this person. Excavations at the house site during the Phase I investigations (Ha11, Black, and Graves 1982:142-144) yielded an artifact inventory typical of a post-Civil War farmhouse.

The land on which the house and cemetery were located was known ca. 1900 as the "Cavitt Ranch," despite the fact that no one by that name had ever owned it. The house may have been built and occupied by William Cavitt, a local stockman, with or without the knowledge and consent of the absentee landowner (see Everett 1981:36). A bit farther to the west, in the Yarbrough Bend community, this circumstance was quite commonplace during the last half of the 19 th century.

Everett (ibid.) suggests that the cemetery may be related to the Brown family, who owned the property after 1890, or the Cavitt family. John Brown mentioned an old burned-out house on the property when he bought it, and a number of the glass sherds collected from the site have been burned. This, plus the approximate dates of the burial and the house ruin, suggests an earlier occupant than the Browns for the house and the cemetery.

\section{Discussion}

The experience at the Johnston Cemetery was useful preparation for the archaeologists and the USBR for the next burials. A better understanding was gained of the requirements and capabilities of the mortician, of the time required, and of the need for careful, informed observation of the proceedings.

The expectation for retrieval of important cultural and social information appeared to be justified. We had found that considerable data could be recovered by such work despite the fact that the burial remained anonymous. 
Morris/Taylor Burials (41 MC 6)

The Morris/Taylor gravesite was located just north of the old route of State Highway 72, half a mile west of the first townsite of Calliham (Fig. 1). The site was first recorded by the Texas Historical Commission survey team (Lynn, Fox, and O'Malley 1977:Table 22), and its history was reported by Everett (1981:48).

The graves were those of William B. Morris (1802-1869) and Martin Luther Taylor (1842-1869), according to the gravestone inscriptions. Published accounts by family members (MCHBC n.d.:124, 279; Day 1937:12-13) relate that Taylor and his father-in-law, Morris, were killed as a part of the Taylor-Sutton Feud that raged throughout south Texas in the 1860s and 1870s. There are numerous, differing accounts of the feud and how it started, but before it ended a hundred or more people had died, and circumstances required the Texas Rangers to put a stop to it.

The story recounted by Day (1937) had Morris and Taylor living on a ranch between Tilden and 0akville in April 1870. The gravestones indicate they died in 1869. Since Day's account was published almost 70 years later, a detai 1 such as the exact year of their deaths could have been distorted over the years. It is important, therefore, to consider very carefulty the source of any information gained from 1ocal tradition. Everett $(1981: 48)$ reported that the census report shows the widows of Morris and Taylor Tived together on San Miguel Creek, about four miles upstream from its confluence with the Frio River, in 1870, thereby supporting the 1869 date for the deaths.

Family tradition holds that Taylor was taken at gunpoint by members of the Sutton gang with the expressed intent to put him in the 0akville jail. Morris supposedly went along to make bond for Taylor (MCHBC n.d.:413). We do not know exactly what happened on the journey, but Morris and Taylor never reached Oakville; their bodies were found near the road and buried on the spot where they died. An early map (Corps of Engineers, U.S. Army 1920) shows the old road from Tilden to 0akville corresponding in this area to the old route of State Highway 72 , which was a short distance south of the site.

The burial site consisted of a low rubble cairn against which leaned two gravestones (Figs. 4 and 5,a). The cairn was roughly $2 \mathrm{~m}^{2}$, and the stones leaned against the west edge of the structure, their inscriptions facing toward the west. They had obviously been broken and removed from their original placement. At some time in the past each had been pressed into a crude wooden form lined with galvanized sheet metal that was partiarly filled with a thin cement grout, in order to restore their original appearance as much as possible.

On February 13, 1982, archaeologists Ha11, Wesolowsky, Fox, Ireland, and Etchieson met on the site with representatives of the USBR and morticians Charles and Pat Hurley from the Hurley Funeral Home in Pleasanton, along with several funeral home employees. In addition, a large group of Taylor descendants and other interested parties were present to observe the activities. It soon became apparent that the morticians had not been prepared to deal with 

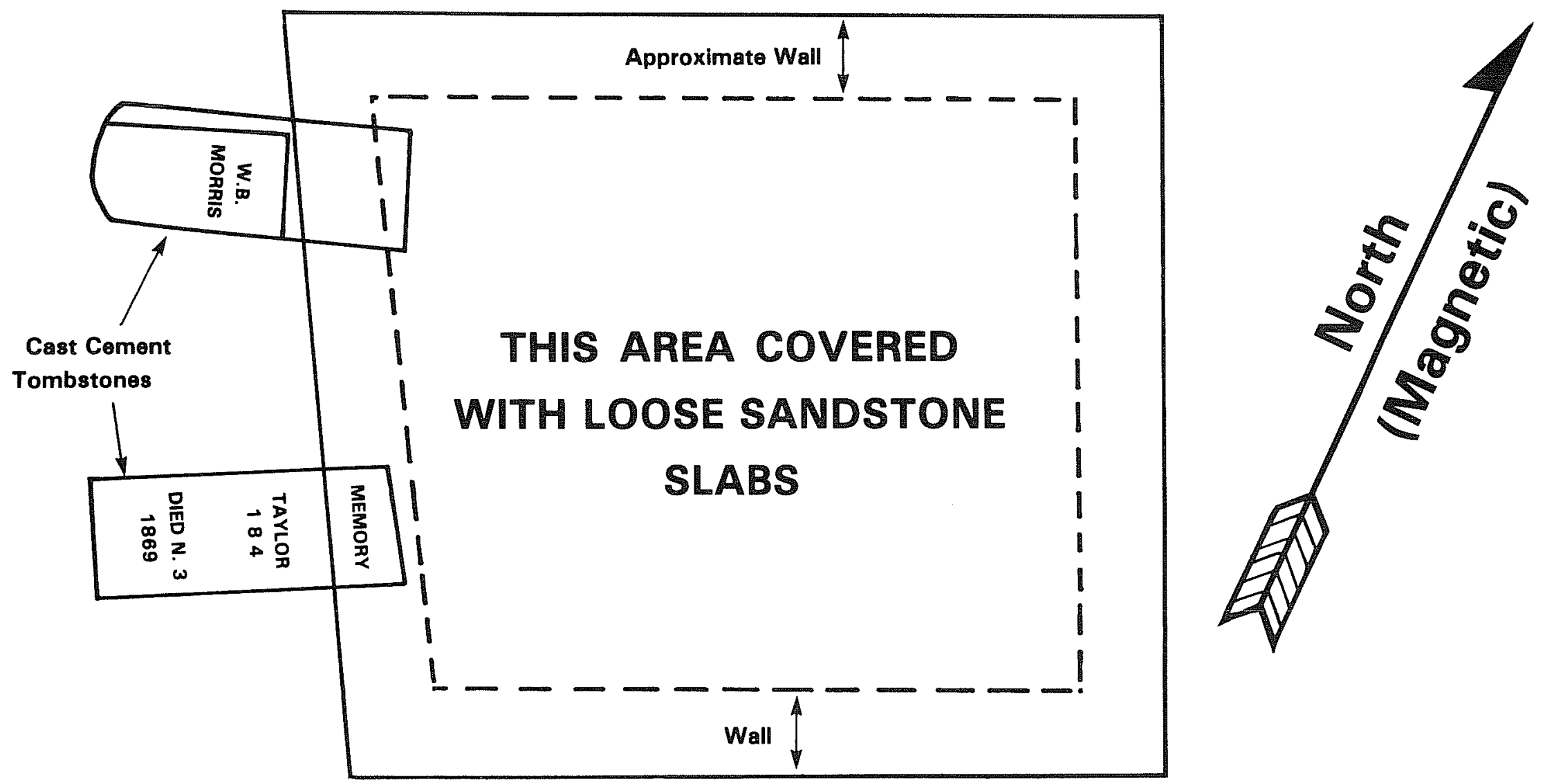

41 MC 6 - TAYLOR/MORRIS BURIALS PLAN MAP OF SANDSTONE CRYPT

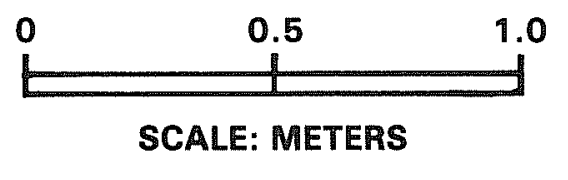

Figure 4. Map of Taylor/Morris Burials. 


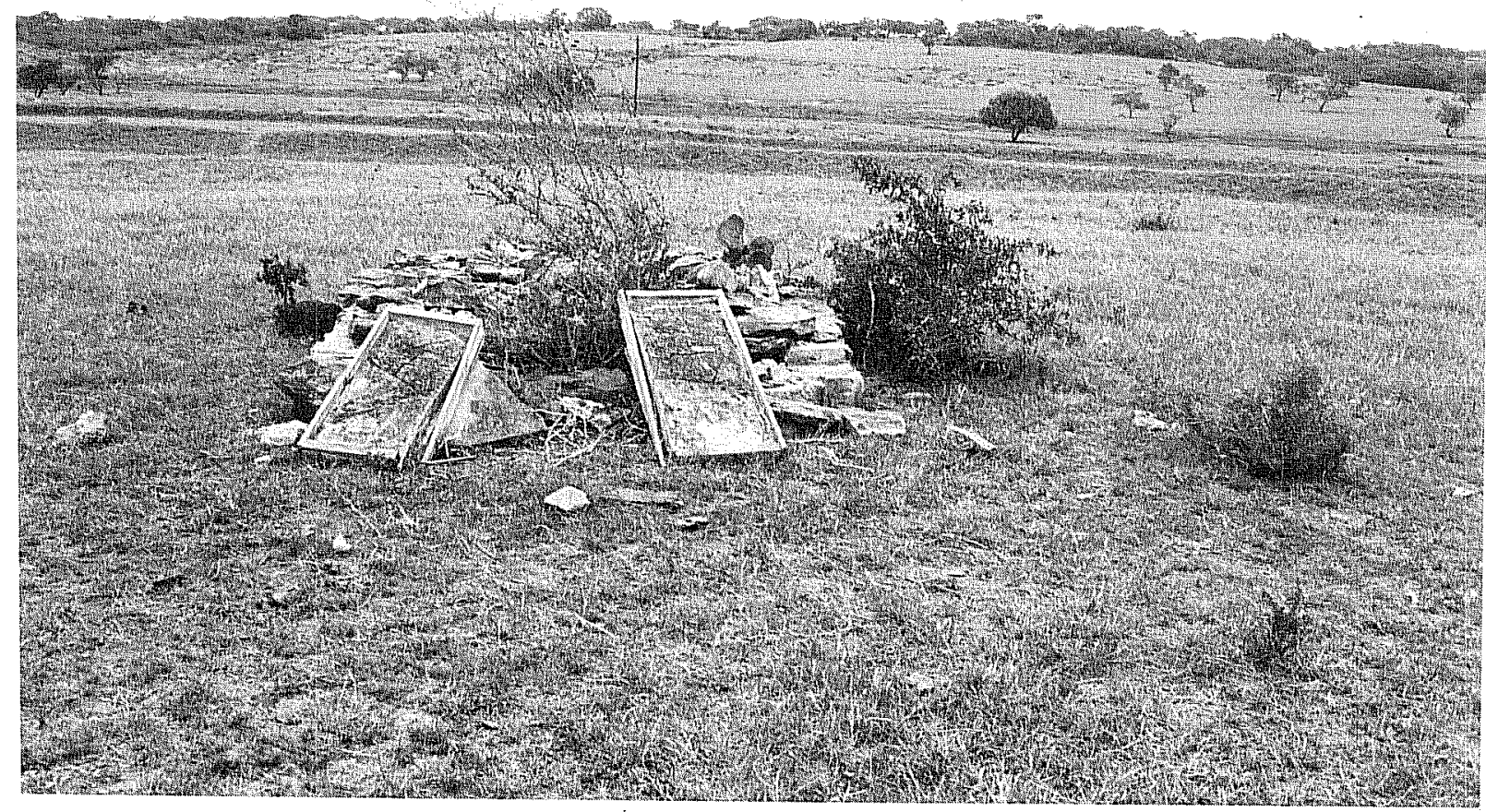

a

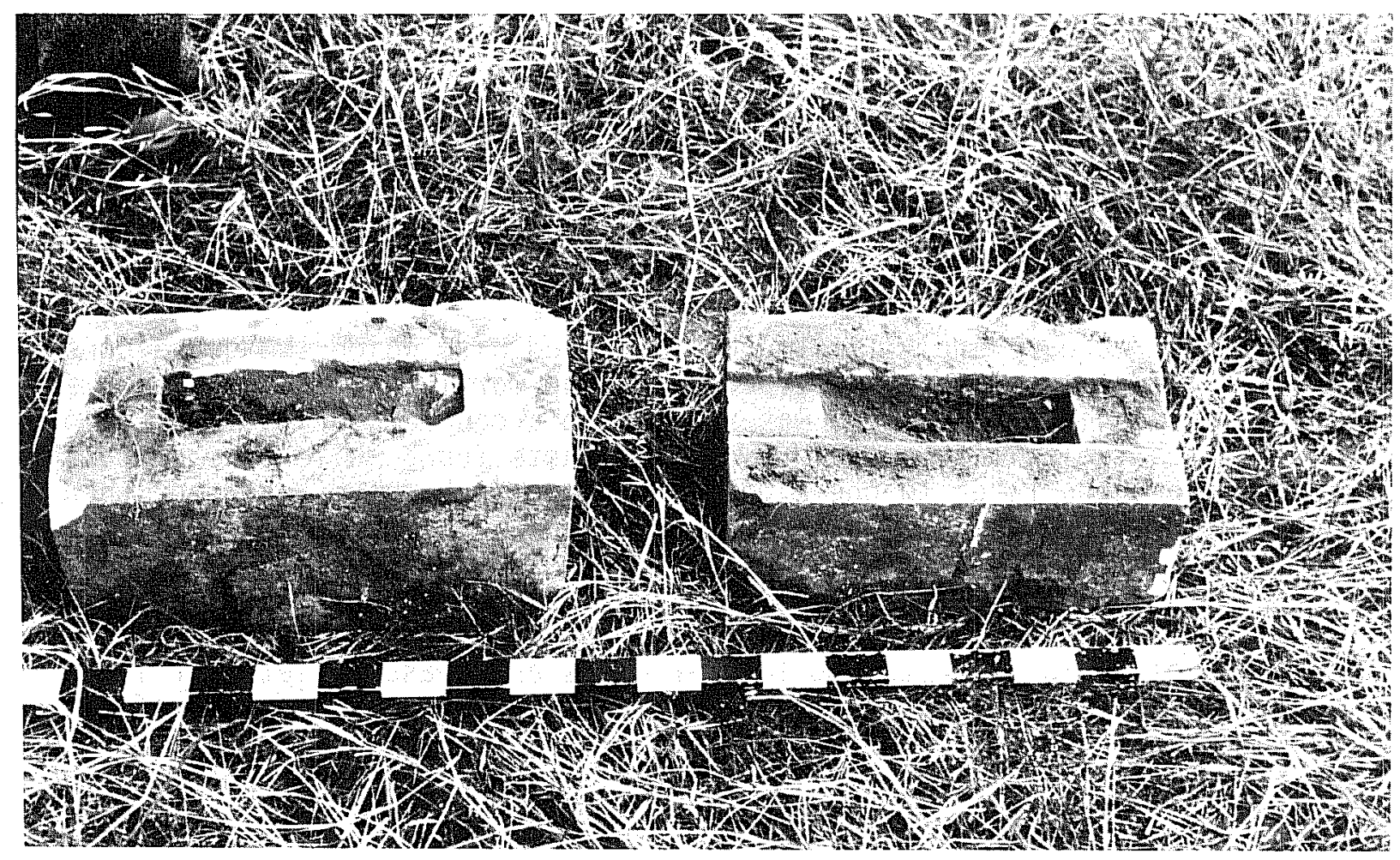

b

Figure 5. Photographs of Morris/Taylor Burials. a, view of Morris/Taylor cairn, looking east; b, plinths from graves. 
the combined pressures of the archaeologists' need for careful recording of the proceedings and the unbounded curiosity of the onlookers to see everything that transpired. Their understandable response was to get the job done as quickly as possible. Eventually a certain amount of rapport was established, however, and work was slowed down sufficiently to allow a minimal amount of recording and to improve public relations with the family members.

While the morticians were getting their equipment set up and deciding how to approach the task, the archaeologists made a measured drawing of the cairn (Fig. 4) and chalked the inscriptions on the gravestones for photographing (Fig. 6,c). A small Bobcat excavating machine with a bucket approximately two feet wide was used to help the morticians' workers remove the stones of the cairn in order to expose the tops of the graves for excavation. The gravestones were moved aside and later turned over to the descendants, who put them in the historical museum at Tilden.

While clearing off the surface, two socketed, white stone plinths, which once served as bases for the gravestones, were found buried just under the surface at the west edge of the cairn. They were of slightly different design, but the sockets were the same size in each one (Fig. 5,b). Unfortunately, we were not able to document the exact location of these objects since they were dislodged by the machine. An unshaped, flat stone in the cairn was found to bear the rude inscription "MORRIS." Apparently this was an earlier gravestone that was replaced by the ones shown in Figure 5,a. No similar Taylor stone was found.

Once the area had been cleared, the overburden in the southern grave tentatively identified from the location of the marker as that of Taylor, was removed by the Bobcat to about $76 \mathrm{~cm}$ below the ground surface. At this point, bone fragments were appearing, and the archaeologists requested that they be allowed into the grave to remove and record the bone and any related artifacts. The burial appeared to have been badly disturbed and fragmented in the past.

Observations were severely limited by the speed with which the grave contents were shoveled out under the instruction of the mortician, and no assessment of age was possible. A1l bone was removed to a concrete grave liner, along with some of the soil from the grave. Artifacts found while this operation was going on were taken to one side to be photographed and recorded, then were put into the grave liner with the burial.

At the east end of the grave, shoveling by the workers uncovered leather fragments. Once unearthed and brushed off, these were identified as parts of a pair of boots with stacked leather heels and brass eyelets for laces. The heels were attached to the soles with wooden pegs. Not enough of the leather was recovered to reconstruct the boots' design. In the area of the upper body were found four coat and one cuff-sized U.S. Army General Service buttons (Brinckerhoff 1972:5). This is particularly interesting in light of the fact that the Taylors were known for their Confederate sympathies. A plain, four-hole white glass button $\mathrm{ca} .1 \mathrm{~cm}$ in diameter was also recovered from this burial (Fig. 6,a). 


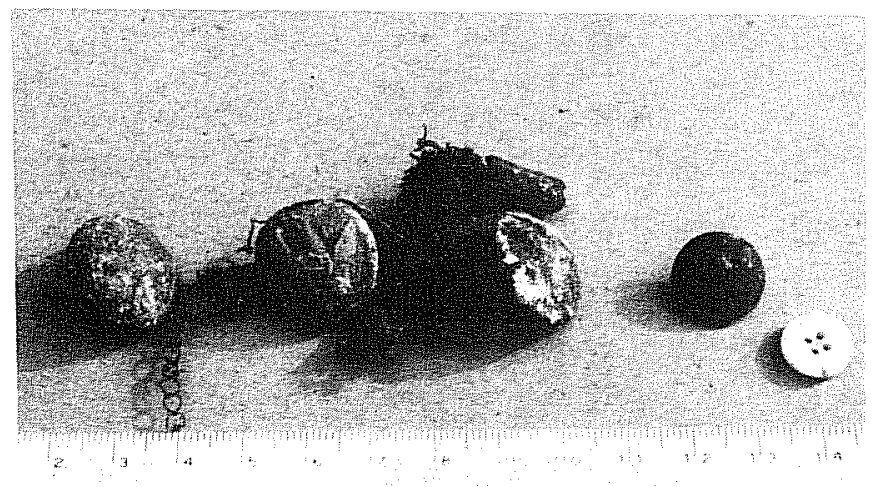

और

2

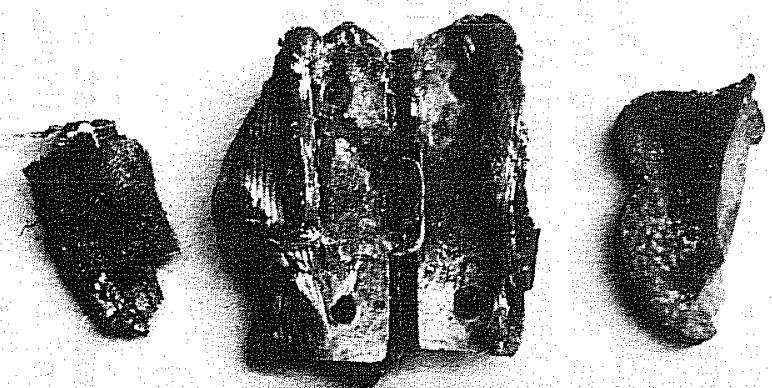

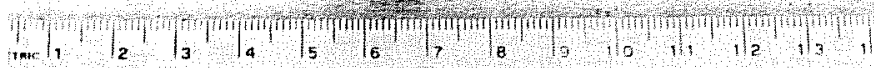

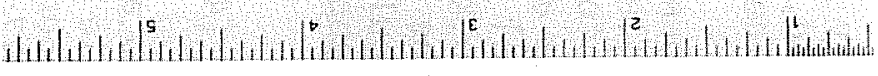

b

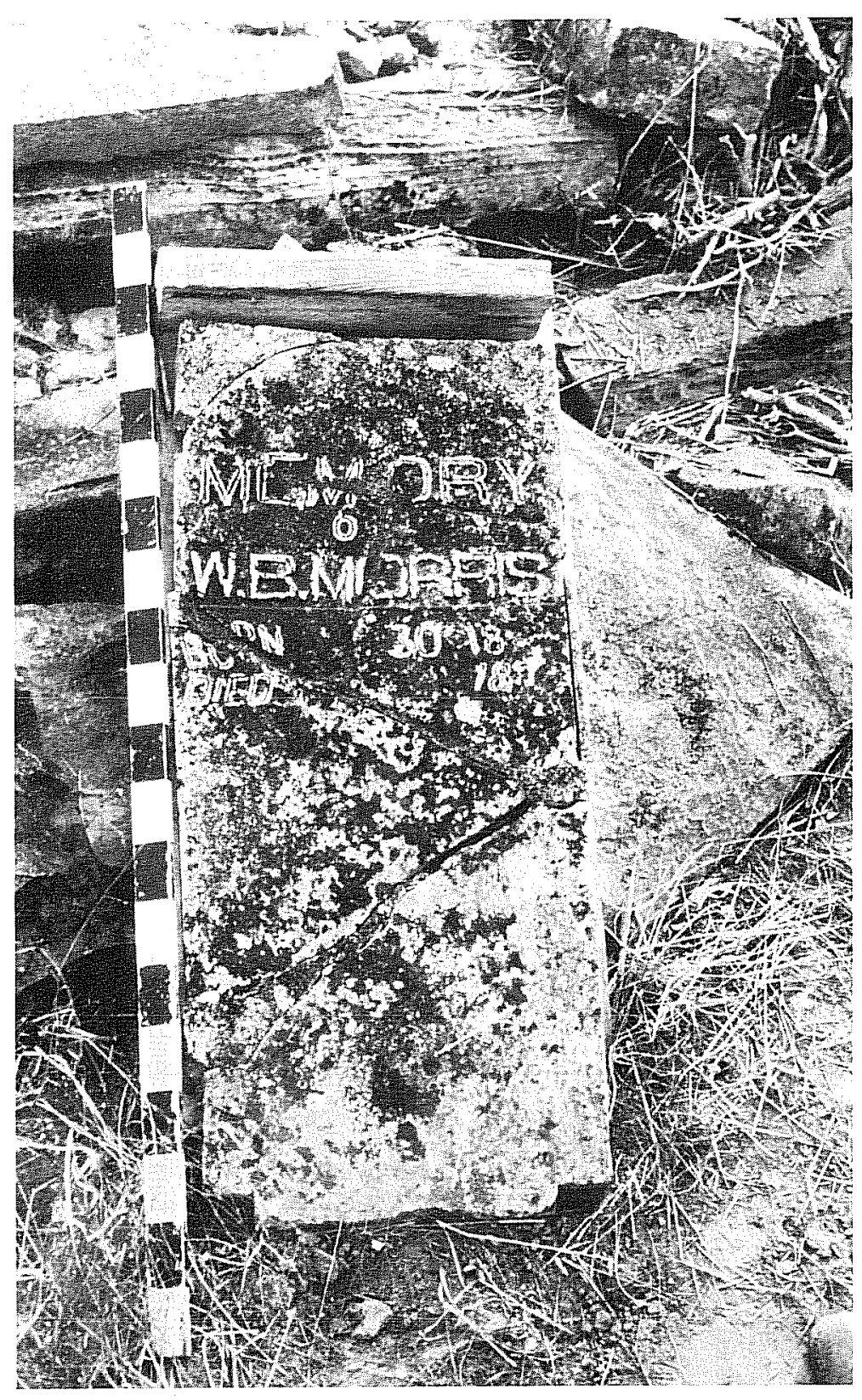

6

Figure 6. Details of Morris/Taylor Burials. a, buttons from Grave 1; b, buckle from Grave 2; c, W. B. Morris' gravestone. 
The burial to the north, tentatively identified as that of Morris, was then excavated in much the same manner. Here, again, the remains appeared disturbed, but we were not allowed time to determine the condition or age at death of the burial. As they were located, the bones were removed to a second concrete grave Tiner. Wesolowsky did observe that the bones were those of an adult and were more gracile than those of the first burial.

Artifacts recorded from this grave included a pocket knife, a 186? dime too corroded to date positively, a silver concha, and a brass buckle from some sort of webbed belt (Fig. 6,b). Small fragments of a number of different types of fabric were also preserved, probably by salts from the metal objects. The boots in this grave were well preserved and lifted out in one mass for examination and photography. They were remarkably similar in style and construction to government-issued brogans excavated at Fort Saunders, Wyoming (Brinckerhoff 1976:7).

The grave liners were mechanically hoisted onto a truck and taken to the Tilden Cemetery for reburial that afternoon. There was a brief ceremony attended by family members.

\section{Discussion}

Taylor and Morris were buried in a single grave with their heads to the west; the bottom of the grave was approximately $1.2 \mathrm{~m}$ below the surface. There were no signs of coffin nails or metal fixtures, and no fragments or stains of wood from coffins. The disturbed condition of the remains tends to confirm the local story that oil field workers once dug into the grave and removed a gun.

The identity of the individuals buried is confirmed by the presence of the grave markers and the nature of the artifacts. There was not, however, sufficient opportunity allowed the physical anthropologist to evaluate which person was the elder and, therefore, whether they are properly marked as they lie today in the Tilden Cemetery.

Despite the accounts which claim Morris and Taylor were shot to death (Day 1937:13), no bullets were found in the grave. Unfortunately, the operation was too hurried to allow careful examination of the remains for evidence of how they died. The absence of a coffin and of any evidence of preparation of the bodies for burial (viz., the clasp knife and coin from the northern burial suggest that the pockets of the deceased's clothing were not emptied) may be a reflection of the dangerous times and the circumstances under which the event occurred. It would be another 15 years before it was safe for a Taylor or a Sutton to move about freely in south Texas (Day 1937:7).

\section{Morgan Cemetery (41 MC 4)}

This site was located about a mile west of the old townsite of Calliham and a quarter of a mile north of $01 d$ State Highway 72, on the Morgan Ranch (Fig. 1). It was first recorded by the Texas Historical Commission survey (Lynn, Fox, and O'Malley 1977:Table 22). Local stories concerning the site were recorded by Everett (1981:47-48), and two different tales persist to explain the graves. 
In one, a family of squatters named Murphy died from eating mistletoe berries and were buried together. According to the other version, a group of people travelling through the area contracted diphtheria, died and were buried beside the road. There is no documentary support for either version, and it was hoped that the archaeologists might be able to clear up some of the mystery surrounding this cemetery.

The cemetery consisted of a walled enclosure of tabular sandstone ca. $1.2 \mathrm{~m}$ high within which were five stone crypts. Of these, two smaller ones were located toward the south end, and three larger ones to the north, with a space between the groupings (Fig. 7). No gravestones or inscriptions were visible. There was no opening in the perimeter wall such as that at the cemetery on the Johnston Ranch. The crypts had all collapsed inward (Fig. 8,b), but it was apparent that they had been made in an identical, vaulted design, possibly at the same time. Of the burials, the second from the north wall (Grave 2) appeared to be the most badly disturbed, with stone scattered about and a distinct depression within the crypt.

Archaeologists Hal1 and Etchieson went to the site on July 19, 1982, to photograph and map the cemetery as it was before excavation began (Fig. 8,a). In this way an accurate, unhurried assessment could be made of the site, and a firm basis laid for later measurements and other documentation done in the midst of the pressures of excavation and observation soon to follow.

At 8:20 the next morning the archaeological team was joined on the site by Fox and Wesolowsky, mortician Pat Hurley and his workers, and Harold Pendleton of the USBR arrived soon afterward, and work was begun ( $F i g, 9, a)$. Since there were at least five graves to remove, and it was hoped to accomplish the work in one day, it was necessary to move quickly. Therefore, work was often proceeding in two or more graves at the same time. This required one archaeologist to be limited to overseeing and recording the process, taking detailed field notes, and photographing the burials as they were uncovered by the other archaeologists. The physical anthropologist examined the skeletal remains for evidences of age, sex, and stature, photographed artifacts found with each burial, and saw to it that all bones and artifacts were reunited with the correct individual. Pressure of time was constant, because of the legal and contractual obligation that the remains must be reburied the same day as they were exhumed, and the archaeologists worked without stopping until 3:30 p.m.

The operation was begun by removing a section of the perimeter wal1, starting at the northwest corner. It was noted that the mortar resembled that found in middle-to-1ate 19th-century structures throughout Texas, hard on the surface where exposed to the elements, but soft and friable on the interior of the wall, and containing visible fragments of lime and charcoal.

The graves had been numbered in sequence from north to south on the map drawn the previous day. They were not removed in that order, but will be described here in numerical sequence for ease with reference to the map. In each case the description of the excavation process and observations are taken from the archaeologists' field notes, and the skeletal analys is from the notes of the physical anthropologist. 


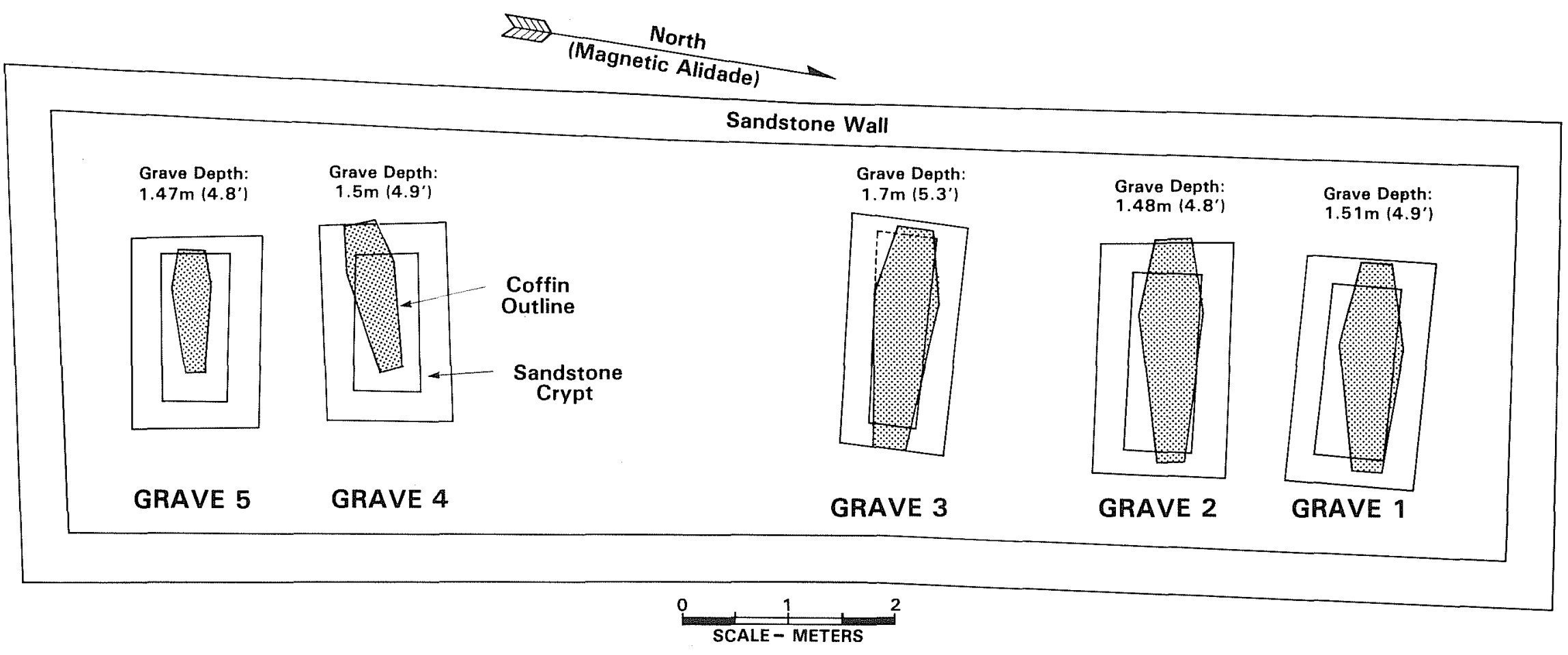

\section{PLAN OF MORGAN CEMETERY - 41 MC 4}

Figure 7. Map of Morgan Cemetery. 


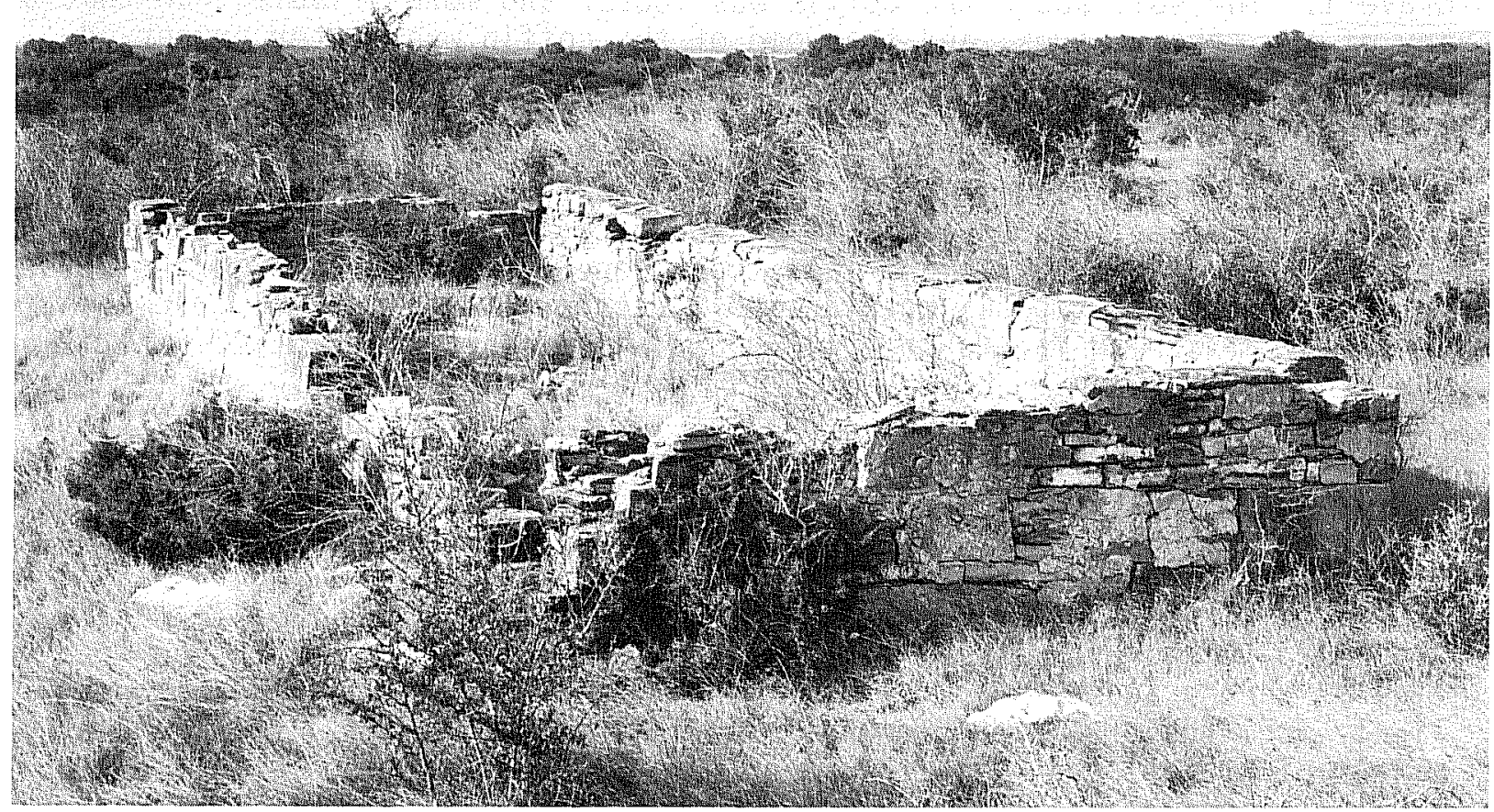

a

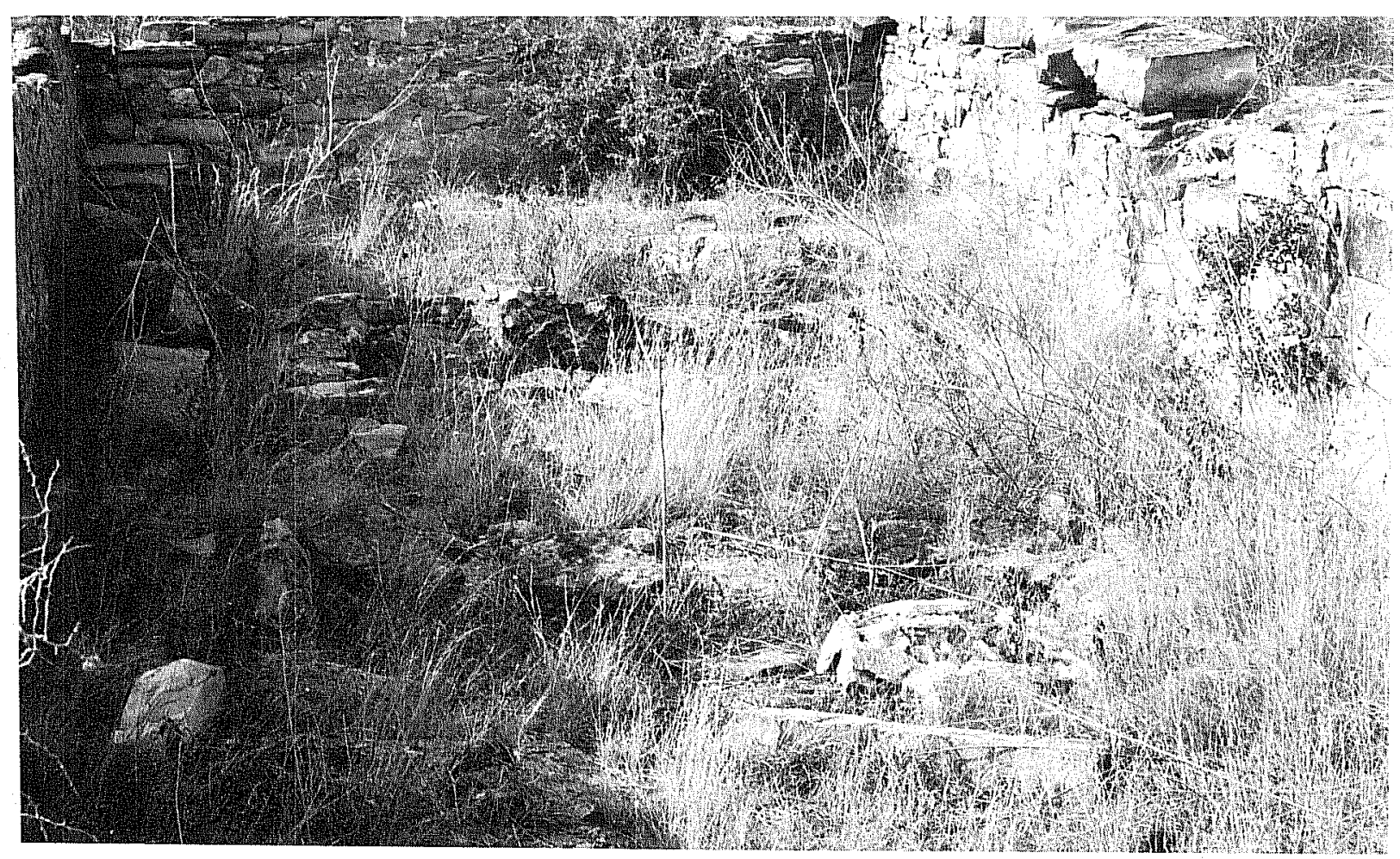

b

Figure 8. Photographs of Morgan Cemetery. a, view of cemetery before work began; $b$, crypts in cemetery. 
Grave 1. The soil above the coffin was looser and more friable than that of any of the other graves, and the wood of the coffin was better preserved, making a distinct outline of the hexagonal-shaped coffin in the soil. The skeleton was apparently complete and well preserved. The bone was sound, although some of the articular ends were not preserved. The skeletal frame was robust, with wel1-developed, masculine features including pronounced mastoid processes, a square mandible, and narrow greater sciatic notches. Age was estimated to be in the late teens since the 3rd molars were erupted but not nearly functional, no synostosis was noted on the skull fragments, the vertebral articular facets were clean and well defined, and dental attrition was minimal.

Fabric in the vicinity of the lower abdomen was preserved by the salts from a number of metal buttons, and a four-hole bone button was also present. These objects were photographed ex situ (Fig. 9,c) and returned to the concrete grave liner with the remains.

Grave 2. This grave was found to be totally disrupted, although the wood outTine of the hexagonal-shaped coffin was intact. Several sizeable stones likely from the crypt were found in the fill of the coffin. The skeleton was partly disarticulated, with the major part of the skull located between the tibiae, which were still articulated with their fibulae. The right humerus was found near the center of the coffin at right angles to the long axis of the grave. The left humerus was in its correct anatomical position. Vertebrae were scattered throughout the top half of the coffin area.

Despite the disturbance, the bones were well preserved and sound. The manubrium was especially large, and clavicles and long bones were robust and large. No parts of the skull or pelvis useful for assessing the sex or estimating age were observed, but judging from the size and robusticity of the long bones, there was no doubt that the skeleton was that of an adult male in the prime of life.

Unfortunately, due to the disturbed condition of the burial and the pressure of time, no artifacts were recovered from the grave except for wood fragments and coffin nails. It is possible to reconstruct some aspects of the graverobbing incident from the evidence recovered during the exhumation. Apparently the event occurred at a point in time when the skeleton could easily be disarticulated. The top of the crypt was removed, and a hole was dug into the center of the grave, perhaps in hope that a gun or some other valuable object had been buried with the deceased. It is interesting that the grave of the adult male was chosen, suggesting that the vandals either knew something of the events surrounding the burials, or that grave markers of some kind were present at the time.

Grave 3. This burial was slightly deeper than the others (see Fig. 7). Small cuprous fragments were found in the vicinity of the skull but it was not possible to reconstruct the artifacts they represented. There was a small, three-hole shell button at the neck and a small, four-hole white glass button at the abdomen, probably from the wrists which lay across this area. 


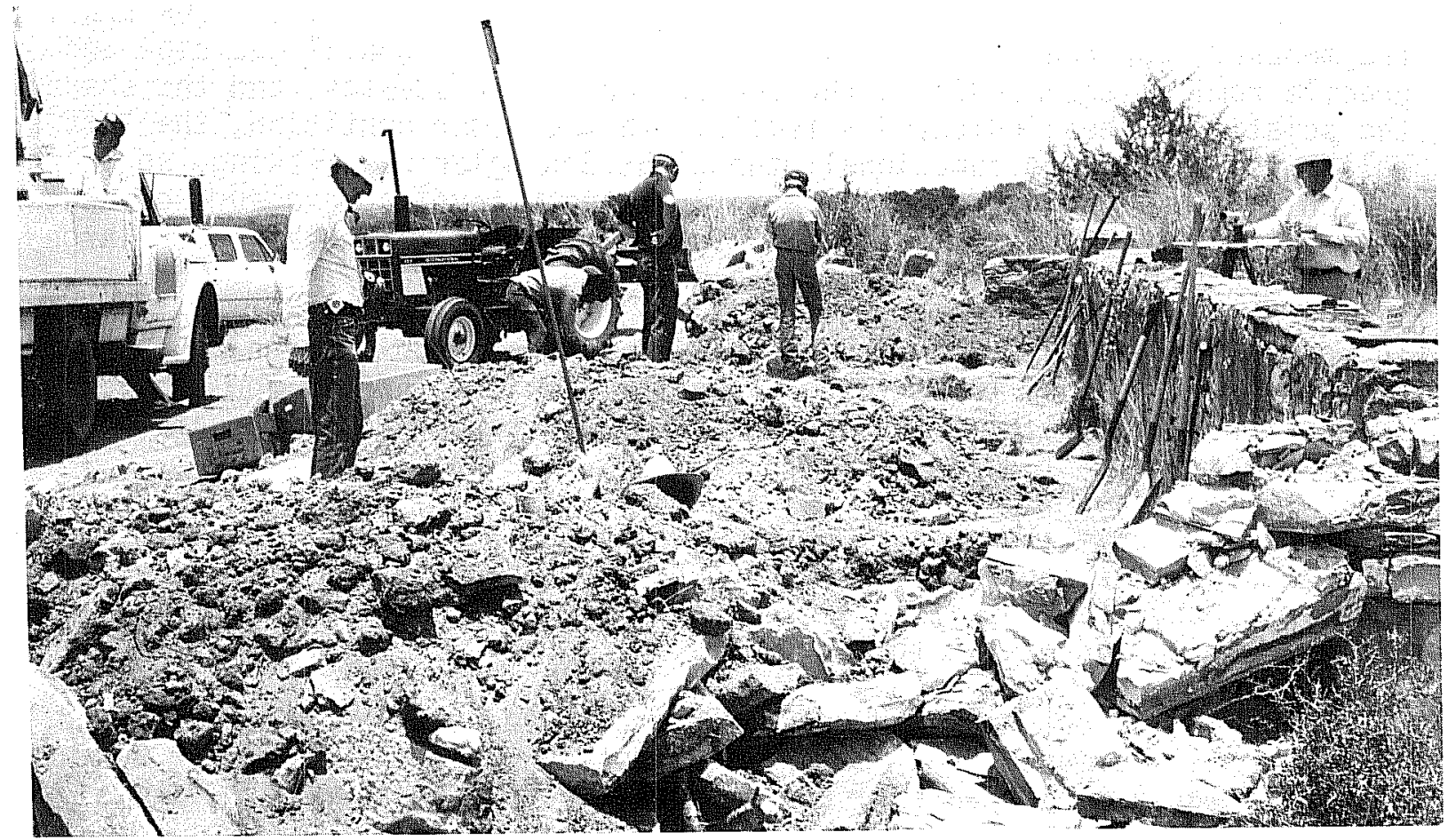

a

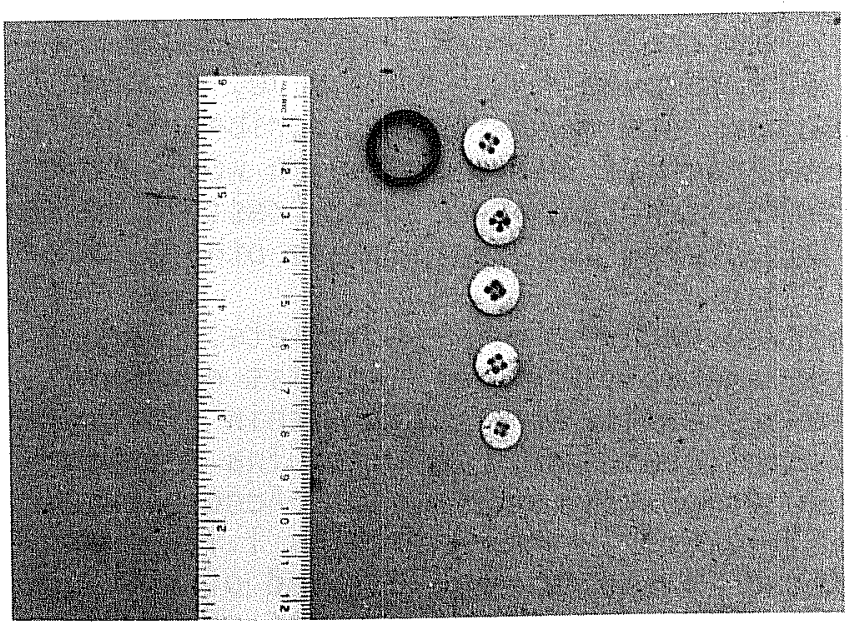

b

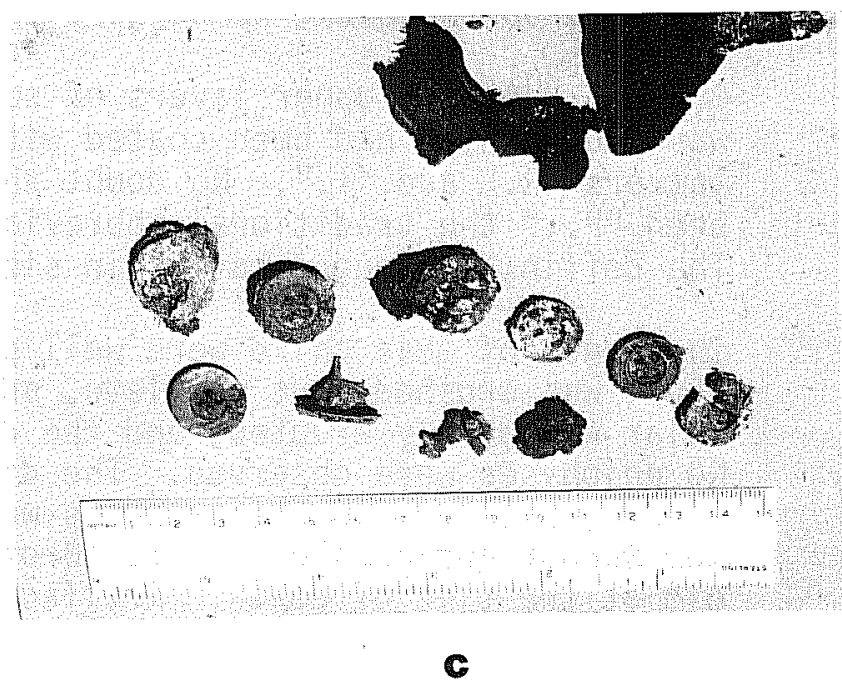

Figure 9. View and Details of Morgan Burials. a, work in progress; b, artifacts from Grave 4; c, artifacts from Grave 1. 
This adult skeleton appeared to be complete and well preserved. The skull was fragmentary, but the mandible was intact. The slight gonial eversion and gracile rami of the mandible, the conical mastoid processes, and the shape of the sciatic notches indicated a female. In the lower dentition, the left 3rd molar was erupted and functional; the right $3 r d$ molar was missing, apparently congenitally. The wear on the lower right teeth involved exposure of dentine over most of the occlusal surfaces. The lower right 1st molar had a large cavity and shared an alveolar abscess with the 2nd molar.

There was a slight amount of endocranial synostosis, but virtually no ectocranial synostosis of the sutures. The age at time of death would have been in the fourth decade of life, approximately corresponding to the age of the male in Grave 2.

Grave 4. The crypts over this grave and Grave 5 were proportionally smaller than those at the south end, preparing us for the discovery of smaller coffins containing children. In this grave the coffin outline was distinctly visible, and was similar in design to the others.

The skeleton was complete and very well preserved, and the bone was sound. The lower 1st permanent left molar was erupted, while the 2nd molar was not. The child was 8 to 10 years of age at death, too young for any reliable evaluation of sex.

In this case, the artifacts conveyed information not obtainable from the skeleton. There was a thin, celluloid ring on the finger of one hand and a four-hole white glass button in the chest area. When the burial was removed, four small, four-hole white glass buttons were found beneath the upper spine. The artifacts were photographed (Fig. 9,b) and replaced with the remains for reburial. Judging by the affinity of small girls for finger rings and dresses buttoned up the back, we suggest this was an 8 to 10 year old girl.

Grave 5. As the upper layers of soil were removed from this grave, a stone was found which had been coated with mortar into which were inscribed the letters "R." and "I.". No doubt the remainder of the inscription would have been "P.," the traditional abbreviation for requiescat in pace (rest in peace). The coffin, although smaller in size, was shaped the same as the others.

The bones of this child were well preserved and reasonably complete. The skull was crushed, but complete, and the mandible intact. The 1st deciduous molar was partly erupted, and the deciduous canine was still within its crypt. No epiphyses were observed. The diaphysis (shaft) of the left ulna measured $0.08 \mathrm{~m}$ in length; no other bones were so completely preserved. According to the Schour and Massler charts (Brothwe11 1965:59), the child was 1 1/2 years old at the time of death. Artifacts found in the grave consisted of the unremarkable coffin nails, a small tack, and a few tiny fragments of an unidentifiable green metal similar to that found in Grave 3.

When the last burial had been exhumed, the mortician excavated the entire area between Graves 3 and 4 but no additional graves were found. 


\section{Discussion}

Looking at the local accounts which attempt to explain this cemetery, Everett (1981:47) remarks that no family by the name of Murphy is mentioned in the census records. There is a 10-year gap between census-taking, however, and much can happen in an area in a decade. The position of one of the old trails through this area (Corps of Engineers, U.S. Army 1920) would put this site close to the road. This would tend to favor the second story about diphtheria among a group of travellers. Unfortunately, no clues could be recovered from examining the remains as to the cause of death. The identical design of the crypts would suggest that they were built with some care and probably all at the same time. But it does not seem likely that a community would go to the trouble to erect such structures over the burial of passing strangers beside the trail.

Once analyzed, this group of burials is consistent with what we might expect from a family composed of man and wife, a teen-aged son, a girl of 8 to 10 years, and a smal1 1 1/2 year old child. There are significant time gaps in this family group based on the size of a typical Yarbrough Bend family. According to the 1870 Census (USDI 1870) and local family histories (MCHBC n.d.) families generally contained five to eight children by the time the parents reached their mid-40s. We suggest, therefore, that there may have been some additional children who survived the catastrophe, whatever it may have been. Perhaps the empty spot in the cemetery was reserved for other family members who remained in the area. Since it was not at all unusual for orphaned children to be taken and raised by others, we will probably never be able to trace the identity of this unfortunate group.

\section{Yarbrough Bend Cemetery (41 MC 18)}

The Yarbrough Bend Cemetery was located on the Edna Henry Ranch, on a comparatively, level terrace overgrown by mesquite, yucca, cactus, and low brushy species, south of the Frio River in the approximate center of the Yarbrough Bend settlement (Fig. 1). It was accidentally disturbed during brush clearing by Joseph Coughran of Tijden in the mid-1950s (Everett 1981:44). Since there was little local knowledge of the cemetery at the time, Coughran was surprised to discover that he had dislodged two gravestones in the dense brush, those of John and Frances Yarbrough. He picked up the scattered fragments of Mrs. Yarbrough's stone and, restoring the original shape as best he could, laid them on the surface near where her husband's stone had fallen (J. A. Coughran, Jr., personal communication).

The property owner since that time denied access to the area. But a determined approach by a Yarbrough descendant, Gladys Ritter, was successful in gaining entrance to the site in 1964. She observed the Yarbrough stones and, in addition, recorded one stone marked "Infant Daughter of Joseph Walker and Amanda Yarbrough" and another, "Sorrow Zevish (probably Zavish) Died July 2, 1874." She noted eight additional grave markers whose inscriptions were illegible (Everett 1981:44), for a total of 11 stones.

In 1966, the McMullen County Historical Survey Committee examined the cemetery, found the Yarbrough and Walker markers, and noted that eight additional "rocks" 
bore initials (Zavisch 1982). Various family members have suggested that the following may also be buried in this cemetery: William C. Walker, Sarah Walker, Frank Drake (brother of Mrs. Walker), infant child of Benjamin F. Winters, Amanda Harrison, and a member of the Williams family (MCHBC n.d.: 444; Everett 1981:44).

The landowner resumed denying permission to enter this section of Yarbrough Bend unti1 1981, when a survey team from the Center for Archaeological Research under the direction of Erwin Roemer (1981:86) made the first archaeological survey of the property. Roemer's observations were similar to those of the McMullen County Historical Survey Committee, except that they found no trace of engraved stones other than those of the two Yarbroughs. A drawing of the Yarbrough stones from Roemer's report is included here (Fig. 10), as a matter of record.

The circumstances of the founding and settlement of the Yarbrough Bend community have been related above. A brief history of the Yarbrough family is now in order, since this is primarily their family cemetery.

John Swanson Yarbrough and his two eldest sons arrived in Texas in 1832 and all served in the Army of the Republic of Texas. One of his sons, John Swanson Yarbrough, Jr., was killed in the Battle of San Jacinto in 1836 (MCHBC n.d.:439). In 1845 or 1846, Yarbrough married Mrs. Frances Coker Moore Tope, a widow 36 years his junior. It was the third marriage for each, combining two families of small children. They had a daughter, Amanda, born in 1846 in crockett, Houston County (ibid.). The family moved to Yarbrough Bend in 1858. Amanda later married Joseph Walker, one of the Yarbrough's neighbors (MCHBC n.d.:446).

John Yarbrough was shot to death in an argument with a horse trader in 1862 at the age of 88. His wife, Frances, continued to operate the farm and served the community as midwife and nurse until her death in 1868 (ibid.:444).

Before the work of exhumation began, the Yarbrough Bend Cemetery was an area thickly overgrown with brush and trees, on a level terrace about $300 \mathrm{~m}$ south of the river. A tangle of barbed wire and rotted fence posts at one side suggested that at some time the cemetery had been surrounded by a wire fence. According to local history (MCHBC n.d.:444), it once was enclosed by a low stone wall. No trace of such a wall is visible today.

On September 20, 1982, archaeologists Ha11, Fox, Wesolowsky, Ireland, and Etchieson, joined by Bobbie Ferguson from the Amarillo, Texas, office of the USBR, went to the site of the cemetery and began clearing brush from the area. Yarbrough descendants Gladys Ritter and Carmen Pierce were also present. A search was made for indications of graves in the vicinity of the two broken Yarbrough stones and a number of white cut-stone foot markers set into the ground. The latter measured 5 to $10 \mathrm{~cm}$ in section, and had been broken off ca. 10 to $15 \mathrm{~cm}$ inches above the ground surface. Fragments lying about the area could be joined to the broken stubs, which indicated that their original projection above the ground was approximately 25 to $30 \mathrm{~cm}$. The stone from which the footstones were made appears to be the same as that of the plinths and the markers--a fine-grained, light tan stone, easily scratched with a knife. It appears to be the same material from which the Taylor and Morris gravestones were made. 


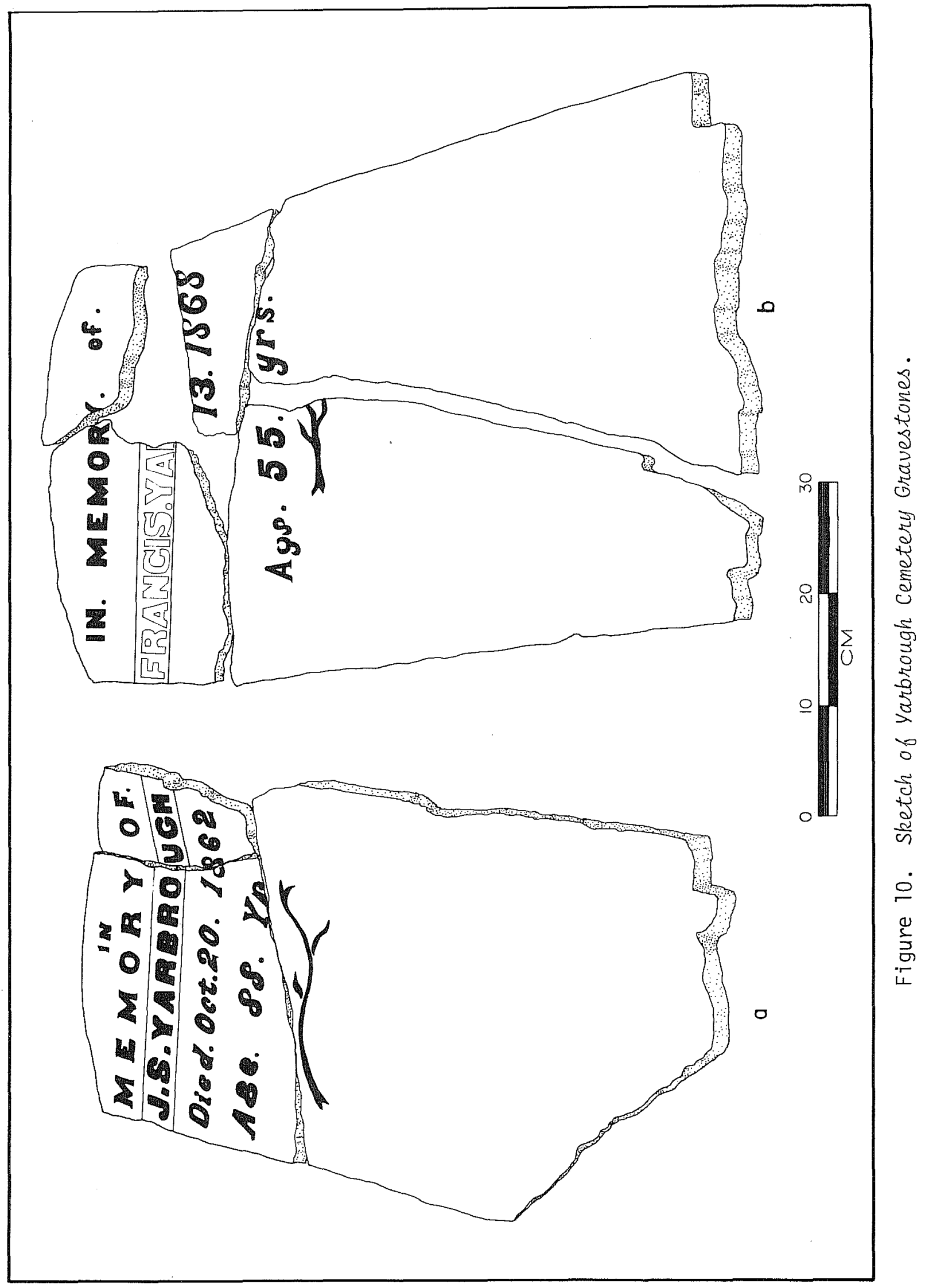


The mortician, Pat Hurley, arrived, viewed the thick underbrush, and returned to Pleasanton to obtain heavier equipment. Meanwhile, the archaeologists scraped out a shallow trench approximately two meters to the west of the line of footstones, to locate the bases of headstones that were broken off by the chaining operation in the mid 1950s. Two stone plinths, nearly identical in design to those found at the Taylor-Morris grave, were found in this trench. They were of a whiter, more durable stone than that of the gravestones of the Yarbroughs. There was also an unshaped slab of sandstone set on edge, which protruded slightly above the surface (see Fig. 11, Grave 6). Careful examination of the slots in the plinths and the broken tongues on the Yarbrough gravestones confirmed that the grave farthest south should be that of Frances Yarbrough and the remaining plinth should mark John Yarbrough's grave. Evidently his stone had been merely knocked over during the chaining, and it lay across his grave (Fig. 12,a). The inscription on each stone would have faced the foot of the grave. The trenching and general surface examination also revealed a small, jumbled rectangular pile of roughly shaped sandstone between the graves of the Yarbroughs. This was marked at the east end by a squared sandstone slab set upright in the east wall of the pile (Fig. 12,b). The mortar among the stones was typical 19th-century lime and sand mortar of a light gray color, containing bits of charcoal, ash, and chunks of lime. It appeared that this might be the grave of the Walker infant mentioned by the McMullen County Historical Survey Committee as it was considerably smaller than the Yarbrough graves.

The remainder of the day was spent recording and photographing the cemetery as it had so far been revealed. No evidence (cairns or the like) of additional graves were found in the area. A site map was begun, using an alidade and plane table.

The following day a Caterpillar bulldozer was used to clear a large area completely surrounding the known graves (Fig. 13), removing 30 to $37 \mathrm{~cm}$ of topsoil in order to find any additional grave pits. This earthmoving activity was carefully monitored by the archaeologists who worked closely with the morticians and equipment operator. The natural soil was a dark, chocolate brown loam, and it had been observed in the trenching the day before that the outlines of mottled tan and brown grave pits showed up plainly. Two additional pits were found at the north end of the original row. Although more than $700 \mathrm{~m}^{2}$ were cleared and scraped, no further pit outlines were found. A full day was required to do this clearing, scraping, and surface examination.

A number of additional family and community members were present on the site during this and the following days' work. We appreciated the opportunity to learn more about the Yarbrough family and to explain and demonstrate our involvement in the project.

On September 22, the archaeologists and the mortician and his workers arrived at the site, and excavations were begun. The graves were numbered in the order in which they were removed, since the total number and exact location of the graves were not known. A Bobcat was used to excavate each grave pit until evidence of the coffin in the form of wood fragments and/or nails was encountered. The archaeologists then uncovered and recorded the burials. The process of excavation, recording, and removal of the six graves took two days. 

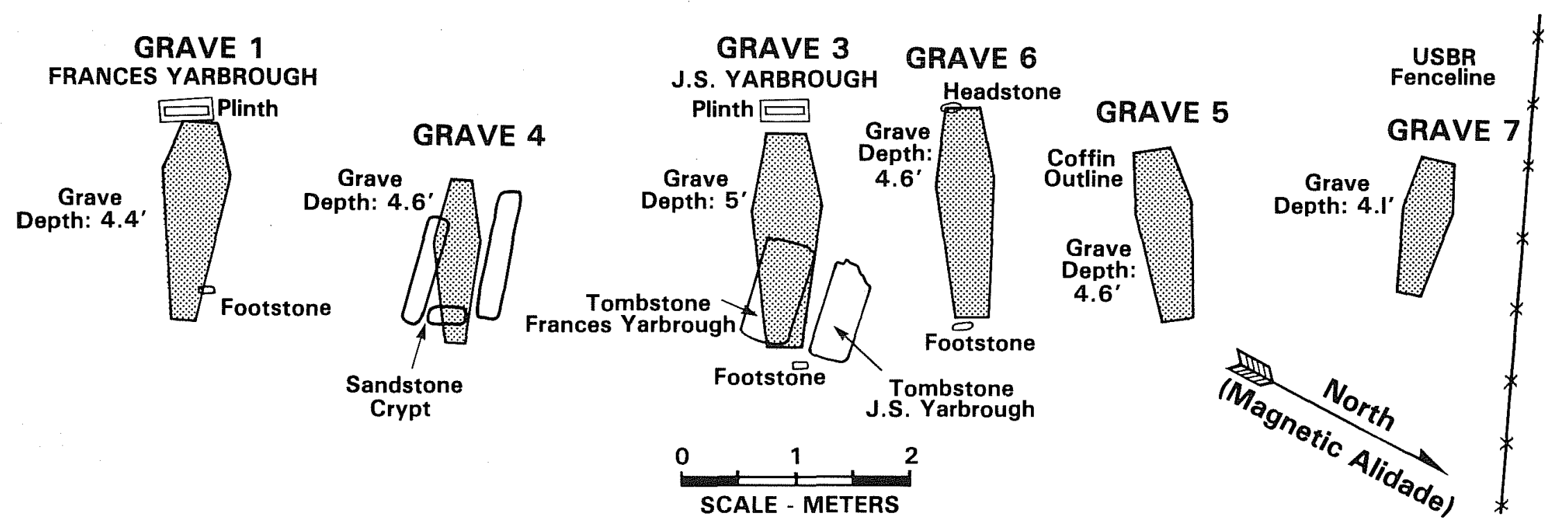

\section{PLAN OF YARBROUGH CEMETERY}

Figure 11. Map of Yarbrough Cemetery. 


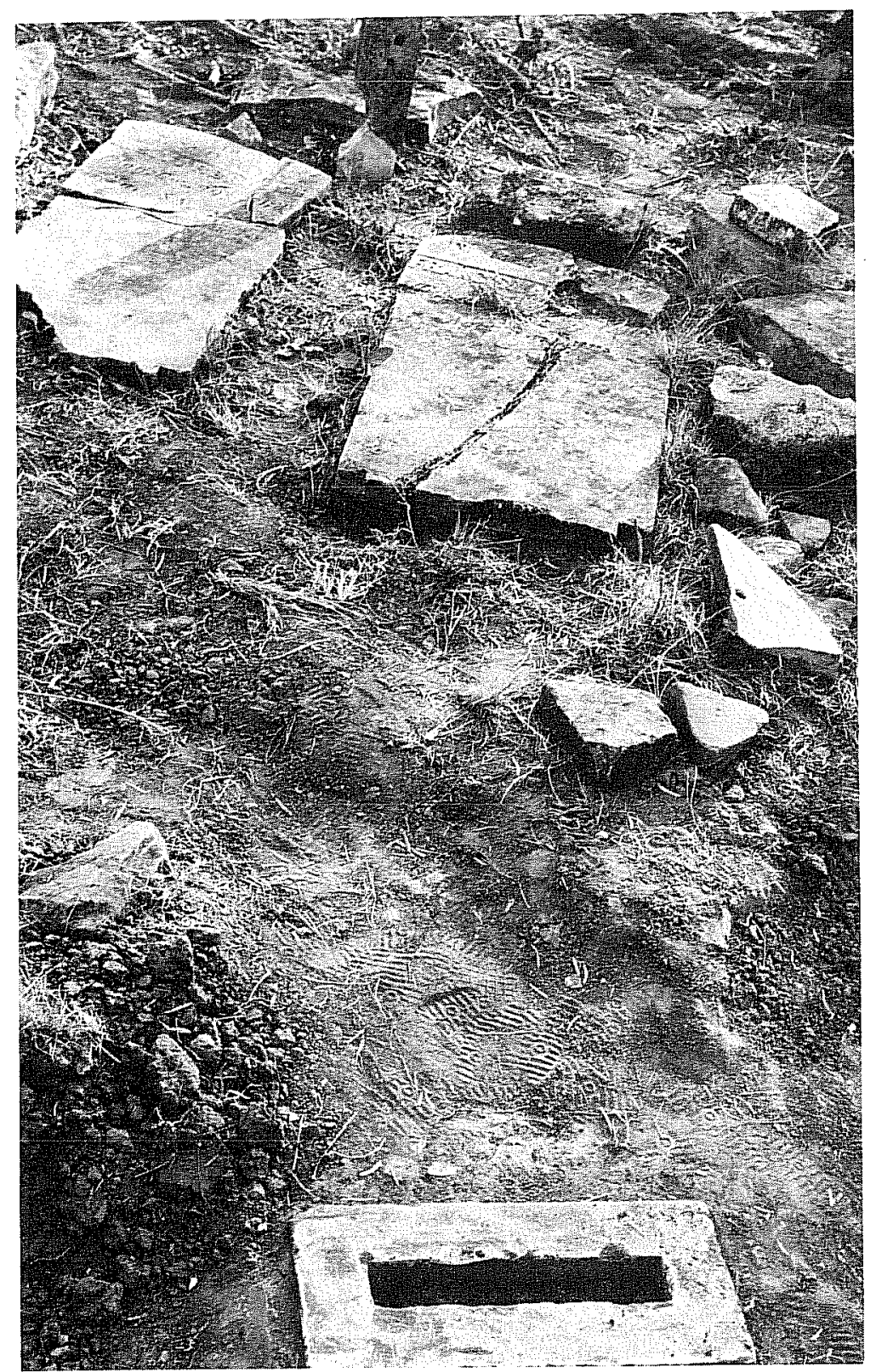

a

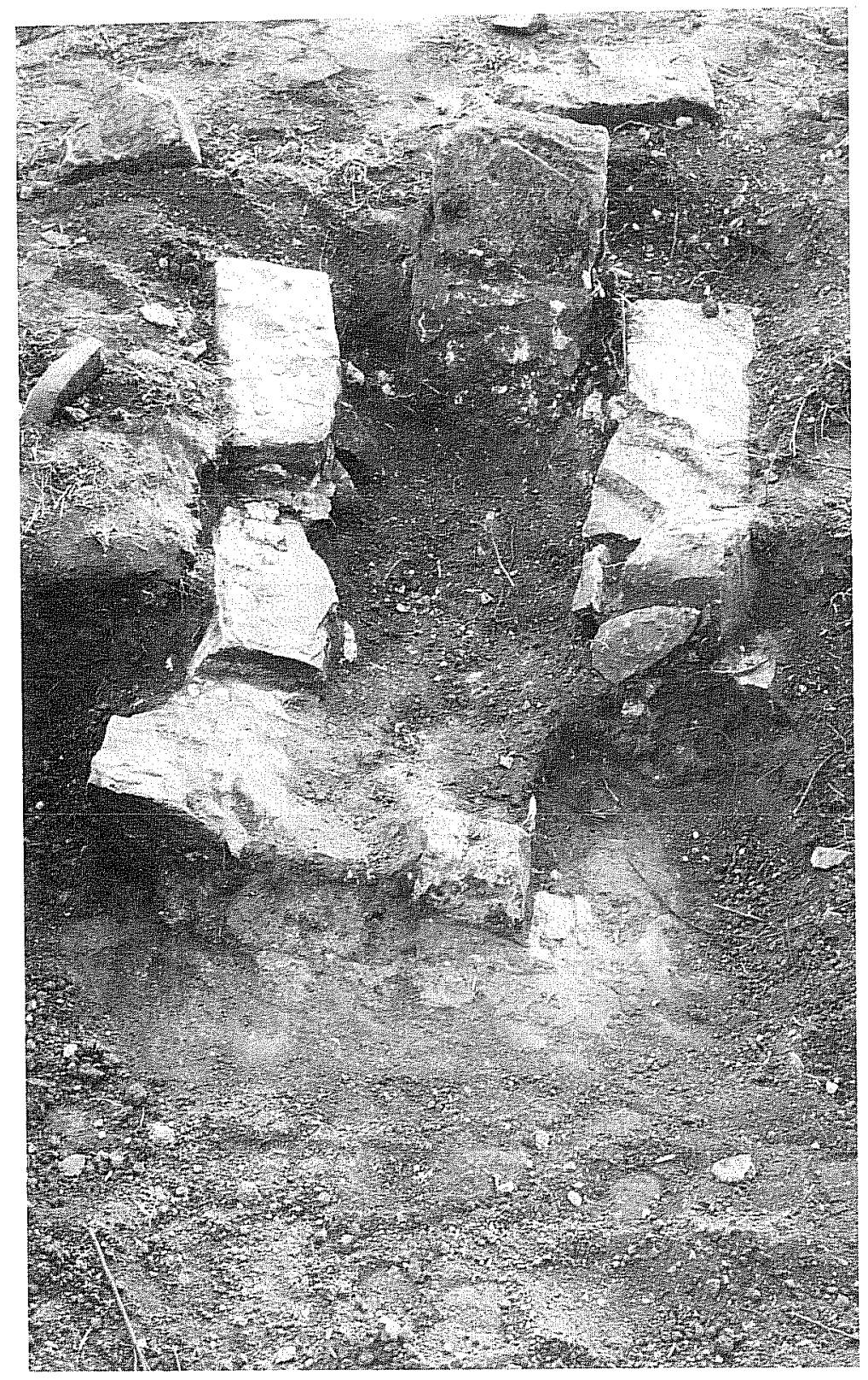

b

Figure 12. Photographs of Graves. a, John Yarbrough grave before excavation; b, crypt between Yarbrough graves. 


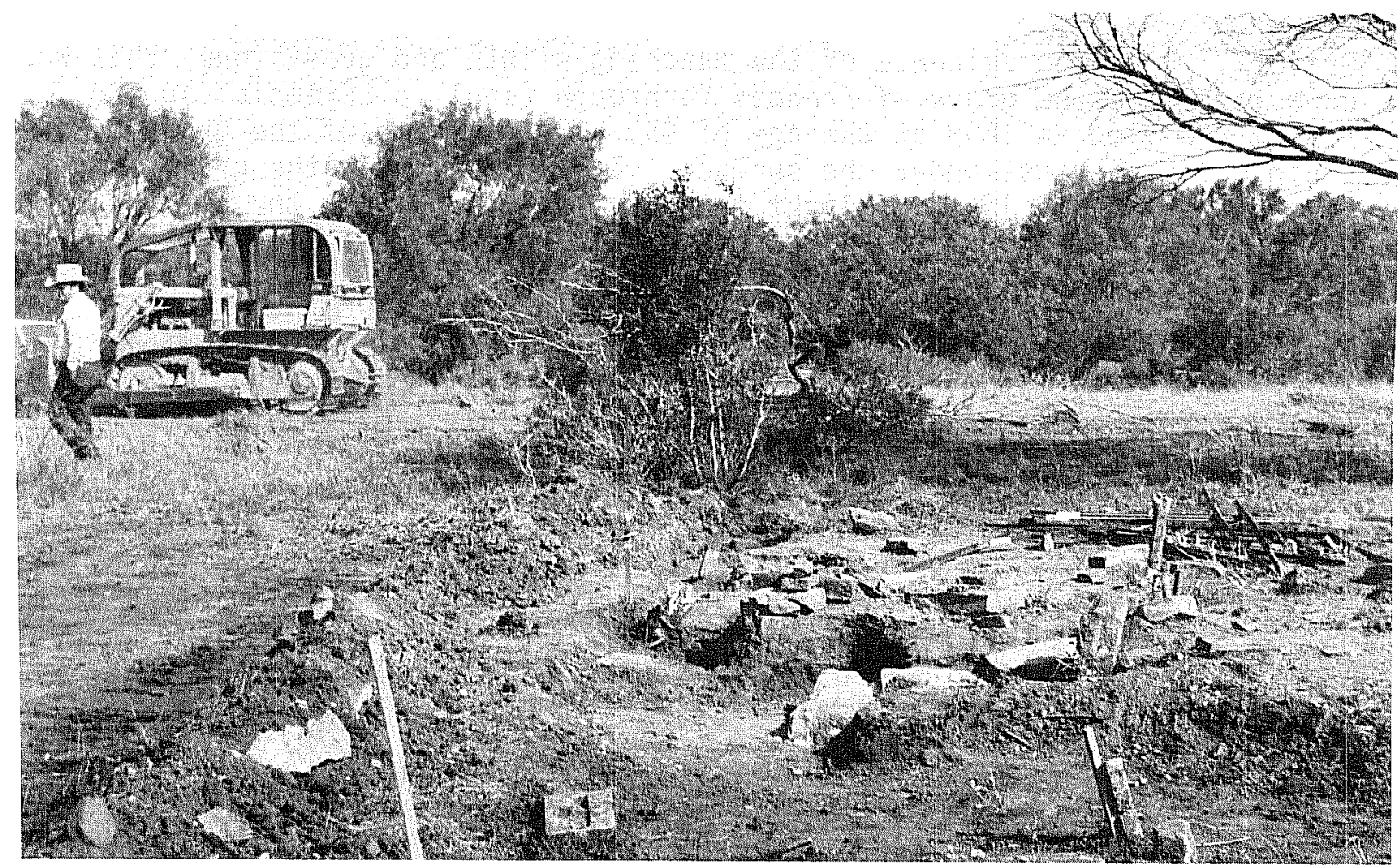

a

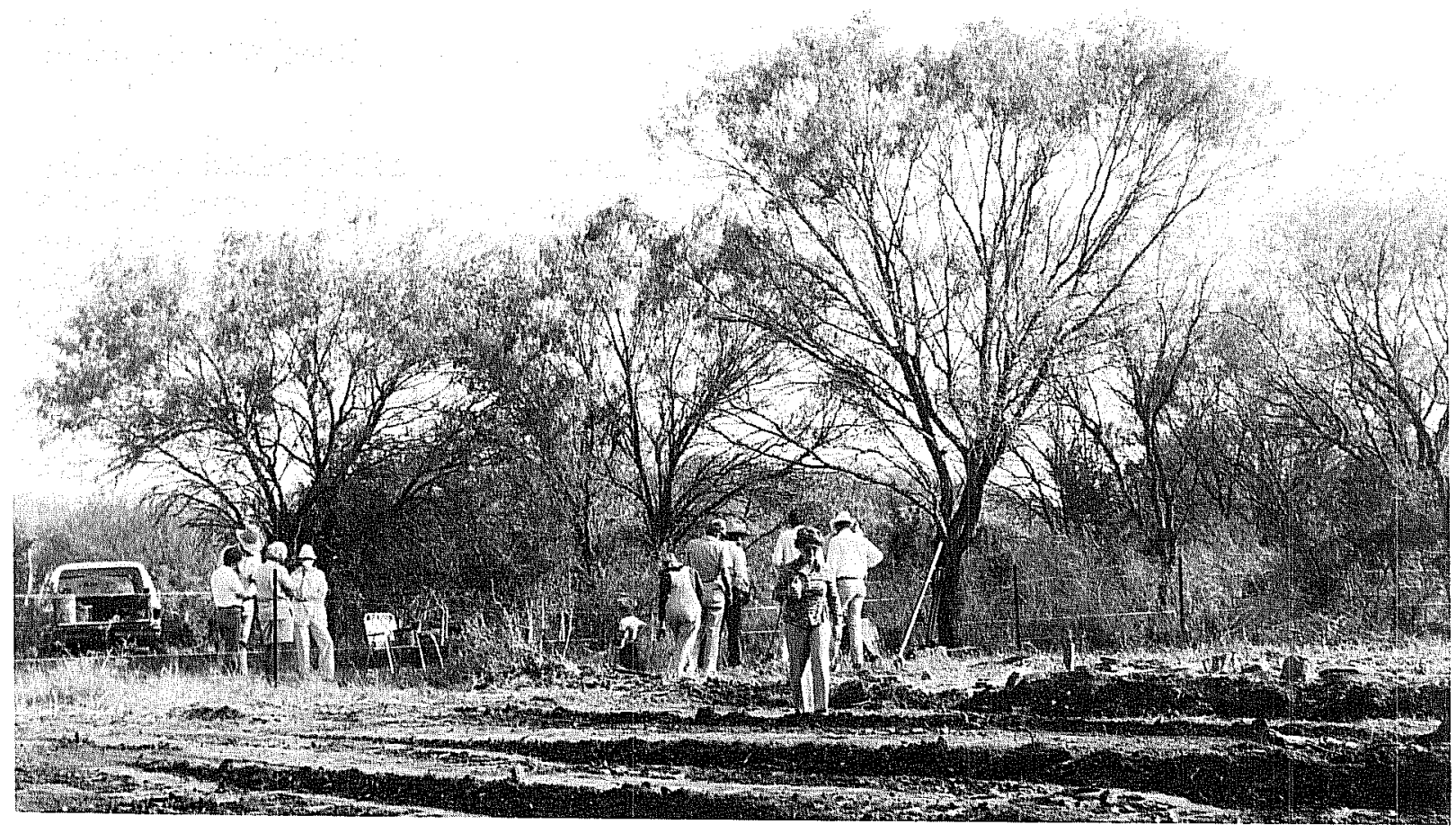

b

Figure 13. Clearing Cemetery Before Excavation. a, area where graves were located, looking north; b, scraped area surrounding graves, looking northeast. 
Grave 1. From the evidence of the matching plinth and gravestone, this was expected to be the grave of Frances Yarbrough (spelled "Francis" on the stone) who died in 1868 at the age of 55. The outlines of the grave pit were plainly visible just under the surface. It appeared that the grave may have been capped with a layer of light tan clay. At ca. $1.05 \mathrm{~m}$ the first coffin nails and wood fragments were found, and an archaeologist took over the excavation. The coffin was hexagonal.

The human remains were intact and in good condition, except for fragmentation of the face and cranial vault. The hands were crossed over the abdomen. Judging from the supraorbital tori, small mastoids, wide greater sciatic notches, and proportions of the sacrum, the sex was assessed to be female. Age was estimated to be in excess of 40 years, based on complete fusion of the epiphyses, including the medial clavicles, and well-advanced endocranial and ectocranial synostosis. The upper right canine, worn into the pulp, was the only tooth that remained at death. There was virtually no sign of arthriticlike lipping in the spine on any of the joints. These observations would seem to confirm the identification of the burial as that of Mrs. Yarbrough, still a vigorous and active woman at the time of her death at the age of 55 .

The only pathology noted was a gross cancellous thickening of the diploë of the cranial vault and to a lesser extent the innominate. A lambdoidal fragment was $1.4 \mathrm{~cm}$ thick (the total thickness of the vault). The inner and outer tables (see Appendix III: Glossary) were apparently normal, leaving some $12 \mathrm{~mm}$ for the diploë. A sagittal section was ca. $1.0 \mathrm{~cm}$ thick, again with the bulk of the enlargement confined to the diplö̈. The innominate displayed an abnormal amount of cancellous bone, but the amount was difficult to quantify because of the normal contours of the innominate. The symptoms are typical of skeletal responses to various forms of chronic anemia. None of the other bones appeared pathological.

Grave 2. From the dimensions of the pit outline, we anticipated that Grave 2 was that of a subadult. Indications of the hexagonal coffin were found at approximately one meter. The skeleton was complete and in good condition, although the skull was fragmented. The hands were crossed over the abdomen. Tiny green fragments of a straight pin approximately three centimeters long were found beneath the sku11. A deer scapula lay over the chest area, but was separated from the burial by three or four centimeters of earth. It was not possible to determine whether this bone was intentionally included in the grave. The deciduous dentition was erupted and functional, and the 1st permanent molar was still below the gum line although about to erupt. The age at the time of death was assessed at five years, and the sex could not be evaluated. No evidence of the cause of death was observed on the skeleton.

Grave 3. The location of the plinth and the fallen stone identified Grave 3 as that of John S. Yarbrough, who died in 1862 at the age of 88 . First indications of the coffin, again hexagonal, were found at ca. $1.2 \mathrm{~m}$ below the surface. The skeleton was in good condition and complete with the hands crossed over the abdomen. A sherd of blue-banded earthenware was found in the grave fill but no other artifacts were observed. All epiphyses were fused but the skull was too fragmented to permit an observation of synostosis. The 
skeleton was evaluated as that of a male over 55 years of age. No lower teeth were present at death. The same thickening of the cranial vault was present as in Burial 1.

Grave 4. The stones of the crypt of Grave 4 were removed, revealing the pit outline. At ca. $1.2 \mathrm{~m}$ below the surface, nails and wood fragments of a hexagonal coffin were found. Rather than an infant as expected from the size of the crypt, the skeleton was evaluated to be that of an 11 year old child. None of the epiphyses of the long bones were fused, but they were present, and ossification of the epiphyses was advanced. The deciduous dentition was erupted and functional. The 1st permanent molar was erupted and functional, and the crown of the 2 nd permanent molar was calcified but had not erupted above the gum line.

The bones were in good condition and complete, the arms crossed at the waist. A blue-banded earthenware sherd was found in the grave fill. No other artifacts were included in the burial. No evidence of pathology or cause of death was found.

Grave 5. The pit outline of Grave 5 was smaller than those of the adults, suggesting that it was another child. At ca. $1.05 \mathrm{~m}$ the first signs of the hexagonal coffin were found. The long bones were intact and in good condition. Although fragmented, the skull appeared to be complete. The left arm lay across the lower abdomen, the other extended along the side. No artifacts were found in the grave.

The skeleton was assessed to be that of an eight year old child. The deciduous dentition was erupted and functional, the lst permanent molar was erupted and functional, and the 2nd permanent molar was still within its crypt. Also, none of the epiphyses were fused although a 11 centers of ossification in the major long bones seemed to be present. The individual was too immature for an evaluation of sex.

Grave 6. Grave 6 was marked at either end by a small slab of sandstone set on edge into the ground. No other identification was present. The first nails of the hexagonal coffin were reached at ca. $1.05 \mathrm{~m}$. The remains, those of an adult, were in sound condition and complete. The hands were laid across the stomach. There were no artifacts included in the grave.

There was some thickening of the cranial vault, and the teeth were already well on the way to the condition seen in Burials 1 and 3 because of severe attrition and decay.

Judging from the brow ridges, configuration of the mastoids, gracile nature of the long bones, shape of the mandible, and shape of the greater sciatic notches, the individual was a female. All epiphyses, including those of the medial ends of the clavicles, were completely fused. Three 3rd molars were erupted and functional. A complete lack of joint involvement and slight dental attrition suggest an age of late $30 \mathrm{~s}$ to mid $40 \mathrm{~s}$. Pathological thickening of the diploë of the cranial vault $(1.0 \mathrm{~cm})$ and some thickening of the innominata were noted.

Despite continual examination of the area throughout the time that work was in progress, no further graves were discovered. The discrepancy between the 
number of graves anticipated and the number which were actually present was difficult to explain. We were beginning to wonder if the missing burials might be in another cemetery in the Yarbrough Bend area, and our informants mistaking one cemetery for another.

\section{Discussion}

We found six graves in the Yarbrough Bend Cemetery. Of these, two were identified as those of Mr. and Mrs. John S. Yarbrough. The child buried between them could well be one of the Joseph Walker children, but was found not to be a still-born infant as reputed (MCHBC n.d.:447). We have been unable to identify the five (Grave 2) and eight (Grave 5) year old children.

It seems possible that the woman (Grave 6) might have been Amanda Harrison, since she is supposed to be buried in this cemetery. It does seem peculiar, however, when her small son is known to have been buried in the Byrne Cemetery. The skeleton was of the proper age, since Mrs. Harrison has been reported to have died in the 1880s which would have made her in her 40 s at the time of death (United States Department of the Interior, Office of the Census 1870).

Where are the others who were supposedly buried in this cemetery? The only answer seems to be that confusion has set in over the years between the various small family cemeteries in the valley. Where markers either never existed, have been removed, or have disintegrated if they were made of wood, all we have is family tradition to guide us.

Special care was taken to search for the stones marked with illegible inscriptions reported to be there. While a number of shaft-shaped foot markers of whitish tan, soft stone and a head and foot marker of fieldstone were found, they bore no markings.

A]though the individuals were buried over a span of 10 years or more, there were a number of similarities in the burial practices used. The coffins were of identical design, each apparently tailored to the size of the deceased. No indications of clothing or personal belongings were found in any of the burials, with the possible exception of the deer scapula above Burial 2. Given the frontier existence of these people and the probable lack of store-bought amenities, it seems possible that this deer bone might have been, or formed part of, a favored toy of a five year old child, and could conceivably been laid on top of the coffin at burial. No other animal bones or bone fragments were observed during excavation of the cemetery. The absence of indications of clothing, and the presence of a straight pin in Grave 2 suggest that these people may have been buried in shrouds.

No explanation has so far been found for the presence of sherds of 19th-century ceramics in Graves 3 and 4. Roemer (1981:86), during his survey, noted the presence of "a few earthenware sherds" in the general area. No structural remains have been found in the immediate vicinity, and there has been no evidence in any of the cemeteries in this general area for the custom occasionally observed elsewhere in the United States of placing broken ceramic vessels on the grave (Jordan 1982:17, 21). 
The arrangement of the graves suggests that this is strictly a family cemetery. Indeed, it may well be that the original name given it was the Yarbrough Cemetery and that the name Yarbrough Bend Cemetery developed more recently, after the death of the last people who would be aware of the original name. The presence of a child's burial between the Yarbroughs would seem to indicate that a formal arrangement of the husband and wife side by side was not considered of primary importance.

The slight differences in their design suggest that the markers for John and Frances Yarbrough were commissioned and installed at different times, probably in each case not long after they were buried. The material and general design are similar to those of the Morris and Taylor stones from 47 MC 6, a circumstance that indicates a common source and artisan, perhaps within the community or nearby. A local type of stone which is similar in appearance is now pulverized to be used for road surfacing (Eddie Reeves, personal communication).

\section{Byrne Cemetery}

The Bryne Cemetery was located on the old Byrne Ranch, west of the Frio River and approximately $6 \mathrm{~km}$ west of the old townsite of Calliham. The site is on the sloping edge of a high terrace overlooking the river valley, and commands a fine view to the northwest, north, and northeast. Several large clumps of century plants with towering flower stalks mark the site from afar, and the entire general area is overgrown with low, brushy plants and cactus.

Two cast-iron grave fences, a wire enclosure, and two fieldstone crypts identified the site as a 19th-century cemetery. No evidence was found for an enclosing wall or fence.

When the cemetery was first recorded by survey archaeologists, in 1977, eight graves were visible. Five of these were marked, and three were not (Lynn, Fox, and 0'Malley 1977:46). The marked graves included those of Dr. and Mrs. George Dilworth, 1894 and 1868; Miss Eliza Byrne, 1911; a Henry family infant, 1913; and Jasper Harrison, aged 3, 1869. Unfortunately, no historic photographs of these markers have been found, and only the marker for Eliza Byrne and a wooden cross on the Henry infant's grave were still visible when we arrived in 1982 to move the cemetery. Other burials believed to be located in this cemetery were those of Charles T. Taylor, Joseph T. Calliham, and a member of the $0^{\prime}$ Connor family (J. R. Henry, personal communication).

The cemetery was located on land which was first occupied by Dr. George Anson Dilworth and his family about 1858 (Curtis Dusek, personal communication). The Dilworths were among the first settlers of Yarbrough Bend, and were close friends of the Yarbrough family. Of the two children the Dilworths brought with them to Yarbrough Bend, one, Mary Calpernia, died at the age of seven (MCHBC n.d.:110) and was probably the first individual buried on the hillside. Mrs. Dilworth bore four additional children during the nine years after they arrived at Yarbrough Bend. In 1867, she died and was buried near her daughter (Clara Dilworth Wyatt, personal communication). Dr. Dilworth was the only doctor for many miles around, and was known to travel great distances in any weather when his services were needed (Dobie 1981:238). Therefore, he was 
away from home much of the time, and, after the death of his wife, he left the younger children in the care of the eldest son, George Blackstone Dilworth or with neighbors. The Dilworth family moved to Tilden in 1880 . Dr. Dilworth continued his career as a country doctor until he fell into an open well and broke his back in 1892. His daughter, Margaret Yarbrough Dilworth Sling, nursed him until his death in 1894 (MCHBC n.d.:110). He was buried next to his wife in this cemetery on the hillside.

In 1879, Charles Robertson Byrne of Aransas County had bought the 1 and on which the cemetery was located, as part of what was to become the Byrne Ranch. He moved his family into a new house half a mile across the valley from the cemetery in 1881 or 1882 (MCHBC n.d.:266).

When she retired as head of Lanier Academy in Aransas County (Wood 1971:116), Miss Eliza Byrne went to live with her brother, Charles, and his family on the ranch. She died in 1911 and was buried across the valley in the old cemetery. In 1913, in what was probably the latest grave in the cemetery, a sti11-born infant of the Henry family was buried next to Aunt Eliza (J. R. Henry, personal communication).

On November 1, 1982, David Stewart of the Eckols Funeral Home met the archaeological crew on the site. A number of Byrne and Dilworth descendants were also present, and they generously shared with the archaeological crew their knowledge of the family members buried there, and watched with interest as the disinterment was carried out. Mr. J. R. Henry was particularly helpful in pointing out locations of graves he had observed in earlier years.

A backhoe was used to remove the overburden above the remains of the coffin in each grave, the loose soil was shoveled out down to the level of the coffin 1id. The archaeologists then exposed and recorded the burial. The physical anthropologist examined and wrote observations on each individual before the remains were removed to marked containers for transport and reburial in the Hill Top Cemetery in Tilden. After the eight graves with surface features were excavated, a Champion maintainer was used to clear the surface of the entire area and to remove the topsoil in order to search for the outlines of additional grave pits. These showed up readily as mottled, yellow tan rectangles in the darker brown of the surrounding soil. They were arranged in two main rows, with a third, partial row to the west and a single burial to the east (Fig. 14). The grave pit outlines ranged in size from adult (ca. $76 \mathrm{~cm}$ by $2 \mathrm{~m}$ ) through smaller, juvenile size (ca. $62 \mathrm{~cm}$ by $1.5 \mathrm{~m}$ ) down to several which were those of infants (ca. $62 \mathrm{~cm}$ by $90 \mathrm{~cm}$ or $1.2 \mathrm{~m}$ ). Also found by this grading operation were rows of rotted wooden posts of grave enclosures in an area at the west edge of the cemetery. This grading operation was efficient and successful in that 12 additional graves were located for which there had been no surface evidence.

The total time required for location, excavation, recording, and removal of the 20 graves in the Byrne Cemetery was five days. It could not have been accomplished in this amount of time without full cooperation between the funeral director and the archaeological crew, plus the extra help of visiting archaeologists, Patience Patterson and Mary Jane McReynolds on November 9 and 


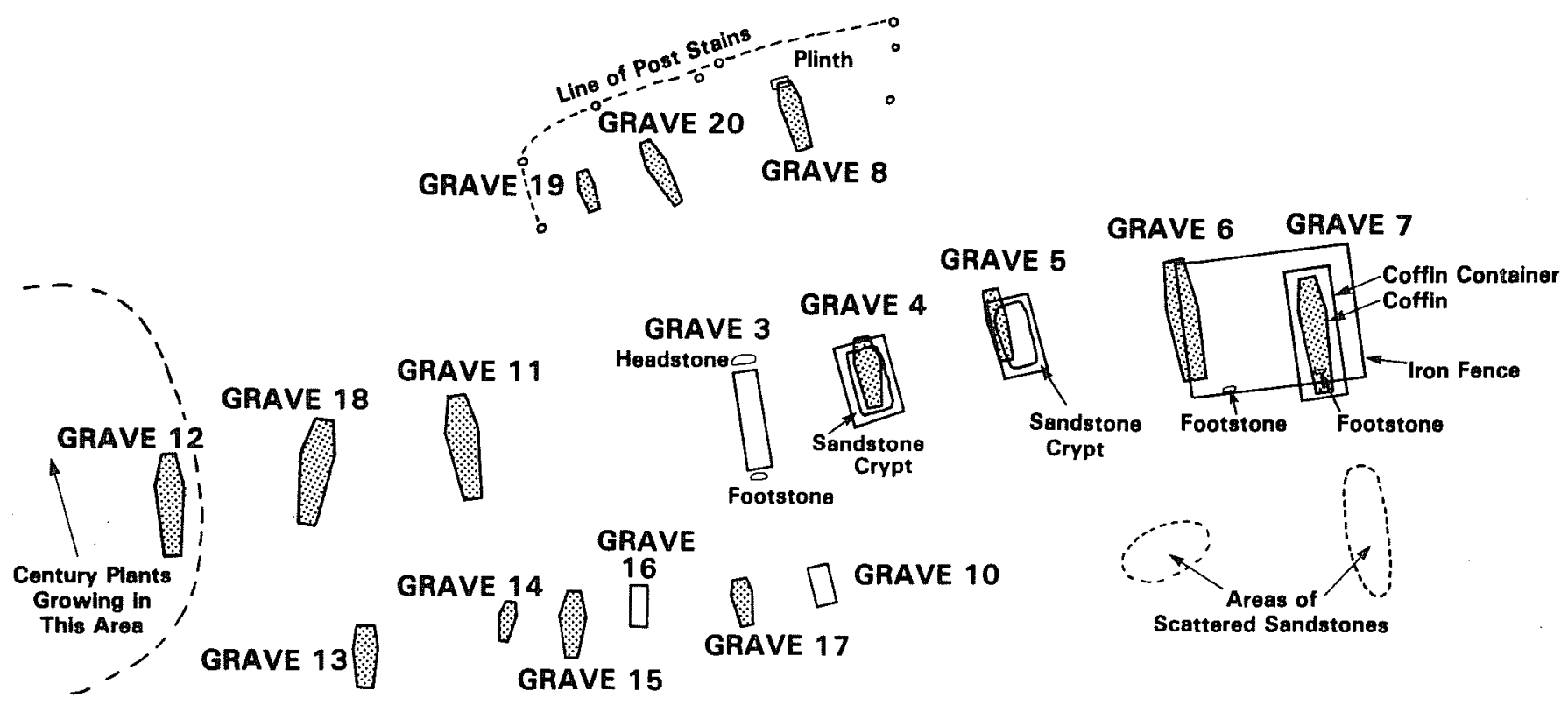

GRAVE 9

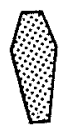

\section{PLAN OF BYRNE CEMETERY 41 MC 66}

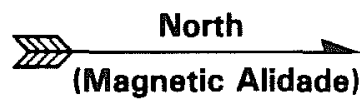

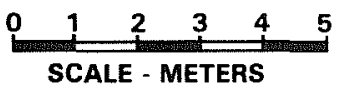

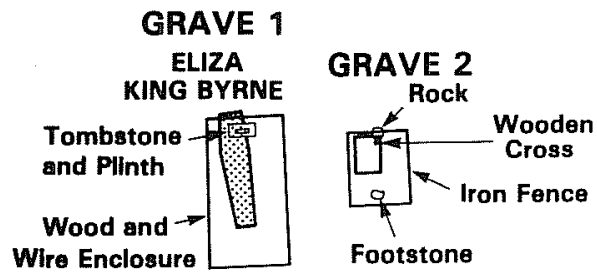

Figure 14. Map of Byrne Cemetery. 
Janet Stock on November 10. The foresight of the crew in mapping and photographing the site and the visible graves previous to the day that excavation was to begin also aided greatly the documentation during excavation. Coordination and accurate recording were assured by assigning certain functions to one individual throughout the operation. The graves were numbered in the order in which they were excavated, for the most part, and will be described in numerical sequence.

Grave 1. Grave 1 was surrounded by a wire fence supported by wooden posts and rails and marked by a stone set into a plinth at the west end of the grave (Fig. 15,a). The inscription, which faced toward the foot, or east end of the grave, read "Sacred to the memory of Eliza King Byrne, Born June 17, 1830, Died November 24, 1911, R.I.P." The stone measured $25 \times 45 \times 5 \mathrm{~cm}$ thick, and the plinth was $23 \times 32 \times 30 \mathrm{~cm}$ high (Fig. 16,c). After the enclosure was removed, the stone with plinth securely attached was removed and set aside. The overburden above the coffin was removed by the backhoe, and the remains were exposed by an archaeologist. Much of the lid of the hexagonal, wooden coffin was still preserved. The forearms of the individual were crossed at the waist. There was a black brooch of composition material with a brass pin for attachment at the throat. Fragments of a brass safety pin and a silver religious medal (see Appendix II) were found in the chest area, along with a small shell button, and another safety pin was at the waist. Small pieces of a fabric resembling unbleached muslin were stuck to the first pin. Larger fragments of black fabric were also present. A brown composition hair comb was situated beneath the skull. A small brass tack was driven into the bottom of the coffin in the area between the knees (Fig. 16,a,b).

The bones were well preserved, other than the crushing of the skull by the weight of the soil. Sex was assessed as female, judging by the virtual absence of brow ridges, the width of the greater sciatic notches, and the proportions of the sacrum.

Age of the individual at the time of death was thought to be 70 years or more because of the following observations. The lower teeth had all been lost at least a decade before death, resulting in a heavily resorbed mandible with a groove indicating the former presence of tooth sockets. Several of the cervical and thoracic vertebrae were ankylosed (grown together), probably a result of degenerative joint disorders rather than some traumatic event. The cranium displayed advanced endocranial and ectocranial synostosis.

The other joints appeared free of any osteoarthritic involvement. There was no indication of the cause of death.

The observations confirm the identification of this grave as that of Miss Eliza King Byrne. Mrs. Clara Dilworth Wyatt contributed the interesting information that it was customary in Aunt Eliza's time for a woman to pin a religious medal to her underwear with a safety pin, since she seldom was so fortunate as to have a chain on which to wear it. She was probably buried in her best black dress, with her hair gathered at the back of her head with an ornamental comb. The copper tack would have probably been one of a number of tacks which fastened a cloth lining to the inside of the coffin. 

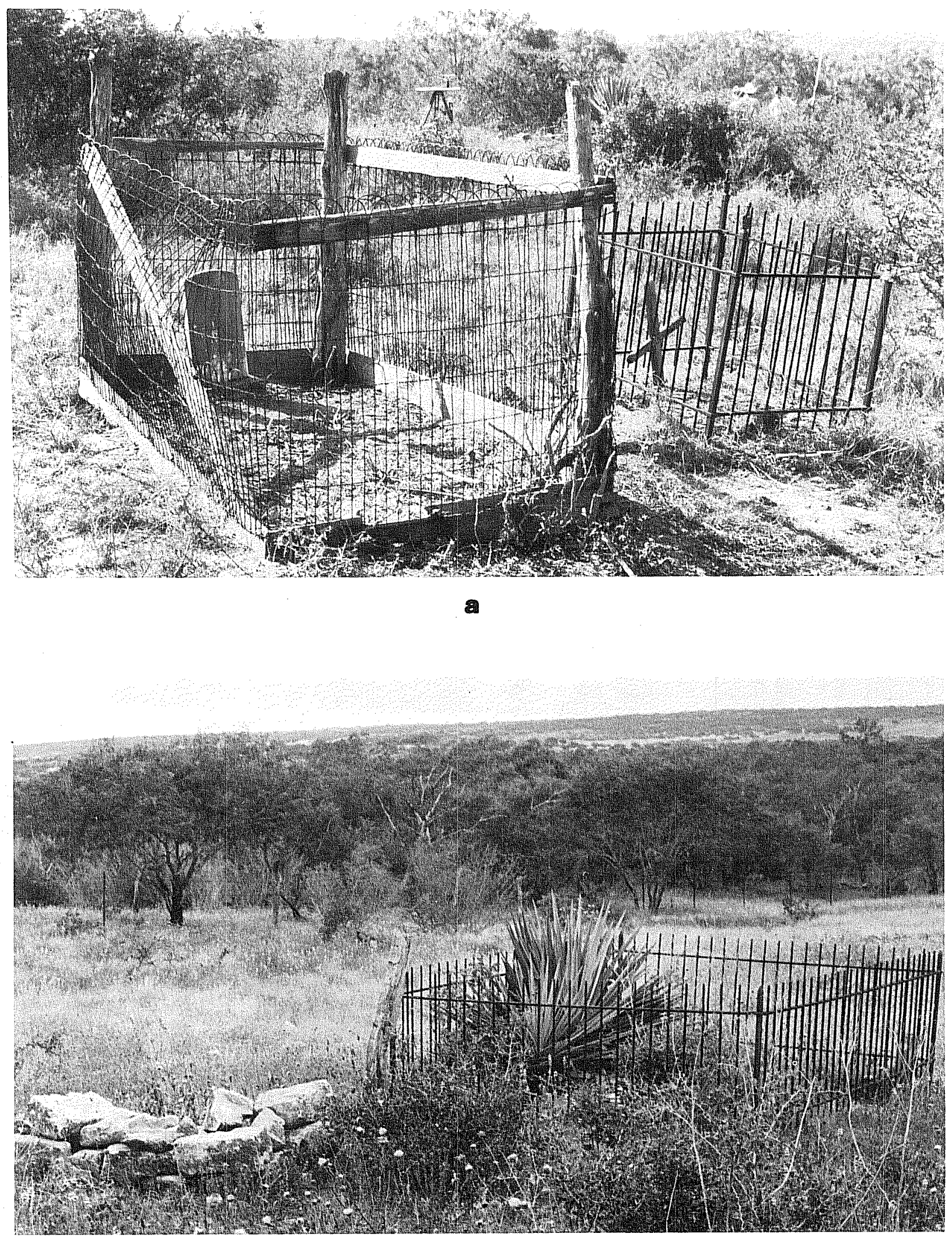

\section{b}

Figure 15. Views of Byrne Cemetery Before Excavation. a, Graves 1 and 2 looking west; $b$, fence enclosing graves of Dr. and Mrs. Dilworth and, to the left, crypt of Mary Calpernia, looking northwest. 

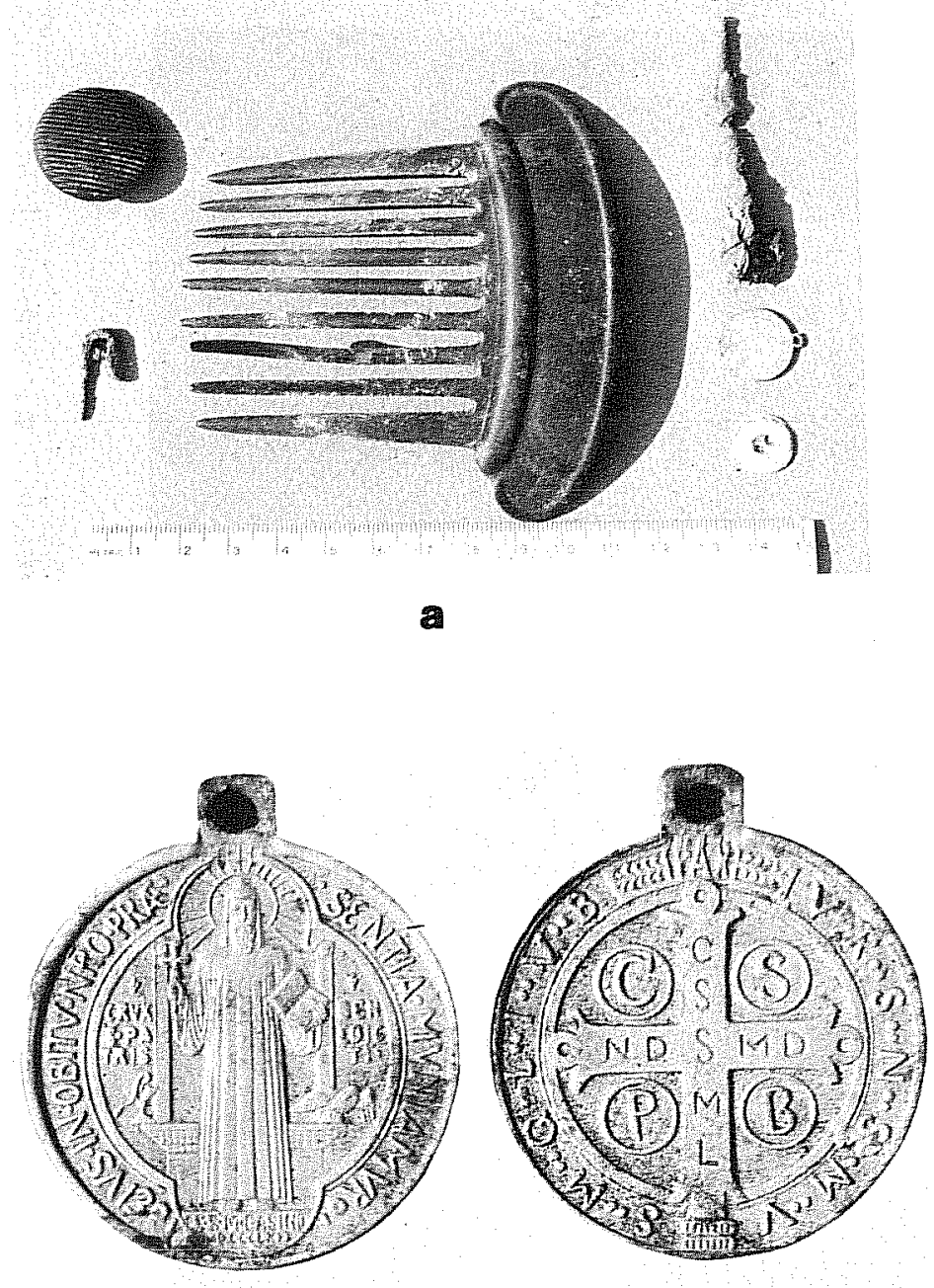

b

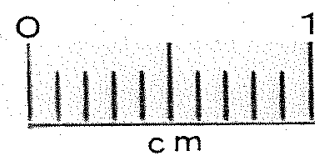

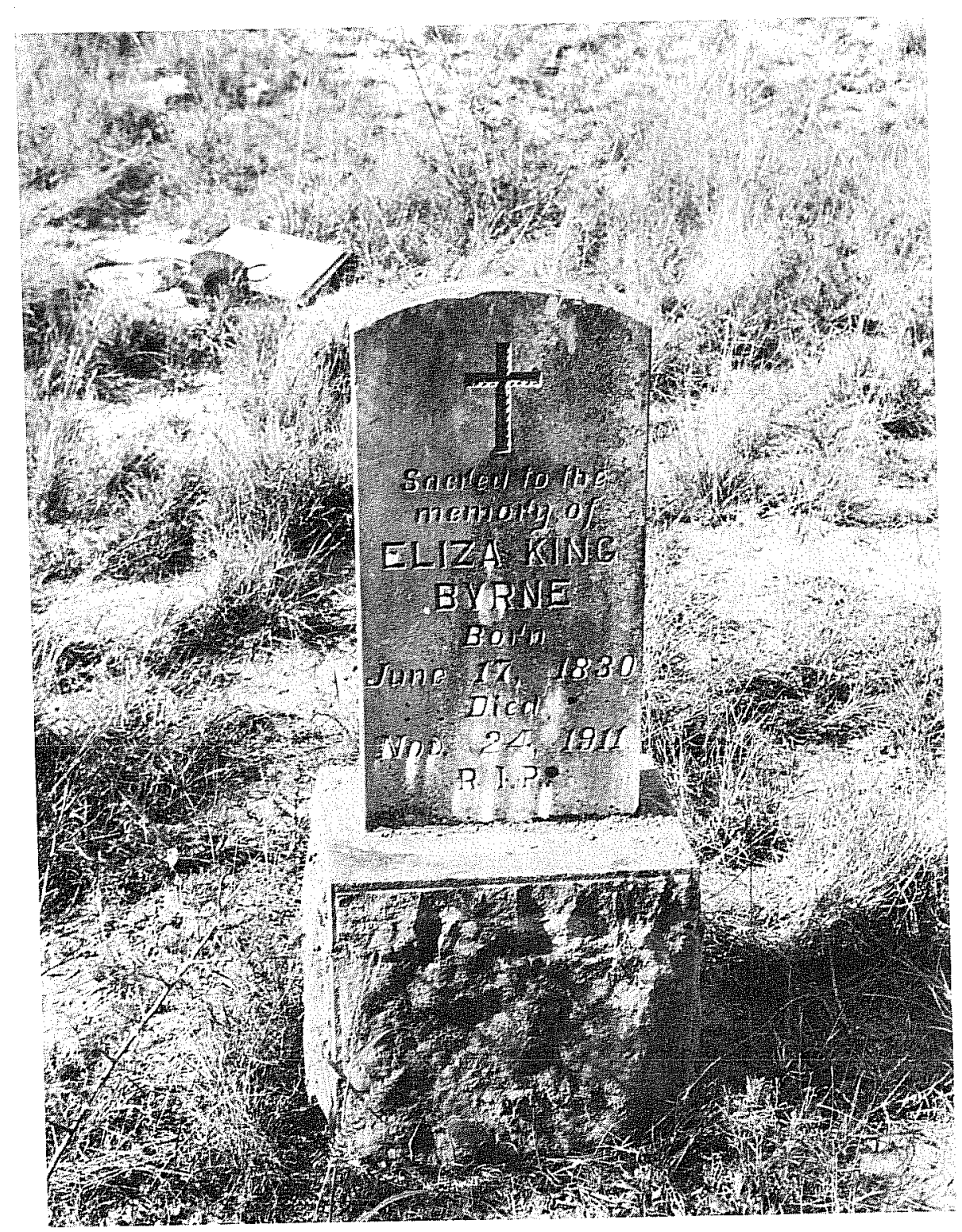

c

Figure 16. Details of Grave 1. a, artifacts from Eliza Byrne's grave; b, medal from Eliza Byrne's grave (obverse and reverse); c, Eliza King Byrne gravestone. 
Grave 2. The iron fence surrounding Grave 2 was removed, the wooden cross and crude fieldstone foot marker set aside, and the soil removed from above the coffin by the backhoe. The archaeologist found what appeared to be a double layer of wood making up the coffin lid which was attached with screws. The coffin was a rectangular box held together with wire nails and lined with fabric, fragments of which still clung to tacks in the sides. It had been set into an excavation in the poorly consolidated sandstone bedrock which was the exact size of the box.

The bones were very fragile and poorly preserved. The skull lay at the east end. The skeleton was that of an infant from birth to six months of age. The maximum diaphyseal length of the left humerus was $49 \mathrm{~mm}$. The shape and degree of development of the other bones observed are consistent with the development of the left humerus. The fragments of the cranial vault were brittle and paper-thin.

The left half of the mandible was examined. Tooth sockets were developing but none to the point of being crypts, and no sign of dental calcification was observed.

These observations would confirm the identification of the burial as that of a still-born infant (J. R. Henry, personal communication).

Grave 3. An unshaped fieldstone was set upright at either end of Grave 3. No markings were present which might help in identifying the occupant, but the distance between the stones suggested an adult burial. When the soil above the burial was removed, archaeologists discovered that the deceased was buried in a rectangular coffin rather than the hexagonal examples encountered in previous adult burials.

The skeleton was complete and well preserved. There were five $9.4 \mathrm{~mm}$ white glass buttons located between the chest and knees. The bones, including the skull and mandible, were intact. The lack of defined brow ridges, small mastoid processes, and the configuration of the mandible were suggestive of a female. The greater sciatic notches were neither distinctly male nor female. The 1 ong bones were robust, and the muscular insertions were well defined. The heads of the humeri and femora were large. The skull by itself would be classified as female, the pelvis as indeterminate and the long bones as "unquestionably" male. Therefore, the physical anthropologist could not be confident about assigning the skeleton to either sex.

The 2nd permanent molars were erupted and functional. There was no sign of the 3rd molars (likely agenic). All epiphyses were present and completely fused. Endocranial synostosis could not be examined. Ectocranial synostos is was not at all apparent, and dental attrition had produced only islands of dentine in the posterior teeth. Based on these observations, the age of this individual was estimated to be in the third or fourth decade of life (i.e., from 20 to 39 years of age).

There were no signs of pathology other than the loss of some anterior teeth and some caries. There was no indication of the cause of death. 
A visitor to Texas in 1854 remarked on the amount of hard, physical labor required of women in the frontier communities, "The women of the settlement by the absolute necessity of outdoor work had been rendered, it seemed to us, very masculine in character" (01msted 1978:167). One result of a lifetime of such labor could well be the development of robust musculature approaching that of a man.

Women's dress styles popular in the late 19th century and early 20th century often included a row of buttons up the front. In the 1920s, Aunt Mandy Yarbrough Walker, then an elderly lady, was described thus: "She always wore the same style dress which was a dark print of tiny check with a high neck, long sleeves and buttoned from neck to hem" (MCHBC n.d.:456). Numerous other family photographs in the same volume illustrate this fashion. The number of feminine traits found by the physical anthropologist added to the suggestion of feminine attire on the burial tend to persuade the author that this was probably the burial of a woman.

Grave 4. Grave 4 was the first of two identical stone crypts set side by side. It was constructed of large, flat slabs of local sandstone set on edge to form a rectangle and then topped with additional cut stones. It once had large flat slabs laid across the top as wel1. The latter had broken and fallen in, and many of the perimeter stones were out of place. There was no evidence for the use of mortar in the construction of the crypt. There were no marks on the stones identifying the occupant of the grave.

Once the stones had been moved away, and the soil above the coffin removed, the archaeologist found that a rectangular grave pit had been dug to the top of the basal bedrock, and then an excavation the exact shape and depth of the coffin was made down into the bedrock. The coffin was set into this hole.

The wooden lid had collapsed upon the burial. The bones were intact and well preserved. The hands were crossed over the pelvis. Diaphyses and epiphyses were in their correct anatomical position and were recognizable. Based on dentition, the estimated age at time of death was three years, too young to have acquired characteristics which would allow the evaluation of sex. No artifacts were found in the grave other than the nails and wood used in making the coffin. It seems very likely that this burial is that of Jasper Harrison, aged three years, who was buried in this vicinity in 1869 . His stone was recorded in 1977, but was not present when the author first visited the site in 1981 .

Grave 5. The crypt of Grave 5 was identical to that of Grave 4 (see Fig. 15,b). The burial was found to be in a rectangular coffin, the sides of which appeared to be slightly bowed inwards from the weight of the earth above. The bones were intact and in good condition. One hand was under the chin, the other along the side. The age at the time of death was established from dentition to be seven years; the sex was not discernible. One $1.4 \mathrm{~cm}$ white glass button lay on the right pelvis, but no other artifacts were found. There was no indication of the cause of death.

This was undoubtedly Mary Calpernia Dilworth, daughter of Dr. and Mrs. Dilworth, who died at the age of seven, not long after the family moved to Yarbrough 
Bend. The combination of the appropriate age and the location next to the Dilworths would seem to make this conclusion inescapable.

Grave 6 . Graves 6 and 7 were enclosed in a cast-iron fence. Two simple, unmarked footstones of local fieldstone set on edge and a large clump of yuccas at the opposite side marked the site.

When the fence had been removed and the vegetation cleared, the soil above the southernmost grave was excavated. About a foot above the top of the coffin, a few small bones began to appear, suggesting that the burial had been disturbed. As excavation proceeded, the presence of a large rodent burrow and numerous hackberry seeds identified the culprit as part of the natural order of things rather than human curiosity or cupidity. The bones of the lower extremities and the lower jaw were found to be in disarray due to the burrowing of the rodent, but the rest of the skeleton was in good order.

The skull was equivocal as to sex, with slight brow ridges and medium mastoids. The mandible, although incomplete because of disturbance, showed proportions and configuration that were indeterminate for sex. The shape of the greater sciatic notch seemed characteristically male. The long bones were gracile and would, under isolated circumstances, be classified as female. Based on the pelvic configuration, the physical anthropologist tended to classify this individual as male, but was not at all convinced of the correctness of this finding.

A11 epiphyses were present and completely fused, although there was a bit of an epiphyseal scar on the medial metaphysis of the right clavicle. The 3rd molars of the mandible fragment (sockets only) and the upper arcade (right only) were erupted. The upper $3 r d$ molar was functional; the upper left $3 r d$ molar seemed agenic.

The closure of the cranial suture was not at all advanced ectocranially. The pubic symphyses did not have the "billowing" appearance of early maturity. The vertebrae had sharp, crisp, we11-defined edges to the articulations. The estimated age at death was 25 to 35 years. There was no skeletal evidence of the cause of death.

The hands appear to have been folded across the waist. A large pair of scissors and a composition comb with decorative metal strips along the top were found between the upper chest and the left upper arm. No other artifacts were recorded.

The location of the grave, the general age of the individual, and the kind of artifacts present suggest that this was Mrs. Mary Elizabeth Lampkin Dilworth. The identification of the sex of the skeleton as male is not strongly argued by the physical anthropologist, so there is no clear contradiction with the identification as Mary Dilworth. It is interesting that this problem of sex determination should occur in two individuals in much the same age bracket, both of whom appear from other factors to be female. It is not known at present whether the two were related, although the close proximity of their graves suggests this possibility. 
Grave 7. Once the overburden had been removed, the archaeologist discovered that Grave 7 had been interred in a double casing. An outer, rectangular wooden box fastened with wire nails enclosed an inner, hexagonal coffin whose top was secured with decorative, zinc-topped screws (Fig. 17,b).

The skeleton was complete and very well preserved, the bone was in sound condition. The sex was assessed to be male, because of the robusticity of the bones, wel1-developed mastoids, the shape of the sciatic notches and the mandible, and in spite of rather slight brow ridges. The synostosis of the external sutures and tooth wear suggest an age in excess of 40 years.

There was extensive lipping of the cervical vertebrae and three mid-cervical vertebrae were ankylosed. Thoracic and lumbar vertebrae were not so heavily involved, suggesting that the lipping seen in the cervical region is a response to trauma rather than a concomitant of the aging process. There was no involvement apparent in the other joints.

The medial end of the right clavicle was abnormal, perhaps the result of the healing of an old injury. The upper right molars had been lost long before death, and the alveolus was completely healed over. There was moderate to heavy deposition of gingival calculus on the posterior teeth.

Fragments of a coarse weave material were preserved at the shoulder and pelvis. Metal buttons were found from the throat to the pelvis. Also found in the pelvic area was a button of composition material. A pair of low-cut, machinestitched shoes were on the feet. Splashes of yellow paint were visible on the left shoe. A fragment of shoe lining bore the remains of a machine-knitted sock.

This burial is without doubt that of Dr. George Anson Dilworth, who was buried in 1894 after suffering for two years with a "broken back." Since it was known that Dr. and Mrs. Dilworth had been buried in the fenced-in plot, our findings come as no surprise. The location of the graves, however, in reference to one another was interesting for a number of reasons. The Dilworth descendants were surprised to find that the burials were reversed in respect to their memory of the way the markers had been arranged. (The markers had disappeared by 1981.) The author was surprised to find that Dr. Dilworth was buried at the left hand of his wife, when southern folk tradition generally dictates that the husband lies to the right, or south of the wife (Jordan 1982:30). The project map of the cemetery shows clearly that the installation of the iron fence and head and footstones must have taken place some time well after the burial of Dr. Dilworth, since they are not accurately positioned over the graves. This would probably date the installation ca. 1900, perhaps even at the time of the burial of the Henry baby in 1913 when a similar fence was installed on that grave.

Grave 8. While clearing the brush in a search for additional graves, a stone plinth, marking Grave 8, was found to the west of Grave 4. Surface scraping in the area revealed the outline of the grave pit, which Mr. Henry recalled as once being the location of the marker for Charles Thomas Taylor. The plinth 

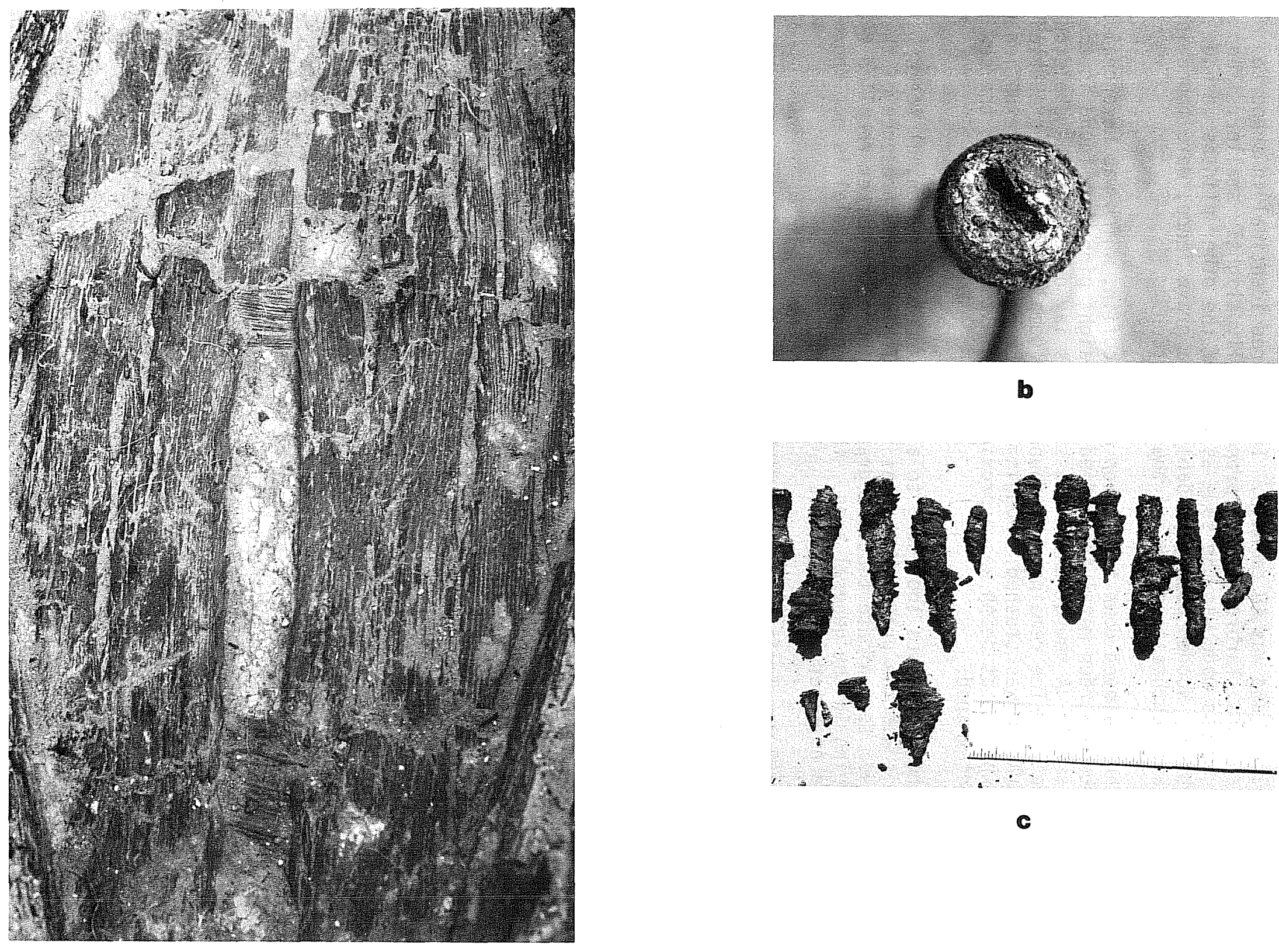

b

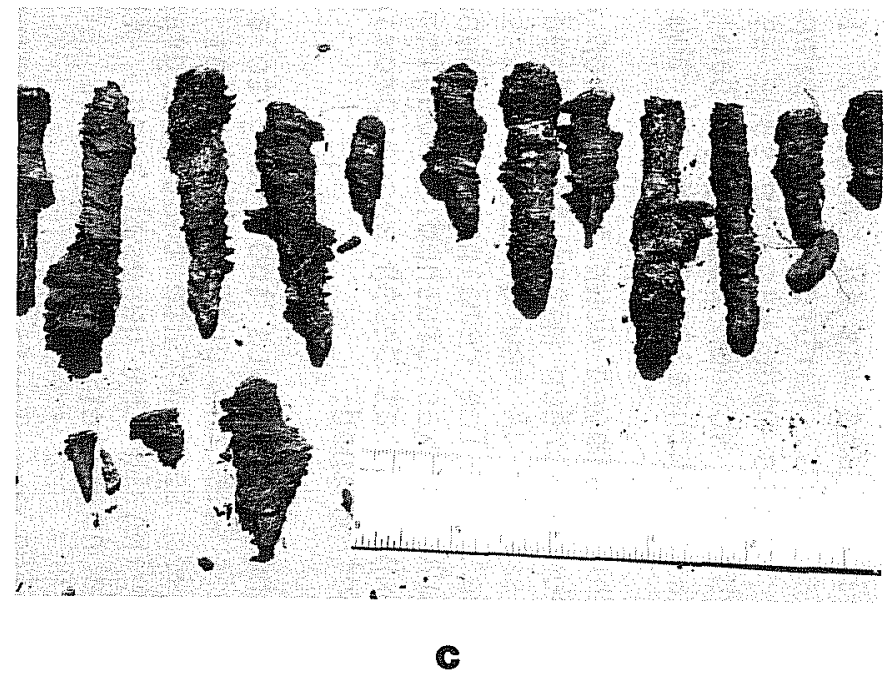

a

Figure 17. Burial Details. a, detail of coffin construction; b, screw from Grave 7; c, typical coffin nails. 
measured $23 \times 30 \mathrm{~cm}$ and was $18 \mathrm{~cm}$ high. It appeared identical in shape to those for $\mathrm{Mr}$. and Mrs. Yarbrough, but proportionally slightly smaller. The stone of which it was made was the same as that of the other plinths we had observed elsewhere. Wooden posts, probably from a grave fence, were found in the northwest and southeast corners of the excavation.

The soil was then removed down to the top of the coffin, which was hexagonal. Traces of corroded, green metal identified as straight pins were found in the region of the skul1. A row of white glass buttons lay on top of the skeleton from neck to waist. The remains were found to be complete and well preserved, although the cranium was crushed. Judging from the development and eruption of the dentition the age at death was approximately six to seven years; the sex could not be determined.

Although the individual was too young to allow sex determination, it seems likely that this was the grave of Charles Thomas Taylor. The presence of the plinth would seem to indicate that the grave once bore the marker recalled by $\mathrm{Mr}$. Henry as being in the general area. The date of this burial is not known, but it could be no later than ca. 1920 .

Grave 9. Grave 9 was located slightly to the east of the main group but appeared to be of the same time period. The coffin was hexagonal. The remains were complete and well preserved, with the hands crossed on the abdomen. No artifacts were found in the grave.

From the configuration of the greater sciatic notches, the sex was assessed as female. (Despite the fact that the innominate was unfused, the union of the ilium and the ischio-pubic ramus was articulated and the notch was, essentially, in its adult configuration.) The mastoids were not pronounced, the brow ridges were very slight.

None of the epiphyses of the long bones were fused, although all were present and well developed. The permanent dentition was erupted and functional, including the 2nd molar. The 3rd molars were unerupted, still within the crypt, and no sign of them could be seen above the line of the alveolus. The age was estimated to be 15 years, based principally on dentition.

The upper right 2nd premolar was agenic, and the upper right 2nd deciduous molar was retained. No other anomaly was observed.

Grave 10. Grave 10 was found to be that of an infant. The coffin was a rectangular box of which only the outline was preserved. The remains were in very fragile condition, but the skeleton was complete. There was a straight pin under the chin, and another over the chest. Here, as in Grave 2 (that of the Henry infant), the head was at the east end of the grave. This orientation was probably an error since the coffin was rectangular and, therefore, had no discernible head and foot when it came time for interment, rather than for any other reason.

The sex could not be determined. The lower dentition was examined (the upper not surviving removal from the matrix). The sockets for the deciduous incisors and lst deciduous molar were sharply defined although the tooth crowns were not 
preserved. The deciduous canine was still in its crypt. The age at the time of death would have been ca. six months. No pathology was observed nor any indication of the cause of death.

Grave 11. Grave 11 was found to contain a hexagonal coffin with what looked like a double layer of boards composing the lid, the upper layer perpendicular and the layer beneath parallel to the long axis of the coffin. Studying the field notes and photographs, the author is now convinced that this arrangement was evidence of the custom of laying boards across the grave pit above the coffin in an effort to prevent the weight of the soil from caving in the $1 \mathrm{id}$. This may also have been the case with Grave 2, where the 1 id appeared to be a double layer of boards.

The skeleton in the grave was found to be well preserved and complete. The hands were crossed at the waist. Three white shell stud buttons were found, one in the chest area and two in the pelvic area. Of these, two were composite studs of shel1 and metal, the third was of shell only and was slightly smaller in diameter. Also found in this grave was a zinc-headed screw for attachment of the lid, similar to the screw found in Grave 7.

The greater sciatic notches, gracile long bones, very slight brow ridges, small mastoids, and pointed mandible all are definitely feminine. One lower 3rd molar was erupting but not functional, the other erupted and functional. The medial clavicular epiphyses were not fused; the illiac crest of the innominate was fused. The proximal epiphyses of the ends of the femora and humeri bore epiphyseal scars of recent union. The distal femur and humerus were completely fused, as were all other epiphyses. Age was estimated at 18 to 19 years. No sign was found of the cause of death.

Grave 12. In Grave 12 rodent activity was evident, but there was no disturbance to the skeleton. The coffin was hexagonal. The bones were intact and sound, the skeleton well preserved. The hands were laid across the chest. No artifacts were noted.

The configuration of the greater sciatic notches, the gracile bones, the small mastoids, very slight brow ridges, and pointed mandible indicated a female.

The medial clavicular epiphyses were not fused; the 117 iac crest of the innominate was nearly fused. The 3rd molars were all erupted and functional. There were islands of dentine exposed on the lst molars. The age was convincingly estimated to be 21 years. There was no pathology or sign of the cause of death.

Grave 13. A hexagonal coffin of Grave 13 contained the bones of a juvenile, which were well preserved except that the skull was crushed. The sex could not be determined. There were no artifacts in the grave.

In the lower dentition, the 1st permanent molar was a crown in its crypt, the 2nd deciduous molar was about half erupted, and all other deciduous teeth were erupted and functional. The estimated age of the individual at death was 1 1/2 years. No apparent pathologies or abnormalities were seen, nor was there any sign of the cause of death. 
Grave 14. Grave 14 contained a sma11, hexagonal coffin of which there was Tittle remaining except the shape in the ground. The bones of the individual it contained were very fragile but the skeleton was complete and articulated, except for the skull which was crushed. Sex could not be determined. A smail straight pin was found in the center of the chest.

The dentition, although present, was disturbed so badly by even gentle brushing that no useful observations could be made. The skeleton was certainly that of an infant, however, probably of an age 0 to 6 months at the time of death. No observations of pathology were made, nor was there any evidence of the cause of death.

Grave 15. Grave 15 contained a sma 11, hexagonal coffin. The bones, except for the skuT7, were intact and in sound condition. The hands were crossed at the waist. No artifacts were found.

The individual was too young for sex determination. Only the crown of the lst permanent molar was calcified. The age at death was estimated at $11 / 2$ years. There was no sign of pathology, or of the cause of death.

Grave 16. A roughly shaped piece of sandstone set on edge marked the head of Grave 16. When this grave was excavated, the plan of the original grave pit was found to extend ca. $10 \mathrm{~cm}$ into the caliche subsoil. From this level, a hole had been dug in the exact shape of the coffin to a depth of $30 \mathrm{~cm}$. The sku11 was crushed, and the other bones were very fragile. One straight pin lay on the chest, another at the waist. The age at the time of death was estimated to be 0 to 6 months. There was no sign of pathology and none of the cause of death.

Grave 17. The coffin in Grave 17 had been hexagona1, but no wood remained. The grave contained an infant's skeleton in very fragile condition. The skull was crushed by the weight of the earth. No artifacts were recorded in this grave.

The skeleton was at a point of development about equal to that of Grave 14. The dentition seemed less developed than that of Grave 14, but the preservation of the bones was too poor to make any but the most general observations. The estimated age at death was 0 to 6 months. No observations of pathology were made, and there were no signs of the cause of death.

Grave 18. Grave 18 contained a hexagonal coffin of which much of the wood was preserved. The skeleton with in was well preserved and completely articulated. The hands were crossed over the waist. A single, white glass button lay in the chest area.

The greater sciatic notches, mandible, mastoids, brow ridges, and gracility of the bones were undoubtedly female. All epiphyses were closed, including the medial ones of the clavicles. The 3rd molars were erupted, functional, and facets of wear were apparent on the occlusal surface. Ectocranial synostosis was advanced enough to suggest an age of 35 to 40 years for this individual.

There was no joint involvement or other pathology, except for a rotted lower left lst molar with a perapical abscess. No sign was found of the cause of death. 
Grave 19. The sma11, hexagonal coffin in Grave 19 was preserved primarily as a shape in the bedrock, but a wood sample was taken. The bones within, although poorly preserved, were reasonably sound except for the skull which was crushed. The arms lay at the sides. No artifacts were found.

The individual was too young for sex determination. The age at time of death was estimated at 0 to 6 months. There was no sign of pathology, nor of the cause of death.

Grave 20. The coffin in Grave 20 was unusually narrow for its length. The grave pit had been dug into the bedrock about $15 \mathrm{~cm}$, thereupon a coffin-shaped hole was dug as in Grave 16. In this case, the lower hole was somewhat larger than the actual outline of the coffin. The bones were well preserved, but the skull was crushed. The hands lay at the sides.

At the left side were two small shell buttons, badly disintegrating. Judging from their condition, there could easily have been additional identical buttons which had disappeared.

The deciduous dentition was completely erupted and functional. The 1st permanent molar had a developed crown, the 2nd permanent molar had only the occlusal surface calcified. The age at death was estimated to be four years. There were no signs of pathology and no indication of the cause of death.

\section{Discussion}

The burials in the Byrne Cemetery appear to be primarily related to the Yarbrough Bend community of ca. 1858 to 1880, judging from the names involved in the identifiable graves. It is interesting to note that the post-1900 Byrne family burials cluster a polite distance away from the main grouping. Although $\mathrm{Mr}$. Henry recalled one or two additional graves in the area between the two groups, we were unable to find any indication of them despite careful scraping and examination of the ground surface and subsurface.

Jordan (1982:33) remarks on the traditional subdivision in Texas folk cemeteries into family plots. This circumstance might account for the groupings seen in the western section of the cemetery (Fig. 14), with the Dilworths somewhat separated to the north of one row, and a cluster apparently surrounded by a wooden or wire fence on wooden posts to the west. The pathetic row of infant burials in the center, however, could well involve a number of related families and certainly dramatizes the high rate of infant mortality during the 19 th century.

The fact that relatively straight, separate rows of graves were kept would suggest that some form of marker was used, perhaps of wood such as the cross on the Henry baby's grave. At the very least, mounds of earth would have marked grave locations for a period after burial. It is not known whether there was ever an attempt to keep the cemetery cleared or delimited in a formal way. As mentioned, no evidence was found for a surrounding wall or fence. The comparative depth of the graves (Table 1) suggests that there was never a complete 
TABLE 1. SUMMARY OF DATA ON YARBROUGH AND BYRNE CEMETERY BURIALS

\begin{tabular}{|c|c|c|c|c|c|c|c|c|c|c|c|c|c|c|}
\hline \multirow[b]{2}{*}{ Cemetery } & \multicolumn{2}{|c|}{ Humerus* } & \multicolumn{2}{|c|}{ Radius* } & \multicolumn{2}{|c|}{ U1na* } & \multicolumn{2}{|c|}{ Femur* } & \multicolumn{2}{|c|}{ Tibia* } & \multicolumn{2}{|c|}{ Fibula* } & \multirow{2}{*}{$\begin{array}{l}\text { Age in } \\
\text { Years }\end{array}$} & \multirow[b]{2}{*}{ Sex } \\
\hline & $\mathrm{L}$ & $\mathrm{R}$ & $L$ & $\mathrm{R}$ & L & $R$ & L & $\mathrm{R}$ & $\mathrm{L}$ & $\mathrm{R}$ & & $\mathrm{R}$ & & \\
\hline \multicolumn{15}{|l|}{ YARBROUGH } \\
\hline Grave 1 & & & & & & & & 424 & 325 & & 338 & & $40+$ & $F$ \\
\hline Grave 2 & & & & & & & & 209 & & 168 & & 166 & 5 & -- \\
\hline Grave 3 & & & & & & & & 438 & & 375 & & 370 & 88 & M \\
\hline Grave 4 & & & & & & & & 298 & & 250 & & 252 & 11 & - \\
\hline Grave 5 & & & & & & & & 270 & & & & 229 & 8 & -- \\
\hline Grave 6 & & & & & & & & 418 & & 355 & & 345 & $30-40$ & $\mathrm{~F}$ \\
\hline \multicolumn{15}{|l|}{ BYRNE } \\
\hline Grave 1 & & & & & & & 415 & & & 325 & & & 81 & $F$ \\
\hline Grave 2 & 49 & & & & & & & & & & & & 0 & -- \\
\hline Grave 3 & & & & & & & 440 & & 352 & & & & $30-40$ & $(F)$ \\
\hline Grave 4 & 121 & & 100 & & 108 & & 176 & & 134 & & 137 & & 3 & (M) \\
\hline Grave 5 & 176 & & 139 & & & & 238 & & & 196 & & 197 & 7 & $(F)$ \\
\hline Grave 6 & & & & & & & & 450 & 362 & & & 353 & $25-35$ & $(F)$ \\
\hline Grave 7 & & & & & & & & 498 & 410 & & & & 69 & M \\
\hline Grave 8 & 158 & & & & 130 & & 199 & & 174 & & & & $6-7$ & (M) \\
\hline Grave 9 & & & & & \multicolumn{6}{|c|}{ no measurements recorded } & & & 15 & $F$ \\
\hline Grave 10 & & 69 & & 53 & & & 78 & & 66 & & & & $1 / 2$ & - \\
\hline Grave 11 & & & & & & & 429 & & & 361 & & 350 & $18-19$ & $F$ \\
\hline Grave 12 & & & & & & & & 430 & & 352 & & 348 & 21 & $\mathrm{~F}$ \\
\hline Grave 13 & & 119 & & 96 & & 105 & & 150 & & & & 128 & $11 / 2$ & - \\
\hline Grave 14 & & & & & & & & 78 & & 68 & & 62 & $0-1 / 2$ & -- \\
\hline Grave 15 & & 136 & & 100 & & 110 & & 172 & & 148 & & 144 & $11 / 2$ & -- \\
\hline Grave 16 & 58 & & & & & & 78 & & 68 & & 65 & & $0-1 / 2$ & -- \\
\hline Grave 17 & 65 & & 55 & & 61 & & 76 & & & 62 & & & $0-1 / 2$ & -- \\
\hline Grave 18 & & & & & & & 421 & & & 341 & & 330 & $35-40$ & $\mathrm{~F}$ \\
\hline Grave 19 & & & & 59 & & 67 & 90 & & 77 & & & & $0-1 / 2$ & -- \\
\hline Grave 20 & 148 & & 117 & & 126 & & 210 & & 181 & & 180 & & 4 & - \\
\hline
\end{tabular}

* measurements in $\mathrm{mm}$

NOTE: (M) (F) Sex determination was based on evidence other than skeletal. 
cleaning and scraping away of the grass on a periodic, perhaps annual basis, such as Jordan (ibid.:14-16) suggests was popular in the South and in rural Texas. If denuded, the sloping ground would have rapidly eroded away, the accumulated slope wash making the northern, downslope graves deeper than those to the south, and considering the time difference between their burials, Mrs. Dilworth's grave is somewhat deeper than her husband's.

The choice of a scenic location on a hil1side bears out Jordan's (1982:33) observation that such a practice is almost universal. He traces it back to the veneration of high places, which predates Christianity and is found in most religions around the world. The author has noted this custom in numerous other Texas communities. The town cemetery for Tilden, started at about the same time as the Yarbrough and Byrne Cemeteries. Appropriately named Hill Top Cemetery, it is situated on a hill overlooking the town.

\section{OBSERVATIONS}

\section{Cemeteries}

The traditional definition of a cemetery includes any piece of ground set apart for burial. We have taken the liberty, then, of referring to a 11 the various types of interments involved in this project as cemeteries. The average person, however, would probably visualize a large area in or near a town which contains many separate graves marked with various types of markers and representing many different families. Those raised in rural areas might also think of small, fenced plots on individual farms where family members are buried. During the 17th and early 18th century, in the northeastern United States, there were generally small burial grounds, often directly connected with the local church. These were literally packed with burials, often several to a grave or one dug through an earlier one with comparatively little regard to keeping track of the individual. Toward the end of the 18th century the custom of individual burial in small family plots was begun. It was not until the early 19 th century that the modern cemetery with designated lots first appeared (Deetz 1977:90).

The Yarbrough and Byrne Cemeteries would appear to be examples of a survival into the last half of the 19th century of the tradition of the family cemetery. Since Yarbrough Bend was, for the most part, one large extended family, burials seem to have been made in one or the other cemetery indiscriminately, although it appears that the Byrne Cemetery was more often used, and by a wider group of people. It may be that the Yarbrough Cemetery was 1imited primarily to Yarbroughs and their closest relatives, and it may have been used for a much shorter time period. At the same time that these small plots were being used, there developed in the town of Tilden two public cemeteries. One was the Boot Hill Cemetery (Fig. 18,a). This was primarily used, as were other such cemeteries in Texas (see Fox 1976:22-32), for strangers and gunfighters, most of whom met violent deaths, or for temporary burial of citizens who were later moved to family plots elsewhere. The other, Hill Top Cemetery (Fig. 18,b), contains the graves of local citizens, many of them related in numerous ways to the original Yarbrough Bend settlers. Here one finds markers and crypts, arranged in family plots, giving the impression of the Byrne Cemetery only on a 
Coffins

A11 of the coffins which we examined were made of wood, and the great majority were the traditional hexagonal "toe pinchers" which were widest at the shoulders and narrowed toward the head and foot. A few rectangular coffins, which came to be called caskets, represent a custom which began about 1850 (Blakely and Beck 1982:188; Jones 1967:75). The very smallest infants (Graves 2, 10, and 16 , Byrne Cemetery) were also in rectangular boxes.

It is not known when coffins first came into use in Texas. They were not used in Spanish times, to judge from 18th-century burials excavated in the San Antonio area (author's personal experience). By the early 19th century, however, hexagonal wooden coffins were in vogue in San Antonio (see Kendall and Perry 1974:27 and 83). 01msted (1978:319) reported the first use of a coffin in Eagle Pass as late as 1853.

Analys is of 20 wood samples taken from coffins in the Yarbrough Bend and Byrne Cemeteries indicates that all were of pine (see Appendix I). The exact species could not be determined, but it was possible to narrow the possibilities to long leaf, loblolly, or short leaf pine. These are all southern species found in eastern Texas and throughout the southeastern pine forests. This was something of a surprise, since it was anticipated that local woods were used in coffin making. Historical research soon revealed, however, that lumber was being imported into south Texas through the port of St. Mary's on Copano Bay from the time of its founding in the 1850s (Neighbors 1942:23). Captain Frederick Augustine piloted an ocean schooner loaded with "Florida long leaf lumber" over the bar and to St. Mary's in 1868 (ibid.:24). Lumber had also been imported into Indianola for a number of years prior to the founding of Yarbrough Bend. In October 1850, seven vessels were running regularly from Mobile and Pensacola carrying only lumber (Malsch 1977). From Indianola lumber was hauled inland by teamsters.

In 1851, John Martin moved his family from Liberty County to the vicinity of St. Mary's. His son, James M. Martin, owned a lumberyard in St. Mary's for many years (MCHBC n.d.:67) shipping his wares to Beeville, Oakville, and Tilden. In 1870, several members of the Martin family moved to the Tilden area and became ranchers (ibid.:325). It appears that there was a great deal of contact between St. Mary's and McMullen County, and that lumber for coffins, along with lumber for building houses and other structures, probably came from that port.

It is not known who made the coffins. Traditionally in most small communities a coffin was made to fit the individual when one was needed. There are two specific craftsmen known who could conceivably have been coffin makers for the Yarbrough Bend settlement. Green Alford, one of the original settlers of Tilden, was a carpenter who received payment from the county for making coffins for paupers. Records show they were made of pine and lined with cheesecloth (MCHBC n.d.:415). Another possibility was Peter Harrison who is identified in the 1870 census as a carpenter. Little else is known about him except that his infant son is buried in the Bryne Cemetery, and his wife is reputed to be one of the burials in the Yarbrough Cemetery. He was, therefore, a member of the Yarbrough Bend community and would probably have been more intimately 
involved in affairs of that group. However, by 1880 (USDI 1880) Harrison is no longer present, and his wife is living with her son-in-law on the Wheeler Ranch.

Making a coffin was not a simple job, and required some knowledge of wood working. Clark (1974:228) describes the laborious job of shaping the sides by cutting triangular grooves halfway through the thickness of the board and pouring boiling water over the wood to facilitate bending it into shape. Long steel tacks were used to hold the coffin together. These rusted into the coffin wood in such a characteristic manner (Fig. 17, C) that an alert archaeologist can recognize a coffin nail and predict the presence of a burial even where one is not expected to be found (see Fox 1977:7). The top and bottom were generally made three boards wide. At the Byrne Cemetery it was observed that the bottom of the coffin was sometimes reinforced by three strips nailed across the outside (Fig. 17,a), one of which went across the widest dimension.

\section{Grave Markers}

Permanent stone grave markers inscribed with names and dates were infrequent in the Yarbrough Bend cemeteries. They may not have been installed until after most of the original settlers had left the area, being intended as a means of preserving grave locations and identifications as well as honoring the memory of the deceased. Of the nine grave markers reported to once have existed for all five cemeteries, only five were still there when we arrived. This is hardly a sufficient sample to draw any sweeping conclusions about style and construction. None of the ones examined bore symbols or decoration of any sort beyond the simple inscriptions of names and dates and a short phrase. The carving all appears to be hand-done. All gravestones were made to set into socketed plinths which held them securely upright in the ground. Since there were no plinths on the Dilworth graves, we suspect that whoever removed the stones took the plinths as we11, perhaps because they were too securely cemented to loosen them.

One wooden marker was found--a simple cross on the grave of the Henry infant in the Bryne Cemetery. Wooden markers are a long-standing tradition across the South (Jordan 1982:41) and were probably used on most of the Yarbrough Bend graves. They were inexpensive and could be made and installed by the immediate family. Gradually these markers rot away and disappear, and, unless replaced, the location and identification of the grave are lost. This timehonored custom of marking graves with wooden crosses is still evident today on numerous Mexican-American graves in the Hill Top Cemetery as well as in others the author has seen across south Texas.

Simple, unmarked fieldstones were used on a number of the graves. These have the advantage of being permanent and relatively inconspicuous so as not to attract vandalism. Unfortunately, they do not aid in identifying the occupant of the grave. Such use of unmarked local stone is widespread in Texas, and the custom probably is as old as the use of wooden markers.

Stone crypts appear to have been popular in the United States during the late 19 th century. Actually the ones used in Texas are "false crypts," since they 
cover below-ground interments rather than containing the remains above ground as in southern Louisiana. Jordan (1982:18-19) notes the presence of false crypts in cemeteries in Kentucky and South Carolina as we 11 as in east Texas, which suggests a widespread tradition in this custom as well. We found some form of vaultlike grave cover at each cemetery in Yarbrough Bend. They ranged from a simple cairn over the Taylor and Morris grave to the more sophisticated, vaulted structures in the Morgan Cemetery.

\section{Fences}

Of the cemeteries we examined, all but the Byrne Cemetery had or once had some sort of delimiting fence or wall. This could have been to protect the area from the trampling of livestock as well as to indicate the limits of the area. Within the Byrne Cemetery there were both wooden and iron grave fences. of the two, the wooden ones are probably older. The custom of fencing graves was common throughout Texas in late 19th-century cemeteries.

\section{Burial Customs}

In order to gain a better understanding of the burials at Yarbrough Bend, the author searched for descriptions of burial customs, both in south Texas and in the areas from which the Yarbrough Bend families came. There were occasional bits of information from Tilden informants and in the McMullen County History, but by far the most helpful descriptions came from interviews with elderly people in Georgia (Wigginton 1973:304-323). Since the latter did not disagree with any of the Texas accounts and seemed to tie them into a coherent whole, the following account is based primarily on Wigginton's book.

When a person died, relatives were notified, one of the neighbors immediately began construction of a coffin, and the body was washed and dressed for burial, usually by members of the family. By the time the coffin was ready, family and friends had gathered at the home of the deceased. It was customary for a number of them to sit up all night with the body, as a mark of respect.

Burial was usually the next day, since there was no embalming. Often the preacher did not live in the local town but rode through on a regular circuit. In this case, friends and family would bury the deceased, and a memorial service would be held the next time the preacher came (Roberts 1950:160). Digging and filling of the grave were done by friends and neighbors.

The coffin was made to the size of the individual, often of wood specially put aside for the purpose. It was lined with white cloth padded with cotton or wood shavings, and held down with carpet tacks. Black cloth was sometimes used for adults. For tiny infants, a small rectangular box was lined and padded with cotton.

The use of pine for the coffins was probably not so much a matter of preference as what was available and inexpensive at the time. There may be a deeper significance here, however. In the early Xian church, pine cones were a symbol of life everlasting, likely because the trees were evergreen. Pine for coffins 
may be a survival of the tradition (Wesolowsky, personal communication). Our findings corroborate the folk stories in respect to the individual design and construction of coffins, the way infant coffins were made, and the custom of lining them with cloth held down with tacks. Although fancy metal handles and decorative screws and tacks were available to be used throughout the period of these cemeteries (McReynolds 1981:93), in only two cases was any such "modern" object seen, and then only in a modest practical way. This could, of course, reflect conservatism, convenience, or poverty.

Grave Inclusions in Yarbrough Bend

To judge from the number of graves that contained buttons, it appears that it was customary in Yarbrough Bend to bury people in their clothing. There were, however, a significant number of graves which had no such indication. Many of these burials had evidence of straight pins, which may have been used to secure or tailor a shroud or winding sheet. This was especially obvious in the Yarbrough Cemetery, where no evidence of clothing was found. We could find no particular reason for this difference.

There were few other inclusions in the coffins. The scissors and comb buried with Mrs. Dilworth may very we11 have been an accidental inclusion which occurred when the family was preparing the body for burial. Occasional tacks were surely an indication of the securing of the coffin lining.

\section{SUMMARY AND CONCLUSIONS}

Altogether, 34 graves were relocated during this project. The circumstances of burial ranged from hasty and impromptu in an isolated spot, in the case of the Morris and Taylor burials, to formal and traditional in a cemetery location. The burials appear to date from ca. 1860 to 1913, most of them within the time span of the existence of the Yarbrough Bend community (ca. 1858 to 1880). The individuals ranged in age from newborn to advanced maturity, and showed a remarkable lack of pathology other than what may be some form of anemia in the Yarbrough Cemetery and a general loss of dentition in the adults which seemed to increase with the advancing age of the individual. The size of the sample and the relatively short time period involved allow a number of observations to be made about the customs observed at Yarbrough Bend in regard to death and burial.

Jordan (1982:6-7) has remarked that rural cemeteries are excellent places to study the culture of an area, since they preserve archaic customs and practices which have become traditional through long use. In this particular case, rather than searching as Jordan did in his study for the origins of the customs observed, we recorded evidences of burial traditions which can be related directly to those recounted by elderly people in the areas from which the Yarbrough. Bend settlers came. Many of the hints and suggestions of such customs recorded during the examination and analysis of these burials can be confirmed and somewhat enlarged upon by referring to local reminiscences contained in the McMulien County History and those from other south Texas communities as we11. It appears that the people of Yarbrough Bend brought 
with them customs evolved over many generations throughout the southern United States. They clung to their time-honored customs and attitudes toward death and burial altering them 7ittle, if at all, during the late 19 th century.

0ther than an occasional rectangular coffin, we saw very little evidence of difference in customs, except a suggestion that some individuals may have been buried in shrouds rather than fully clothed.

When the Yarbrough Bend families moved to Tilden and a different way of life in town, their customs undoubtedly gradually changed, and burial in the old cemeteries ceased, except for an occasional, more conservative family or individual who consciously chose the old, traditional locale.

We feel that this was a most useful and worthwhile project. In the process of completing it, we not only compiled much information which will be useful to other archaeologists who are faced with a similar project, we also acquired a great deal of information about Yarbrough Bend families. The latter information is directly applicable to interpretation of the historic house sites in the Choke Canyon Reservoir (Fox n.d.).

\section{REFERENCES CITED}

Blakely, R. L. and J. A. Beck

1982 Bioarchaeology in the Urban Context in Archaeology of Urban America. In The Search for Pattern and Process, edited by Roy S. Dickens, Jr.:175-207. Academic Press, New York.

Brinckerhoff, S. B.

1972 Metal Uniform Insignia of the Frontier U.S. Army, 1846-1902. Arizona Historical Society, Museum Monograph 3. Tucson, Arizona. Second Edition.

1976 Boots and Shoes of the Frontier Soldier, 1865-1893. Arizona Historical Society, Museum Monograph 7. Tucson, Arizona.

Brothwe11, D. R.

1965 Digging up Bones. The Excavation, Treatment and Study of Human Skeletal Remains. Second Edition. Trustees of the British Museum, London.

Carter, E. S. and C. S. Ragsdale

1976 Biegel Settlement: Historic Sites Research, Fayette Power Project, Fayette County, Texas. Texas Archeological Survey, The University of Texas at Austin, Research Report 59. 
Clark, T. D.

1974 Pills, Petticoats, and Plows, The Southern Country Store. University of Oklahoma Press, Norman.

Coffin, M. M.

1976 Death in Early America. Thomas Nelson, Inc., Nashville.

Collins, M. B., T. R. Hester, and T. S. Ellezy

n.d. Excavations at Resaca de la Palma, a Mexican War Cemetery Site (41 CF 3), Cameron County, Texas. Notes on file, Texas Archeological Research Laboratory, The University of Texas at Austin.

Corps of Engineers, U.S. Army

1920 Tactical Map, Texas Mikeska Quadrangle. Copy on file, Center for Archaeological Research Laboratory, The University of Texas at San Antonio.

Day, J. H.

1937 The Sutton-Taylor Feud. Sid Murray \& Sons, San Antonio.

Deetz, J.

1977 In Small Things Forgotten, The Archeology of Early American Life. Anchor Press/Doubleday, Garden City, New York.

Dobie, J. F.

1981 A vaquero of the Brush Country. University of Texas Press. Reprinted by arrangement with Little, Brown and Company, Boston.

Everett, $D$.

1981 Historical Resources of the Choke Canyon Reservoir Area in McMullen and Live Oak Counties, Texas. Center for Archaeological Research, The University of Texas at San Antonio, Choke canyon Series 2.

Fox, A. A.

n.d. Excavations at Historic Sites in the Choke Canyon Reservoir, South Texas. Center for Archaeological Research, The University of Texas at San Antonio, Choke Canyon Series 10. In preparation.

1976 Archaeological Investigations at Fort Griffin State Historic Park, Shackelford County, Texas. Center for Archaeological Research, The University of Texas at San Antonio, Archaeological Survey Report 23. 
Fox, A. A. (continued)

1977 The Archaeology and History of the Spanish Governor's Palace Park. Center for Archaeological Research. The University of Texas at San Antonio, Archaeological Survey Report 31.

Gilmore, K. K.

1969 The San Xavier Mission. A Study in Historical Identification. State Building Commission, Archeological Program, Report 16. Austin, Texas.

Ha 11, G. D., S. L. Black, and C. Graves

1982 Archaeological Investigations at Choke Canyon Reservoir, South Texas: The Phase I Findings. Center for Archaeological Research, The University of Texas at San Antonio, Choke Canyon Series 5.

Jones, B.

1967 Design for Death. Bobbs-Merri11 Co., Inc., New York.

Jordan, T. G.

1982 Texas Graveyards, A Cultural Legacy. University of Texas Press, Austin.

Kenda 11, D. S. and C. Perry

1974 Gentilz, Artist of the Old Southwest. University of Texas Press, Austin.

Lynn, W. M., D. E. Fox, and N. O'Malley

1977 Cultural Resource Survey of Choke Canyon Reservoir, Live Oak and McMullen Counties, Texas. Office of the State Archeologist, Texas Historical Commission, Archeological Survey Report 20.

Malsch, B.

1977 Indianola - The Mother of Western Texas. Shoal Creek Publishers, Austin.

McMullen County History Book Committee (MCHBC)

n.d. McMullen County History. No publisher.

McReynolds, M. J.

1981 Archeological Investigations at the Laredo Cemetery Site

(41 WB 22), Webb County, Texas. Prewitt and Associates, Inc., Reports of Investigations 11. Austin, Texas. 
Montgomery Ward \& Co.

1969 Catalogue No. 57, Spring \& Summer, 1895. Dover Publications, Inc., New York.

Neighbors, C. Y.

1942 The 01d Town Saint Mary's on Copano Bay and Some Interesting People Who Once Lived There. Masters Thesis, Southwest Texas State Teachers College. San Marcos.

Newcomb, W. W., Jr.

1958 The Skeleton of Yellowhouse Canyon. Texas Memorial Museum, Museum Notes 8 . Austin.

01 msted, F. L.

1978 A Journey Through Texas, Or, A Saddle Trip on the Southwestern Frontier. University of Texas Press. Barker Texas History Center Series 2. Reprint of the 1857 edition published by Dix, Edwards, New York.

Puckle, B. S.

1926 Funeral Customs Their Origin and Development. T. Werner Laurie Ltd., London.

Roberts, B.

1950 Springs From The Parched Ground. Hornby Press, Uvalde.

Roemer, E., Jr.

1981 The 1979 Archaeological Survey of Portions of The Choke Canyon Reservoir in Live Oak and McMullen Counties, Texas. Center for Archaeological Research. The University of Texas at San Antonio, Choke Canyon Series 4.

Schuetz, M. K.

1968 Archeology of Mission San Juan Capistrano, San Antonio, Texas. Vol. I. State Building Commission, Archeological Program, Report 10. Austin, Texas.

1969 Description of the Artifacts and Ethno-History of the Coahuiltecan Indians. The History and Archaeology of Mission San Juan Capistrano, San Antonio, Texas. Vol. II. State Building Commission, Archeological Program, Report 11. Austin, Texas.

1974 The Dating of the Chapel at Mission San Juan Capistrano. Texas Historical Commission, Special Report 12. 
Suhm, D. A.

1962 The White Site: A Historic Indian Burial in Yoakum County, Texas. Bulletin of the Texas Archeological Society 32:85-119.

United States Department of the Interior, Office of the Census (USDI)

1870 The Ninth Census, 1870. Returns of Schedule One, Population. Webb County, 23 August 1870.

1880 The Tenth Census, 1880. Returns of Schedule One, Population. Webb County, 13 July 1880.

Returns of Schedule Two, Agriculture. Webb County, 11 June 1880.

Wigginton, E. (editor)

1973 Foxfire 2. Anchor Press/Doubleday, New York.

Wood, A. K.

1971 Texas Coastal Bend: People and Places. Naylor Company, San Antonio.

Word, J. H. and A. A. Fox

1975 The Cogdel1 Burial in Floyd County, Texas. Bulletin of the Texas Archeological Society 46:1-64.

Yates, C. H.

1977 Three Cemeteries Associated with Texana. In Texana: Excavations at a Nineteenth Century Inland Coastal Town, Jackson County, Texas, by Marsha F. Jackson. Texas Archeological Survey, Research Report 56, Palmetto Bend Reservoir Series 1. Austin.

Zavisch, Mrs. Harry, Jr.

1982 Letter to Harold Pendleton, Bureau of Reclamation, Three Rivers. September 17 . 


\author{
APPENDIX I \\ IDENTIFICATION OF WOOD SAMPLES FROM \\ TWO CEMETERIES IN THE CHOKE CANYON RESERVOIR
}

George R. Aliaga

Introduction

This report documents the composition of wood samples obtained from two cemeteries once located in the Choke Canyon Reservoir on the Frio River in southern Texas. These two cemeteries were recently moved in preparation for the filling of the reservoir.

The graves from the two cemeteries, Byrne Cemetery and Yarbrough Cemetery, date from approximately the $1850 \mathrm{~s}$ to the 1900s. The relocation of the cemeteries presented a splendid opportunity for the materials used in the construction of the caskets to be identified. From a total of twenty separate graves from the two cemeteries, wood samples obtained from the coffins were sent to the Anthropology Department at Texas A\&M University for compositional analysis, in order to determine the type of wood used in their construction.

\title{
Materials and Methods
}

The samples were initially screened by obtaining transverse surface views of the wood for tentative identification, by snapping along the transverse plane of the wood. To make a more permanent collection of the wood specimens from the 20 graves, samples of each specimen were charred. Samples no larger than $1 \times 1 \times 3 \mathrm{~cm}$ were removed from the larger specimen for charring. The samples were then carefully wrapped in aluminum foil to exclude as much oxygen as possible. Subsequently, the samples were slowly heated to $500^{\circ}-600^{\circ} \mathrm{C}$. The time required for complete charring of the samples varied. The larger the sample, the longer the time required for charring. Charring was considered complete when smoke no longer issued from the foil-wrapped samples. After removal from the oven, the samples were allowed to cool to room temperature before removing the foil. The samples were then snapped perpendicularly to the longitudinal plane to obtain a fresh cross-sectional surface for viewing (Leney and Castee 1 1975). To aid in viewing and in storage, the charred samples were glued to the inside tops of baby food jars with rubber cement.

The charred wood samples were viewed under a Wild Heerbrugg stereo microscope with direct top illumination from a fiberoptic illuminator. Additional1y, several specimens were selected at random to view in a JEOL 25 Scanning Electron Microscope operating at $5 \mathrm{KV}$.

Results and Discussion

In the early stages of this study, it was hypothesized that the wood from the coffins possibly might be composed of several species of angiosperms or 
gymnosperms which are endogenous to the floodplains of this region. Choke Canyon is located in the Tamaulipan Biotic Province, where thorny brush is the predominant vegetation. On the floodplain of the Nueces River in the northern portion of the province, live oak (Quercus virginiana Mi11) can be found, while the larger floodplain of the Rio Grande in addition supports elm (Ulmus crassifolia) (Blair 1950). We speculated that hardwood trees from adjacent Texas biotic provinces may have been used in the construction of the coffins. Consequently, other hardwood possibilities might include post oak (quercus stellata), black-jack oak (Quercus marilandica), and hickory (Carya buckleyi) from the Texan Biotic Province (Tharp 1926). Additionally, oak and elm could have been obtained from the Balconian Biotic Province which encompasses the Edwards Plateau, and is located directly to the north of the Tamaulipan Biotic Province.

Dering (1982) analyzed carbonized plant remains from archaeological sites in the Choke Canyon Reservoir area. The ages of these specimens ranged from 4300700 years. The carbonized samples analyzed were found to include several hardwoods: ash (Fraxinus sp.), willow (Salix sp.), live oak (Quercus virginiana), desert hackberry (Celtis pallida), mesquite (Prosopis glandulosa), and acacia (Acacia sp.). From the above information on the distribution of hardwoods in the area, there is the possibility that the wood used in the construction of the coffins could have been from the hardwoods regionally available.

As the wood samples yielded to identification, however, it became apparent that the coffins were being constructed from more easily workable and cheaper. woods. Even though several varieties of hardwoods were readily available, they were not used in the construction of the coffins from which the wood samples were obtained. This may be simply a matter of economics as to the choice of woods used to construct the coffins. Why use more expensive woods when cheaper and more easily worked woods were also readily available?

Texas supports the growth of several varieties of conifers, which includes species of pine, juniper, and cedar. Many of the varieties of pine found in Texas are also found throughout the southeastern pine forests, which extend from New Jersey to Texas (Josephson and Hair 1956). These species of pine include the long leaf pine, slash pine, loblolly, and short leaf pine (Gill and Dowling 1943).

In areas of dry sandy soils of the southeastern forests grow long leaf pine (Pinus palustris Mil1) and slash pine (Pinus elliottii Engelm), which are also the dominant species in this type of area of the forests. Areas with more abundant moisture support loblolly pine (Pinus taeda L). Along the Gulf coast $P$. elliottii occurs commonly today, while more inland species include $P$. taeda and shortleaf pine (Pinus echinata Mi11) (Josephson and Hair 1956).

Blair (1950) divided Texas into six biotic provinces, three of which have previously been mentioned in regard to the hardwoods commonly found. The most easterly biotic province is the Austroriparian which contains species of pine found in the southeastern forests. In this province, $P$. palustris dominates, while in the more westerly and northerly region of this province, $P$. taeda and P. echinata occur (Tharp 1926). P. taeda can be found growing in the Texan 
Biotic Province which is located directly to the west of the Austroriparian and extends to the east to the Balconian and to the Tamaulipan Biotic Provinces.

The charcoal botanical remains analyzed by Dering (1982) also included juniper (Juniperus sp.) which occurs today in the Choke Canyon area. Therefore, juniper may also have been a possible wood used in the construction of the coffins.

Table 2 summarizes the identification of the wood specimens from the various grave sites from the Byrne and Yarbrough Cemeteries. All of the wood samples presented the morphological characteristics common to members of the Family Pinaceae (Jane 1956; Panshin and Zeeuw 1970; Harlow 1975; White 1980; Baas 1982).

Al1 of the wood samples had resin ducts present to varying degrees. Therefore, the cedars along with juniper were eliminated as possibilities. This narrowed the choices to four genera which do have longitudinal resin canals: Pinus, Picea, Larix, and Pseudostuga.

Comparison of transverse sections of these four genera showed differences in the appearance of the early- and late-wood of the growth rings. In Picea (spruces) the change from early- to late-wood is gradual, while in Pseudostuga taxifolia (Douglas Fir) and Larix (Larch) the change is abrupt (Panshin and Zeeuw 1970). Certain members of the Pinaceae do show a more gradual change such as Scots pine (Pinus sylvestril $L$ ), yellow pine ( $P$ inus strobus $L$ ), and sugar pine (Pinus lambertiana Doug1), while the pitch pines also known as the hard pines show an abrupt transition from the early- to late-wood (Jane 1956). The hard pines include those species found in Texas already discussed. Consequently, from the early- and late-wood transitional appearance, Picea was ruled out as a possibility. Of the three remaining possible genera, Larch (Larix sp.) would be very difficult to differentiate from Pinus sp. With any degree of certainty from a transverse section alone. Larch was eliminated as a possibility by its geographic distribution. This conifer grows in a colder climate in areas of higher elevation of the northern hemisphere (Bailey 1978). Therefore, if the hypothesis is correct that the coffins are composed of locally available wood, then Larch can be ruled out as a possibility.

Douglas Fir (Pseudostuga taxifolia Poir) occurs primarily in western North America; however, this genus can be ruled out by characteristics observable in the transverse section. The epithelial cells which make up the resin ducts in the pines are thin and easily collapsable (Fig. 19), while the epithelial cells of the resin ducts in Pseutostuga are more easily visible since the cells have a much thicker cell wall, and are subsequently less likely to collapse or be torn (Jane 1950).

By eliminating the choices which do not meet all of the criteria dictated by the observed structure of the wood samples, and geographic distribution, the only genus left as a likely candidate for the type of wood used in the construction of the coffins is Pinus. Of the many species of pine to choose from, all can be eliminated except those varieties of the southern pine forests, the hard pines, primarily due to their local availability to the people living in the Choke Canyon area approximately 100 years ago. The possible species of 
TABLE 2. IDENTIFICATION OF WOOD SAMPLES

\begin{tabular}{|c|c|c|c|}
\hline Cemetery & Grave No. & Ident & ification \\
\hline \multirow[t]{17}{*}{ Byrne } & 1 & Pinus & $s p$ \\
\hline & 2 & Pinus & $s p$ \\
\hline & 3 & Pinus & $s p$ \\
\hline & 4 & Pinus & sp. \\
\hline & 5 & Pinus & sp. \\
\hline & 6 & Pinus & sp. \\
\hline & 7 & Pinus & sp. \\
\hline & 8 & Pinus & sp. \\
\hline & 9 & Pinus & sp. \\
\hline & 10 & Pinus & $\mathrm{sp}$. \\
\hline & 11 & Pinus & $s p$. \\
\hline & 12 & Pinus & sp. \\
\hline & 15 & Pinus & sp. \\
\hline & 16 & Pinus & sp. \\
\hline & 18 & Pinus. & sp. \\
\hline & 19 & Pinus & $s p$. \\
\hline & 20 & Pinus & sp. \\
\hline \multirow[t]{3}{*}{ Yarbrough } & 1 & Pinus & $s p$. \\
\hline & 4 & Pinus & $s p$. \\
\hline & 6 & Pinus & sp. \\
\hline
\end{tabular}




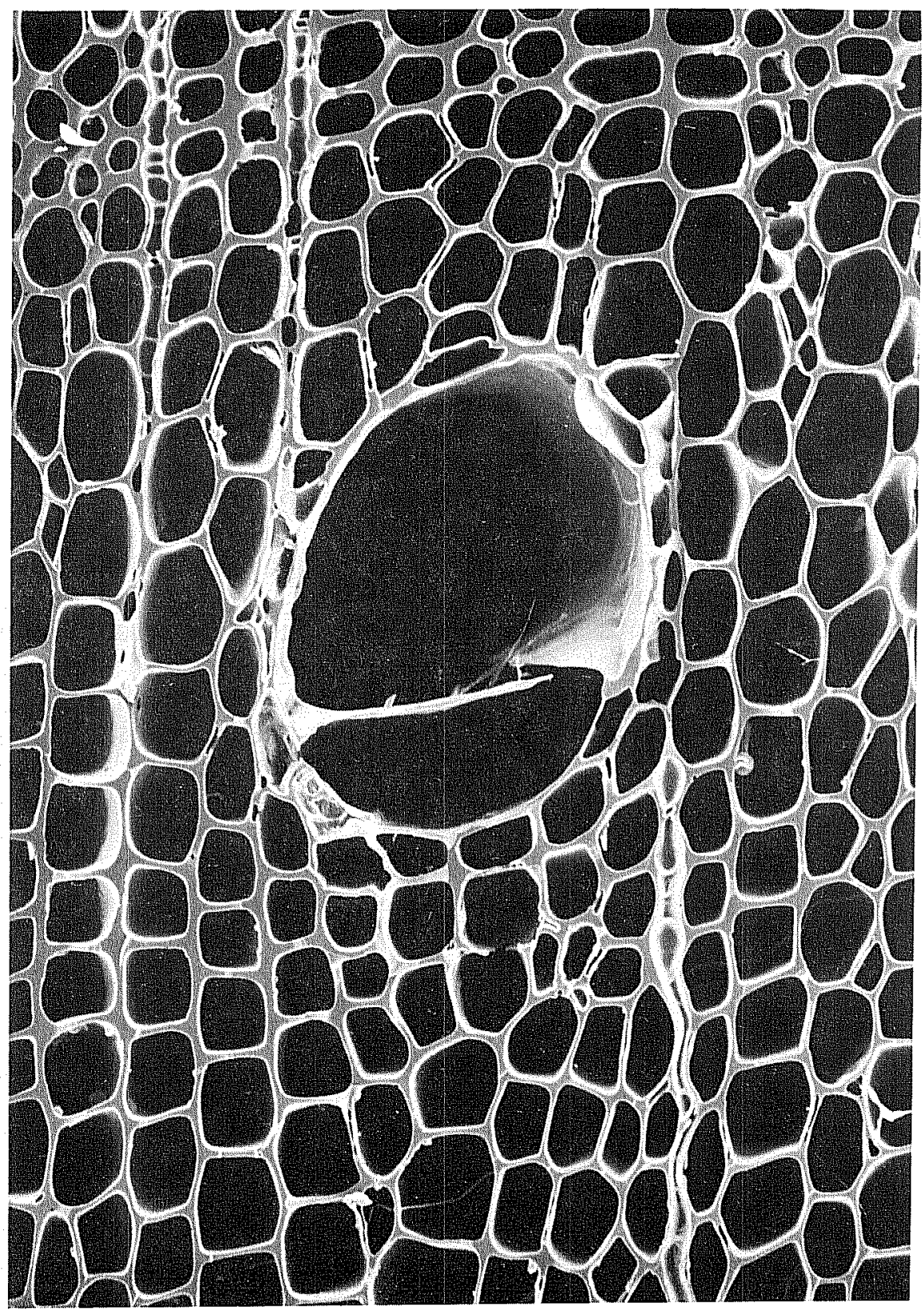

Figure 19. A Transverse Surface View of a wood Sample from Byrne Cemetery, Grave 2; X700. This micrograph shows the central resin duct with the thin-walled epithelial cells which have collapsed. Portions of three uniseriate rays are also visible. 
hard pines composing the coffins may include: Pinus palustris, Pinus elliottii, Pinus taeda, and Pinus echinata. The slash pine (Pinus elliottii) can be eliminated as a possibility, since the age of the wood samples precedes the time when slash pine grew in Texas. Slash pine has been introduced into Texas more recently than the age of the wood samples.

A11 of the wood samples upon charring had an appearance similar to the scanning electron micrographs (Figs. 19, 20, and 21). Figure 20 is of a sample from Byrne Cemetery, Grave 2, and shows the typical transverse morphological appearance of pine. There is an abrupt change between early- and late-wood, transverse rays are typically uniseriate, and there is an abundance of resin ducts. The resin ducts are surrounded by thin walled easily collapsable epithelial cells, as shown in Figure 19. Figure 21 is a micrograph of a wood sample from Yarbrough Cemetery, Grave 1. This specimen was photographed at a slightly oblique angle to the vertical axis of the transverse plain. The abrupt change between early- and late-wood can be seen, along with three resin ducts. One entire growing season can be seen.

Many of the wood samples presented a difficulty upon the breaking of the specimen to obtain a clean transverse surface for viewing. A common problem was the presence of plant roots which grew throughout the wood, and often interferred with a "clean" break of the wood. Also much of the wood showed varying degrees of water damage and insect damage. After charring, many of the specimens would often not produce a complete break across the grain; often, the grain would separate one from another, and the break would either not be clean and straight across the grain, or the whole sample would fall apart along the lines of the grain. All the samples charred and observed did show, however, the morphological characteristics as shown in Figures 19-21.

Summary

Because of a lack of a suitable pine reference collection, the wood samples could not be identified with any degree of certainty to species. At best, pine wood is very difficult to speciate even with a good reference collection. The southern pines, longleaf, shortleaf, loblolly, and the others are not separated by wood structure alone (Harlow 1975). As I have seen from various wood keys of the conifers, the southern pines are placed together under the general heading of hard pines, and are not differentiated by wood structure. From the geographic evidence of the various pines, however, along with the appearance of the transverse surface of the wood samples, the wood composing the coffin samples was narrowed down to possibly three varieties of southern pine: Pinus palustris, Pinus taeda, and Pinus echinata.

\section{References cited}

Baas, P.

1982 New Perspectives in Wood Anatomy. Martinus Nijhoff/Dr. W. Junk Publishers, Boston. 


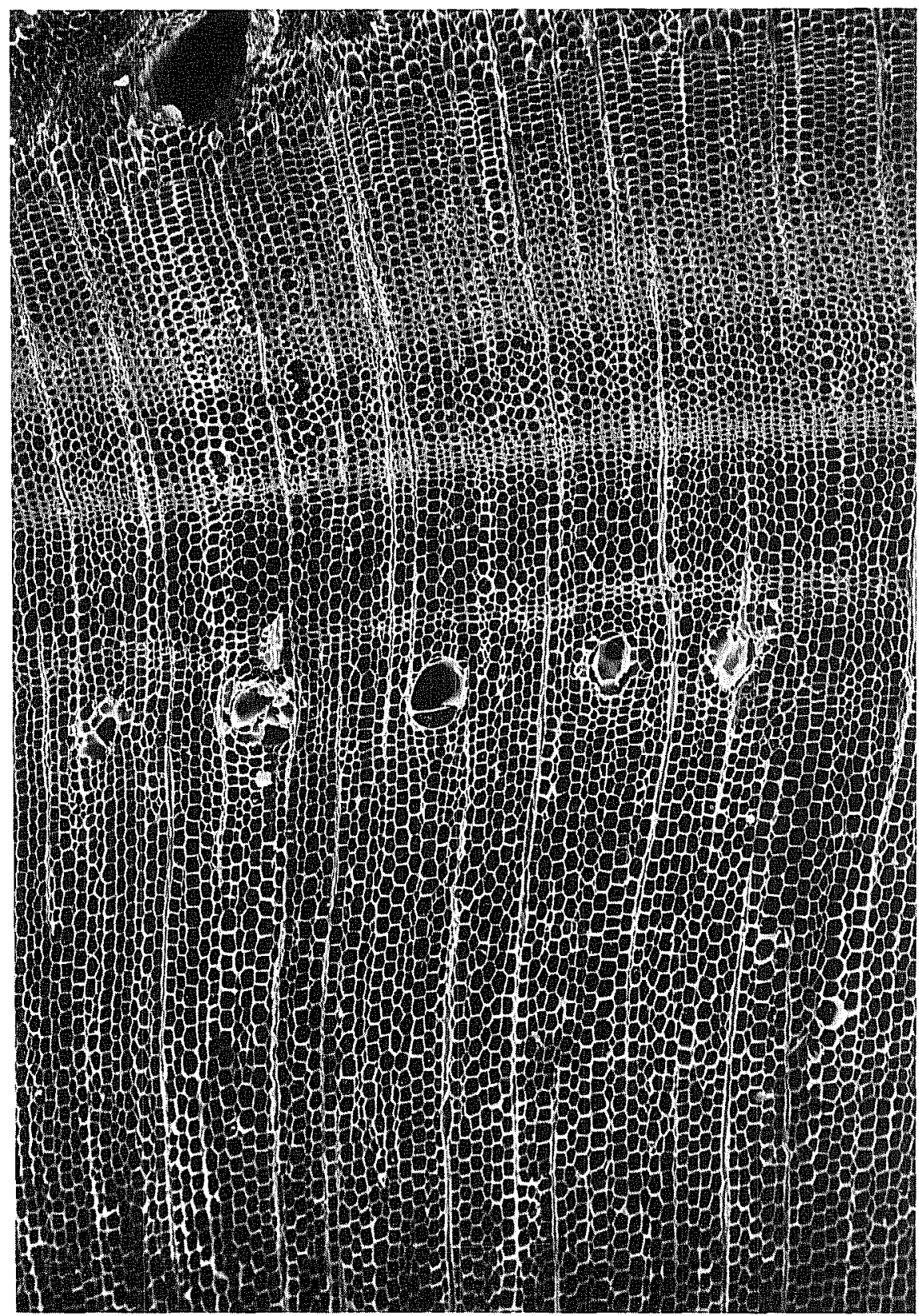

Figure 20. A Transverse Surface View of a wood Sample from Byrne Cemetery, Grave 2; X100. This micrograph shows the characteristic arrangement of the tracheids into early- and late-wood, with an abrupt transition between the two. Also present are the characteristic resin ducts of the Pinaceae. The resin ducts are surrounded by thin-walled epithelial cells which have collapsed and torn, this is indicative of certain types of pine (see text for explanation). 


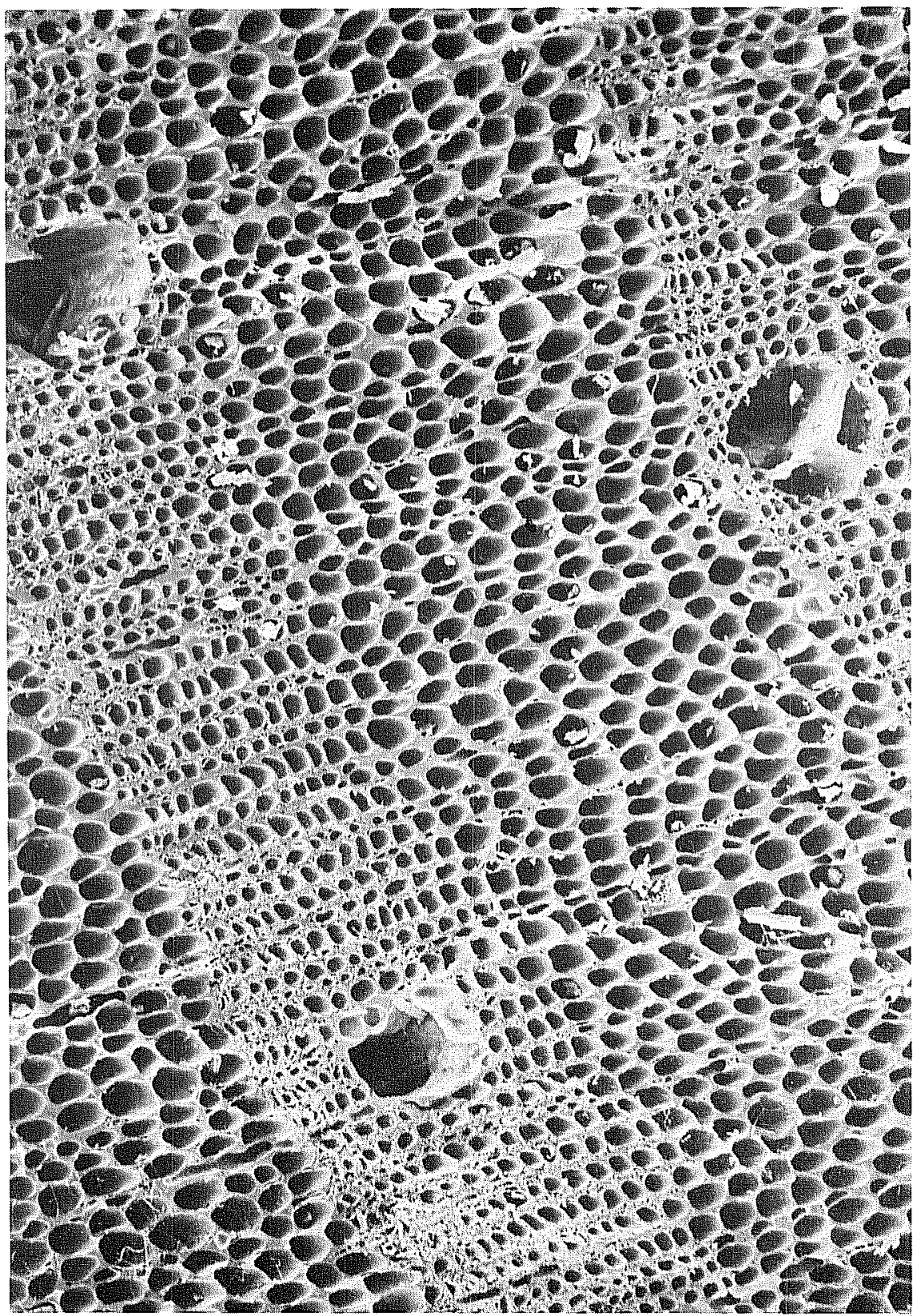

Figure 21. A Transverse Surface View of a wood Sample from Yarbrough Cemetery, Grave 1, X150. This micrograph shows one complete growing season, the transition between early- and late-wood is abrupt. Also visible are three resin ducts. 
Bailey, L. H.

1978 The Cultivated Conifers in North America. Allanheld, 0smun/ Universe Books, New York.

Blair, W. F.

1950 The Biotic Provinces of Texas. The Texas Journal of Science 2:93-117.

Dering, $P$.

1982 Analysis of Carbonized Botanical Remains from the Choke Canyon Reservoir Area. In Archaeological Investigations at Choke Canyon Reservoir, South Texas: The Phase I Findings, by G. D. Ha 11, S. L. Black, and C. Graves:518-530. Center for Archaeological Research. The University of Texas at San Antonio, Choke Canyon Series 5.

Gill, T. and E. C. Dowling

1943 The Forestry Directory. The American Tree Association, Washington, D.C.

Harlow, W. M.

1975 Inside wood/Masterpiece of Nature. The American Forestry Association, Washington, D.C.

Jane, F. W.

1956 The Structure of Wood. Macmillan Co., New York.

Josephson, H. R. and D. Hair

1956 The United States. In A world Geography of Forest Resources, edited by H. G. Stephen, J. K. Wright, and E. C. Teclaff:165166. The Ronold Press Co., New York.

Leney, L. and R. W. Castee

1975 Simplified Procedure for Examining Charcoal Specimens for Identification. Journal of Archaeological Science 2:153-159.

Panshin, A. J. and C. Zeeuw

1970 Textbook of Wood Technology. McGraw-Hil1 Book Co., New York.

Tharp, B. C.

1926 Structure of Texas Vegetation East of the 98th Meridian. University of Texas Bulletin 2606:1-100. 
68

White, M. S.

1980 Wood Identification Handbook/Commercial Woods of the United States. Charles Scribner's Sons, New York. 


\title{
APPENDIX II
}

\section{ANALYSIS OF RELIGIOUS MEDAL}

\author{
Richard E. Ahlborn
}

The following analysis of the religious medal from the grave of Miss Eliza Byrne (Fig. 16,b) has been graciously provided by Richard E. Ahlborn, Curator, Division of Community Life of the National Museum of American History, Smithsonian Institution, Washington, D.C.:

Here is my reading of the inscription (read periods as pellets):

Obverse, circumference: IOEIVS.IN.OBITV.NPO.PRAE. SENT IA.MVNIAMVRo

left side: CRUX S.PATRIS

right side: BENEDICTI

below: ?XS.M.CASINO/MDCCCLXXX

Reverse, circumference: S.M.Q.L.I.V.B (PAX) V.R.S.N.S.M.V

circles: C S P B (see left/right sides of obverse)

cross: C S S M L (down), ND S MD (across)

The translation for the Latin inscription C S P B is "Cross of Holy Father Benedict." We can see the long (black) habit, book of Rules, hand cross and attributes (crow with bread and a cup or chalice with a snake) on the obverse. The place and date of origin are given below:

Monte Casino, 1880.

The cross' intersecting initials read, "Crux Sacra Sit Mihi Lux, Non Draco Sit Mini Dux." The translation for this is, "May the Holy cross be my light, may not the dragon (demon) be my guide." The cross with Latin for "peace" above it (reverse), recalls an early Christian, Near Eastern type, as does the cap.

Benedict was an abbot who founded the Benedictine Order, and died at Monte Casino in 543. The design, facial loop (not cross-set) and date all support a late 19th-century manufacture. 

APPENDIX III

GLOSSARY

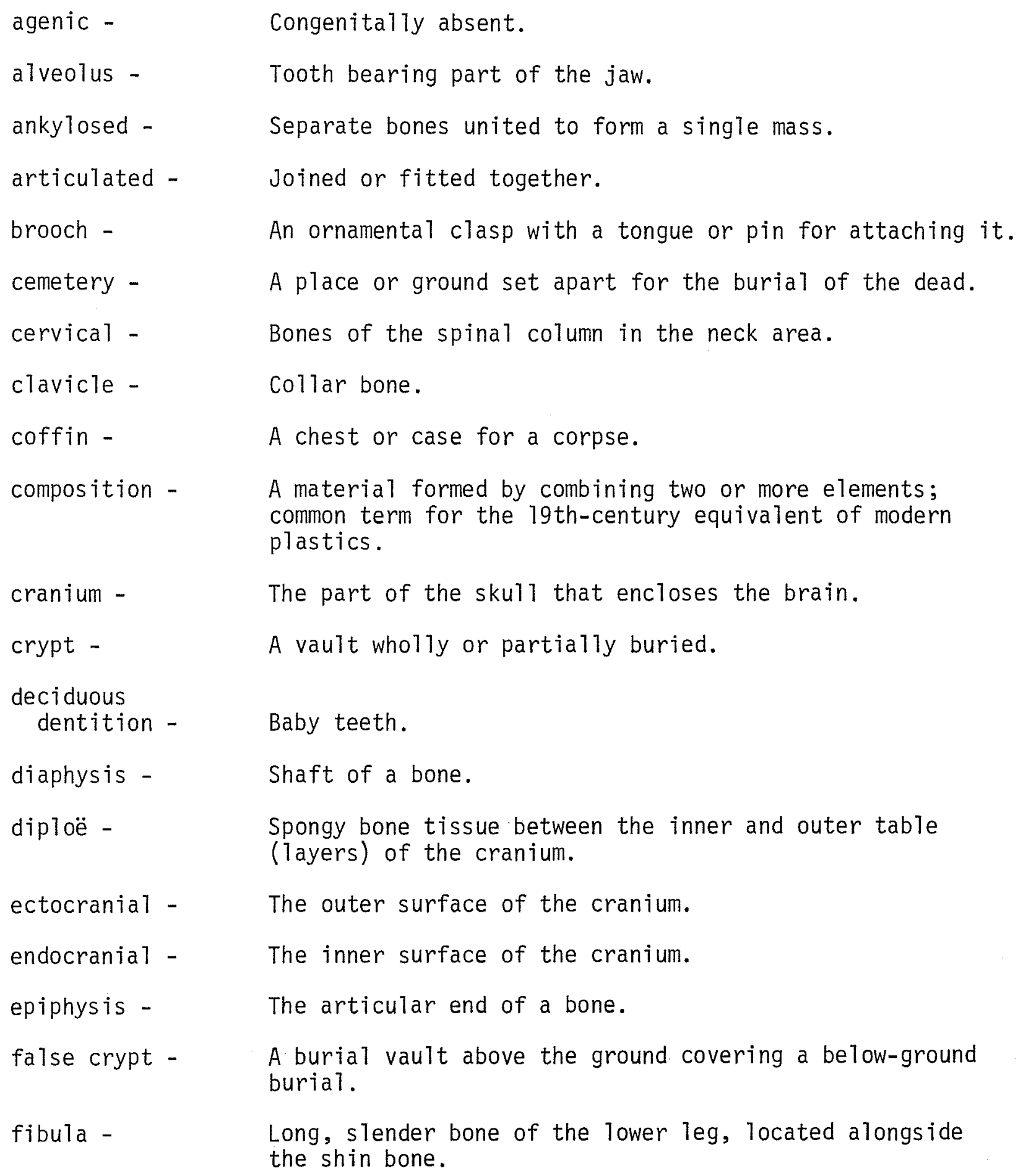




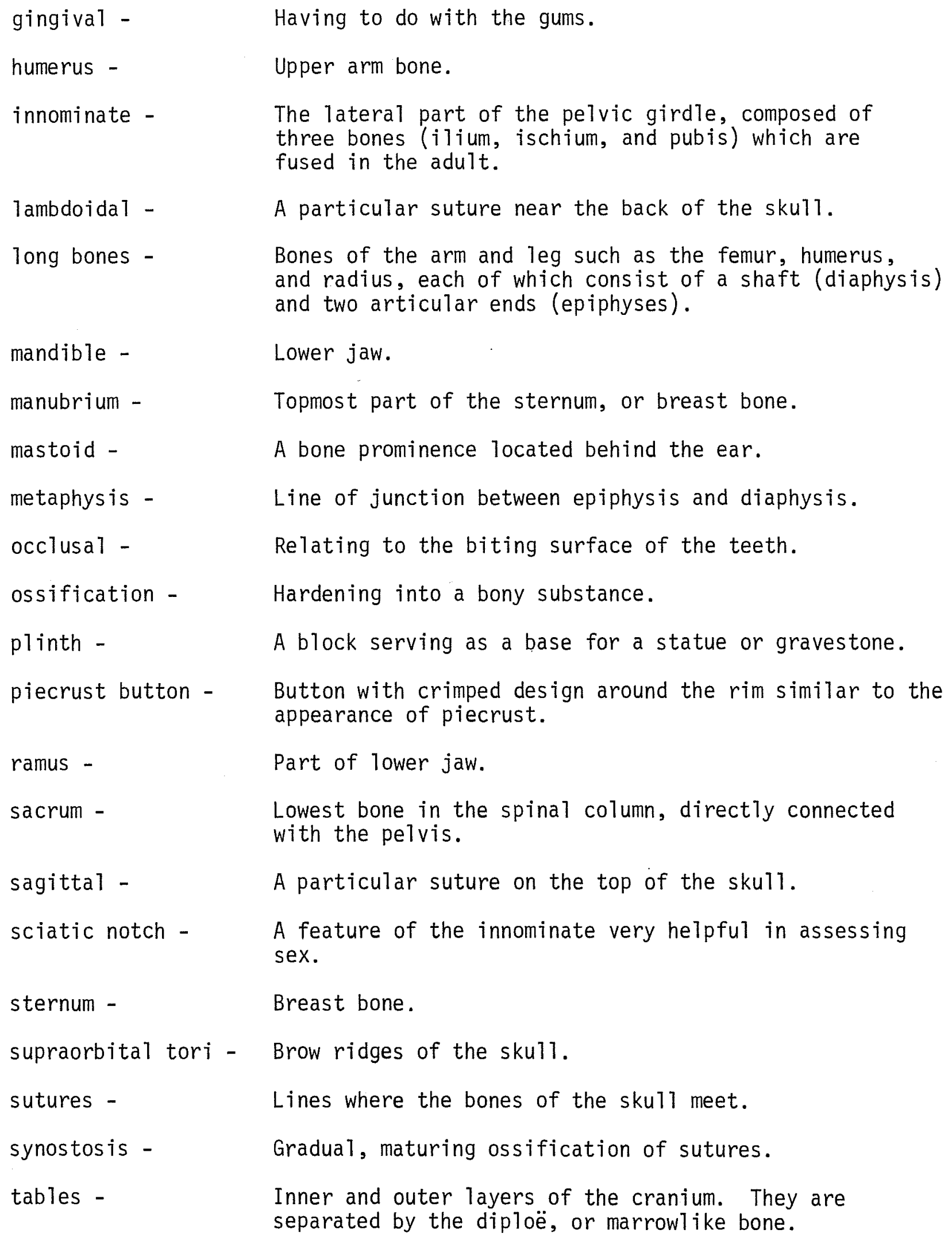


thoracic vertebrae - Those between the neck (cervical) and the lower back (7umbar).

tibia -

vertebrae -
Shin bone.

Bones of the spinal column. 
